\title{
2013 Survey Assessments and Analysis of Fish, Macroinvertebrates and Herpetofauna in the Otter Creek Coal Tracts Area of Powder River County
}

\author{
Prepared for:
}

\section{Pat Farmer, Project Manager/Director}

Westech Environmental Services

Helena Field Office

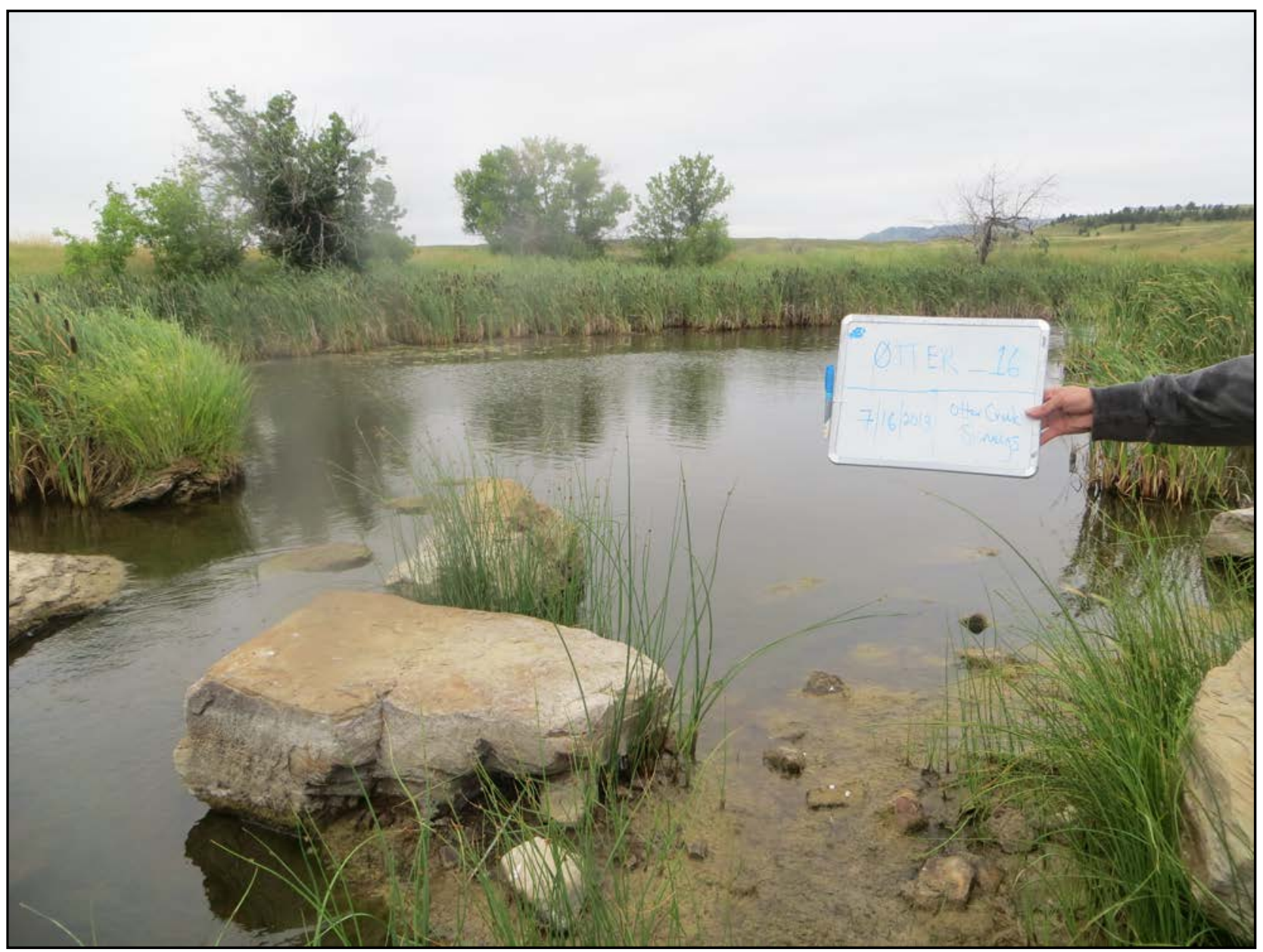

Prepared by:

David Stagliano, Aquatic Ecologist

Montana Natural Heritage Program

January 2014

a cooperative program of the

Montana State Library and the University of Montana 


\section{Executive Summary}

We summarize the third year of baseline surveys for aquatic communities and herpetofauna in the Otter Creek coal tracts area. Project goals remain the same: 1) to continue standardized surveys and collecting baseline information on the aquatic communities prior to coal development, 2) to seasonally assess aquatic community integrity and condition with key indicators recorded on-site and comparing these against biotic thresholds of reference condition standards and testing treatment differences. These 2013 aquatic community data represent the third year of pre-coal development (i.e. pre-impact $\mathrm{BACl}$, Before After Control Impact design) conditions at the local reach scale.

Habitat assessments, herpetofauna, macroinvertebrate and fish surveys were performed during seasonally similar dates at the same sites visited in 2011 and 2012: four main-stem Otter Creek reaches (Control, Impact $\{2\}$ and Downstream) and three tributary streams. In total, we performed 15 fish surveys during 2013. Thirteen macroinvertebrate samples were collected during the visits; neither survey was conducted at Threemile Creek during any season due to lack of surface water present. All stream reaches were visually and aurally surveyed for amphibians and reptiles during all visits. Biological community integrity was calculated for 15 fish surveys using Fish Integrated Biotic Indices (IBI's) and Observed/Expected Models (O/E), while the 13 macroinvertebrate samples were assessed with Montana DEQ's multi-metric indices (MT MMI).

Habitat Evaluations. Of the seven reaches evaluated in the study area, we found three in Proper Functioning Condition (PFC) with a stable trend; three were Functional at Risk (FAR) and one nonfunctional (NF). Sites ranked FAR or NF due to stream habitat structurally degraded by cattle (Home \{Otter_1A\}, Tenmile $\{$ Otter_23\} and Threemile $\{$ Otter_3m\} Creeks) or stream manipulation (Otter Creek \#2). Highest site integrity scores using both the BLM Habitat and PFC Assessment methods were recorded at Otter Creek sites \#22 and JT, Denson Control and Trusler reaches, respectively. Sites with lower habitat scores are inversely correlated with high livestock use indices (CPI values). Specific Conductivity measurements recorded at all Otter Creek mainstem sites across all seasons

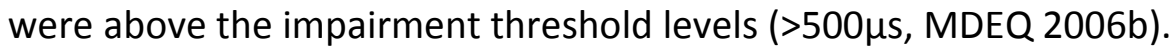

Macroinvertebrate Communities: Overall, 78 unique macroinvertebrate taxa were reported in 2013 from 13 macroinvertebrate assessment samples. One mayfly species of concern (MTSOC), Caenis youngi was collected at the Otter Creek sites \#16 and \#22. Highest taxa richness (37 spp.) was reported at Otter JT during the fall visit, while overall macroinvertebrate richness per site was 29.1 taxa, slightly less than 2012 or 2011. Using the MTDEQ multimetric index (MMI), four of the five sites (11 of 13 samples) were ranked non-impaired (good biological integrity), while two samples from Tenmile (Otter_23) and Home Creek (Otter_1A) were ranked impaired. MMI scores in 2013 were not significantly different than 2012 scores $(p>0.4)$. Sites that maintained flowing water connectivity scored higher with the MMI than sites with interrupted pool areas. Overall, mainstem sites evaluated in the Otter Creek study had significantly different MMI scores than those in the tributaries (ANOVA, $p$ <0.01). MMls did not significantly differ between Otter Creek mainstem Pre-Impact Control, Impact or Downstream Sites (T-test, $\mathrm{p}>0.05$ ), despite fish communities reflecting a downstream decrease in biotic integrity.

Fish Communities. Overall, ten fish species (five native/five introduced) were identified from 16,215 individuals collected during 15 surveys. The brassy minnow, a potential species of concern (PSOC), 
was collected at five sites during all 15 surveys. Average total fish species per Otter Creek mainstem site across all seasons was 6.7 ( $\pm 0.5 \mathrm{SE}$ ), a slight decrease from 2012 (7.0). Brassy minnows had the highest site occupancy rate of $100 \%$ (15 of 15 visits) followed by lake chubs, fathead minnows, and white suckers at $80 \%$ and $67 \%$ (12 and 10 out of 15 visits), respectively. Lake chubs edged out fathead minnows in 2013 to account for the highest proportion of total individuals collected at $28 \%$. The most diverse fish site in the study area was Otter Creek \#16 with nine species, while sites with the highest \% of native species were Otter Creek JT (five spp.) and Home Creek (two native spp.). Using Montana's Prairie Fish Integrity Biotic Index (IBI), nine of the 15 fish visits ranked non-impaired (good integrity), five were slightly-moderately impaired and one was ranked poor. As seen in 2012, fish IBI's decreased going downstream in the Otter Creek mainstem and seasonally with lowest scores recorded during the fall. In 2013, fish IBI scores of the Control Site were not significantly different than either the Impact $(p=0.089)$ or the Downstream site $(p=0.24)$ using Student T-tests, but the $O / E$ scores of the Control were significantly different than Impact sites $(p=0.02)$ and the Downstream site $(p=0.04)$. The $O / E$ scores agreed with the $|B|$ in most cases, except Otter_2 summer, where the O/E showed non-impairment (0.91), but the IBI score (54) indicated impaired fish integrity. Further evaluations into the relationship of the $\mathrm{O} / \mathrm{E}$ to the $\mathrm{IBI}$ are needed for non-natives. A fish anomaly index recorded the highest scores at the Impact sites, especially increasing at Otter \#2 in 2013

Amphibian and Reptile Incidentals. Nine herpetofauna species were observed or collected in conjunction with the assessment surveys. Of the four amphibian species; the Northern Leopard Frog (Lithobates pipiens) had the highest site occupancy, occurring at four of seven sites, followed by the Woodhouse's Toad (Anaxyurus woodhousii) and Boreal Chorus Frog (Pseudacris maculata) both recorded at three sites. The Boreal Chorus Frog was detected vocally calling at two sites during the spring visits. Tiger salamanders (Ambystoma tigrinum) continue to use Home Creek (Otter_1A) as a breeding area, as evidenced by larvae captured while seining during summer visits. We also recorded five reptile species (in order of site occurrence): Painted Turtle (Chrysemys picta), Snapping Turtle (Chelydra serpentina) (a MTSOC), Western Rattlesnake (Crotalus viridis), Gopher snake (Pituophis catenifer) and Terrestrial Garter Snake (Thamnophis elegans).

Conclusions. Otter Creek mainstem reaches within the area proposed for the future mine site (i.e. Impact Zone sites) continue to show higher impairment levels in biological integrity than the Control or Downstream reaches. Spatial and temporal patterns of aquatic community composition and biotic integrity were similar between the 2013 and 2012 surveys, with a notable increase in the percentage of non-native fish occurring across most sites, especially in the fall. Biotic integrity of the Otter Creek upstream control reach remains higher than impact or downstream reaches (based on fish), but has decreased since 2011. Macroinvertebrates show no discernible pattern of integrity spatially, but temporally are reporting higher integrity scores during the spring samples. Fish communities have reassembled themselves since the high water of 2011 with the addition of the golden shiner to three sites in 2012, but they were only reported at one site in 2013. The high density and biomass of fish captured below Truslers Ranch road crossing, 20,000 fish per $300 \mathrm{~m}$ in fall 2011, has dispersed to other sections and now averages 1,900 fish per $300 \mathrm{~m}$, but still has a high percentage of fish anomalies (lesions and parasites- yellow grub and anchorworm). Fish anomaly scores are significantly higher at the Impact Zone sites than reported at the other reaches. 


\section{TABLE OF CONTENTS}

INTRODUCTION

METHODS

Study Area

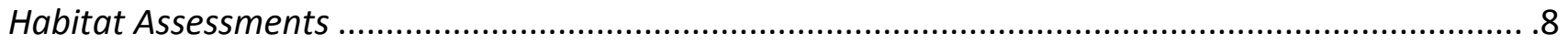

Macroinvertebrate Community Surveys............................................................................... .9

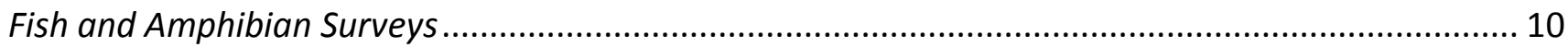

RESULTS

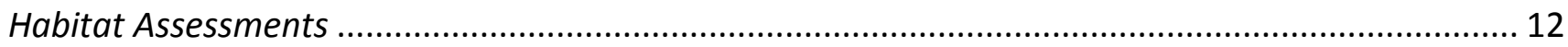

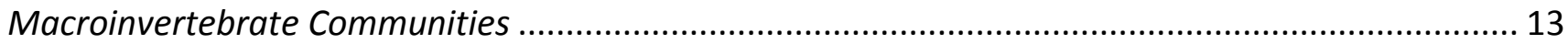

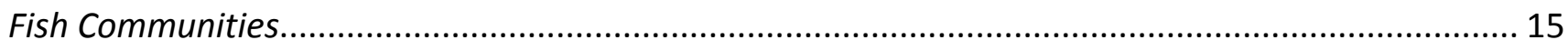

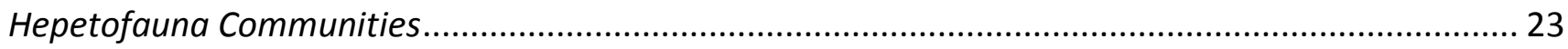

CONCLUSIONS

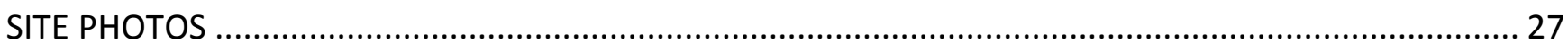

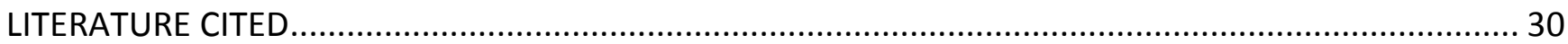

APPENDIX A. Fish data and IBI metric calculations collected from Otter Creek Project Sites

APPENDIX B. Macroinvertebate taxa list, abundance and metrics for the 13 collection sites

APPENDIX C. Stream Habitat and Water Quality Parameters measured for Otter Creek sites.

\section{List of Figures}

Figure 1. USGS gage data for Otter Creek at Ashland 2012 and 2013...............................................

Figure 2. Macroinvertebrate D-net Sampling procedure ..................................................................

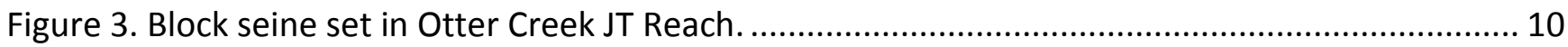

Figure 4. Photo of a structurally cattle-damaged, functional-at-risk (FAR) stream reach ..................... 11

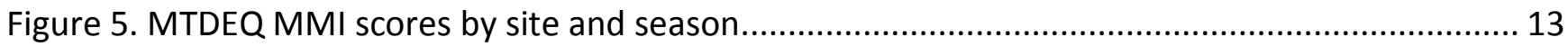

Figure 6. Average macroinvertebrate MMI scores by site type ........................................................ 14

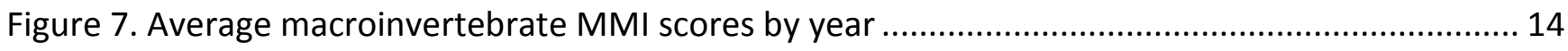

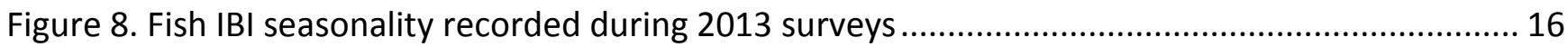

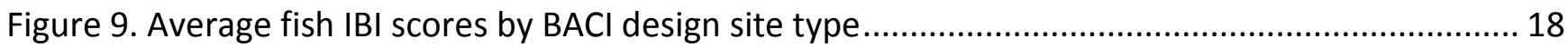

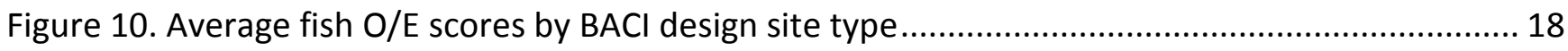

Figure 11. Average fish IBI scores by treatment type and year.......................................................... 19

Figure 12. Comparison of the Fish IBI and O/E scores between sites and season ................................ 19

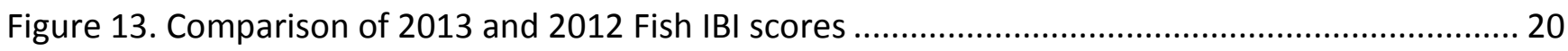

Figure 14. Comparison of 2013 and 2012 Native Fish Percentage (\%)............................................. 21

Figure 15. Fish anomaly scores in 2013, 2012 and 2011 by sites and seasons. .................................. 21

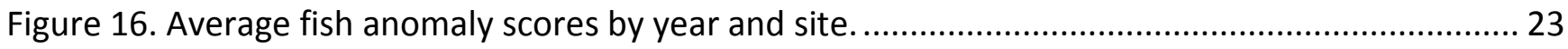

Figure 17. Snapping Turtle and Terrestrial Garter Snake from Otter Creek \#22 and JT.................................. 24 


\section{List of Tables}

Table 1. Otter Creek Study site GPS locations of reach

Table 2. Impairment determinations from the MMI and O/E (RIVPACS) models ..............................9

Table 3. Fish metrics and classification of fish species captured in the study area........................... 11

Table 4. Macroinvertebrate sample characteristics and metrics used for the DEQ MMI ...................13

Table 5. Fish abundance, IBI and O/E scores for the 12 surveys reporting fish ................................ 16

Table 6. Species of vertebrates collected during the aquatic surveys in 2013............................... 24

\section{Acknowledgements}

We would like to thank Pat Farmer of Westech Environmental Services of Helena for funding this project under agreement \# L13-534. Editorial review and comments that improved this report were provided by Linda Vance, Pat Farmer and Gary Carnefix. Field work coordination, landowner contacts and logistics were greatly expedited by Carl Lenz and Heidi Kaiser (Hydrometrics, Inc.). Field survey assistance provided by Phil Sawatzski, Kyla Zaret and Sara Owen (MTNHP) was invaluable.

All photos in the report were taken by MTNHP personnel, unless otherwise noted 


\section{Introduction}

The Otter Creek basin southeast of Ashland, Montana is currently undergoing exploration for a large, open-pit coal mine. Baseline data on the condition of the watershed prior to coal mine development (pre-impact) is essential to determine what effects the coal extraction might have on the fish and wildlife in, and downstream of, the effected extraction area (post-impact). Initial evaluations of the aquatic communities determined that no Federally Listed species under the Endangered Species Act would be affected in the coal tracts area (BLM 2002), but this Environmental Assessment did not take into account the presence of Montana Species of Concern (MTSOC) or other ecologically sensitive native species assemblages. Despite numerous projects undertaken to document and monitor biological communities in CBNG areas of the Powder and Tongue River watersheds (Confluence Consulting Inc. 2004; Stagliano 2006; Davis et al. 2009; Maxell 2009; Petersen et al. 2009, 2010; Farag et al. 2010; Stagliano 2011), large gaps still exist in basic baseline surveys for macroinvertebrates, fish, and herpetofauna in the Otter Creek basin. Fish communities have been documented to be seasonally variable in prairie streams (Bramblett and Fausch 1991, Lohr and Fausch 1997, Matthews 1998), thus sampling across all seasons in multiple years is a good strategy to document baseline community differences. Over three years of stream monitoring, Otter Creek's annual discharge statistics reported a historically "wet" year in 2011 (14.6 cfs), a "normal" water year in 2012 (8.6 cfs), though this was still almost two times higher than the 35 year average $(4.7 \mathrm{cfs})$, and a slightly more normal discharge year in 2013 (7.7 cfs) (USGS 2013). Highly variable seasonal discharge patterns are common for Otter Creek and other perennial prairie streams in Montana. Water availability in many small prairie streams that constitute the Intermittent Prairie Stream ecological system (Stagliano 2005) is highly variable, and these streams may have downstream connectivity early in the season for potential fish spawning and nursery areas (Matthews et al. 1988, Bramblett et al. 2005) or no fish colonization at all in dry years and become isolated pools important areas for amphibian breeding and rearing (Stagliano 2011). Identifying spatial and temporal baseline communities and conditions in streams of the coal tracts area (i.e., presence of fish, macroinvertebrate, and herpetofauna) prior to coal development is essential to understanding and potentially mitigating impacts to habitats and species during and after coal extraction.

\section{Methods}

\section{Study Area}

Pre-impact baseline sampling sites visited in 2013 were the same reaches designated in 2011 (Stagliano 2012). These sites are representative of the range of stream types found in the Otter Creek Coal Tracts project area: Ephemeral, Intermittent and Perennial Prairie Streams. Four mainstem Otter Creek reaches (control, impact $\{2\}$ and downstream) and three tributaries 
coinciding with established surface water quality stations were visited seasonally (May, July, October) (Table 1). Threemile Creek remained dry during all visits and no fish or macroinvertebrate surveys were conducted (see Site Photos). Seasonal site visits were timed with 2011 and 2012 dates, and we coordinated sampling with baseflow discharge levels, which was easily accomplished in the spring of 2013 compared to 2012, because there was largely no spring, high discharge pulse (Figure 1).

Table 1. Otter Creek Coal Study Site Characteristics. GPS Locations at the top (T) and bottom (B) of the assessment reach. Aquatic Ecological System (AES) code defined in text followed Stagliano (2005).

\begin{tabular}{|c|c|c|c|c|c|c|c|}
\hline Site Code & Site Name & Type & AES code & Latitude & Longitude & $\begin{array}{l}\text { Elev } \\
(\mathrm{m})\end{array}$ & Comment \\
\hline $\begin{array}{l}\text { Otter_23 } \\
\text { Otter_23 }\end{array}$ & $\begin{array}{l}\text { Tenmile Creek (T) } \\
\text { Tenmile Creek (B) }\end{array}$ & $\begin{array}{l}\text { Control } \\
\text { Control }\end{array}$ & $\begin{array}{l}\text { D005/E005 } \\
\text { D005/E005 }\end{array}$ & $\begin{array}{l}45.43409 \\
45.43465\end{array}$ & $\begin{array}{l}-106.13403 \\
-106.13253\end{array}$ & $\begin{array}{l}961 \\
958\end{array}$ & $\begin{array}{l}\text { Dry during May and July, } \\
\text { small pool during Oct. visit }\end{array}$ \\
\hline $\begin{array}{l}\text { Otter_22 } \\
\text { Otter_22 }\end{array}$ & $\begin{array}{l}\text { Otter Creek } 22 \text { (T) } \\
\text { Otter Creek } 22 \text { (B) }\end{array}$ & $\begin{array}{l}\text { Control } \\
\text { Control }\end{array}$ & $\begin{array}{l}\text { D005/C005 } \\
\text { D005/C005 }\end{array}$ & $\begin{array}{l}45.43035 \\
45.43274 \\
\end{array}$ & $\begin{array}{l}-106.14428 \\
-106.14366 \\
\end{array}$ & $\begin{array}{l}951 \\
948\end{array}$ & $\begin{array}{l}\text { Top of reach } \sim 60 \mathrm{~m} \text { below } \\
\text { Tenmile Creek road, } \\
\text { proceeded } 300 \mathrm{~m} \\
\text { downstream }\end{array}$ \\
\hline $\begin{array}{l}\text { Otter_16 } \\
\text { Otter_16 }\end{array}$ & $\begin{array}{l}\text { Otter Creek } 16 \text { (T) } \\
\text { Otter Creek } 16 \text { (B) }\end{array}$ & $\begin{array}{l}\text { Impact } \\
\text { Impact }\end{array}$ & $\begin{array}{l}\mathrm{CO05} \\
\mathrm{C005}\end{array}$ & $\begin{array}{l}45.48514 \\
45.48365\end{array}$ & $\begin{array}{l}-106.16487 \\
-106.16725\end{array}$ & $\begin{array}{l}938 \\
937\end{array}$ & $\begin{array}{c}\text { Top of reach } \sim 60 \mathrm{~m} \text { above } \\
\text { the stream crossing and } \\
240 \mathrm{~m} \text { below }\end{array}$ \\
\hline $\begin{array}{l}\text { Otter_3m } \\
\text { Otter_3m }\end{array}$ & $\begin{array}{l}\text { Threemile Creek (T) } \\
\text { Threemile Creek (B) }\end{array}$ & $\begin{array}{l}\text { Impact } \\
\text { Impact }\end{array}$ & $\begin{array}{l}\text { E005 } \\
\text { E005 }\end{array}$ & $\begin{array}{l}45.51054 \\
45.50955 \\
\end{array}$ & $\begin{array}{l}-106.16288 \\
-106.16960 \\
\end{array}$ & $\begin{array}{l}933 \\
928 \\
\end{array}$ & Dry during all visits \\
\hline $\begin{array}{l}\text { Otter_2 } \\
\text { Otter_2 }\end{array}$ & $\begin{array}{l}\text { Otter Creek } 2(\mathrm{~T}) \\
\text { Otter Creek } 2 \text { (B) }\end{array}$ & $\begin{array}{l}\text { Impact } \\
\text { Impact }\end{array}$ & $\begin{array}{l}\mathrm{COO5} \\
\mathrm{CO05}\end{array}$ & $\begin{array}{r}45.50475 \\
45.50561 \\
\end{array}$ & $\begin{array}{l}-106.17493 \\
-106.17561 \\
\end{array}$ & $\begin{array}{l}929 \\
928 \\
\end{array}$ & $\begin{array}{l}\text { Site surveyed for fish } \\
\text { during all visits, } \\
\text { downstream of road } \\
\text { crossing }\end{array}$ \\
\hline $\begin{array}{l}\text { Otter_JT } \\
\text { Otter_JT }\end{array}$ & $\begin{array}{l}\text { Otter Creek JT (T) } \\
\text { Otter Creek JT (B) }\end{array}$ & $\begin{array}{l}\text { Down } \\
\text { Down }\end{array}$ & $\begin{array}{l}\mathrm{CO05} \\
\mathrm{CO05} \\
\end{array}$ & $\begin{array}{r}45.55675 \\
45.55782 \\
\end{array}$ & $\begin{array}{l}-106.21798 \\
-106.21770 \\
\end{array}$ & $\begin{array}{l}910 \\
909 \\
\end{array}$ & $\begin{array}{l}\text { Top of reach } \sim 80 \mathrm{~m} \text { below } \\
\text { ranch road culvert to } \\
300 \mathrm{~m} \text { downstream }\end{array}$ \\
\hline $\begin{array}{l}\text { Otter_1A } \\
\text { Otter_1A }\end{array}$ & $\begin{array}{l}\text { Home Creek (B) } \\
\text { Home Creek (T) }\end{array}$ & $\begin{array}{l}\text { Down } \\
\text { Down }\end{array}$ & $\begin{array}{l}\text { D005/E005 } \\
\text { D005/E005 }\end{array}$ & $\begin{array}{l}45.54483 \\
45.54422\end{array}$ & $\begin{array}{l}-106.18717 \\
-106.18947\end{array}$ & $\begin{array}{l}952 \\
950\end{array}$ & $\begin{array}{l}\text { Bottom of reach } \sim 500 \mathrm{~m} \\
\text { above road crossing, then } \\
300 \mathrm{~m} \text { upstream }\end{array}$ \\
\hline
\end{tabular}

Average yearly discharge for 2013 was 7.7 cfs versus 14.6 cfs in 2011 and 3.9 cfs in 2010, which is still substantially higher than the 35 year average of 4.7 cfs (USGS 2012, 2013). Discharge during the 2013 May sampling visit (7 cfs) was similar to 2012, but only one third that of 2011 (19 cfs), while the summer and fall visits were closer to average baseflows at 2.5 and $5 \mathrm{cfs}$, respectively. Discharge patterns of the 2013 hydrograph were very different than in 2012, with virtually no early spring pulse and a very high rainfall-related pulse in late-May (Figure 1). During this fall's survey, we sampled during a day-long, wet snow/sleet storm that caused Otter Creek to increase by 2 cfs overnight. Habitat assessments, herpetofauna, macroinvertebrate and fish surveys were 
performed during seasonally similar dates at the same sites visited in 2011 and 2012 . All stream reaches were visually and aurally surveyed for amphibians and reptiles during all visits.

Figure 1. Discharge reported at the USGS gage in Ashland, MT for 2012 (top) and 2013 (bottom). Arrows indicate date of sampling visit.

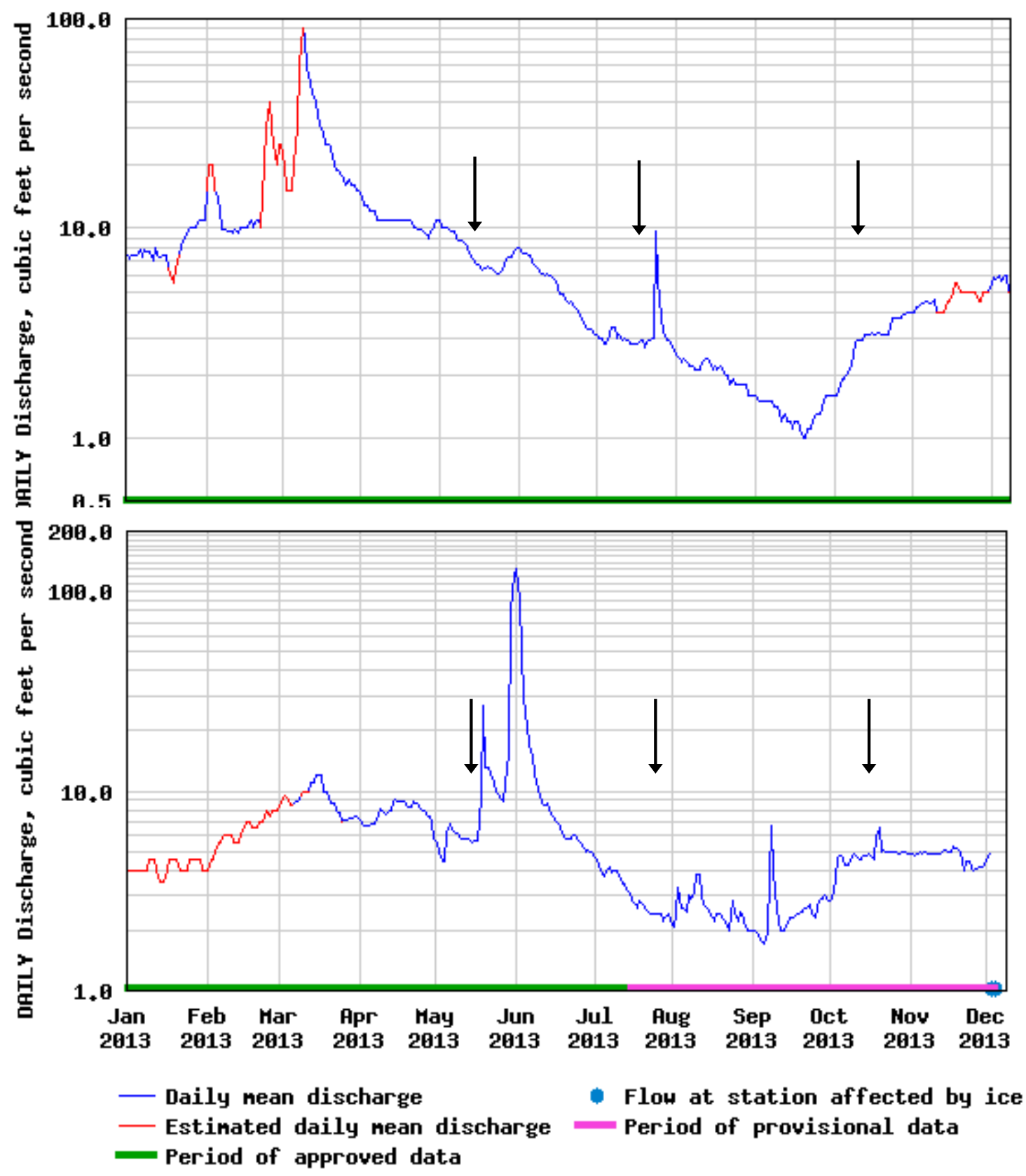

\section{Habitat Assessments}

The stream assessment reach was divided into 10 equally spaced transects according to BLM and EMAP protocols (BLM 2008a; Lazorchak et al. 1998). The downstream transect was marked (GPS, flagging and photo point) as the bottom of the reach and all ecological assessment protocols started from this point and continued upstream for $300 \mathrm{~m}$ (designated the assessment area or "AA") to the marked top of the reach. Parameters recorded at each transect were: wetted-width 
(WW), three channel depth measurements ( $1 / 4,1 / 2,3 / 4$ ww distance), $\%$ large woody debris, substrate and riparian shading. On-site habitat assessments were conducted using the rapid assessment protocol developed for the BLM by the National Aquatic Assessment Team (scores 0-24) (BLM 2008a). The process for determining Proper Functioning Condition followed Pritchard et al. (1993). Basic water parameters (temperature, TDS, $\mathrm{pH}$, conductivity) were recorded prior to biological sampling using a Horiba $\mathrm{H}-10$ water monitor, calibrated for the higher conductivity range. The Livestock Use Index ("Cowpie" CPI) was assessed by walking a randomly chosen $75 \mathrm{~m}$ transect on both sides of the stream channel in the riparian area within the assessment area and counting all the old and new cowpies (higher CPI equals high cow usage). The goal of these evaluations is to characterize local reach geomorphology, riparian and in-stream habitat, and characteristics that influence aquatic community integrity. Sites ranking higher using these protocols are determined to have higher quality local reach-scale habitat.

\section{Macroinvertebrate Communities}

Macroinvertebrate communities were sampled semi-quantitatively from each of the 10 transects within the 300m assessment reach using the EMAP Reach-Wide protocol (Lazorchak et al. 1998). Sampling started at the downstream transect (A) or \#10 in the BLM protocol, and proceeded upstream alternating sampling with the 500-micron D-frame net to the left, right or center of the

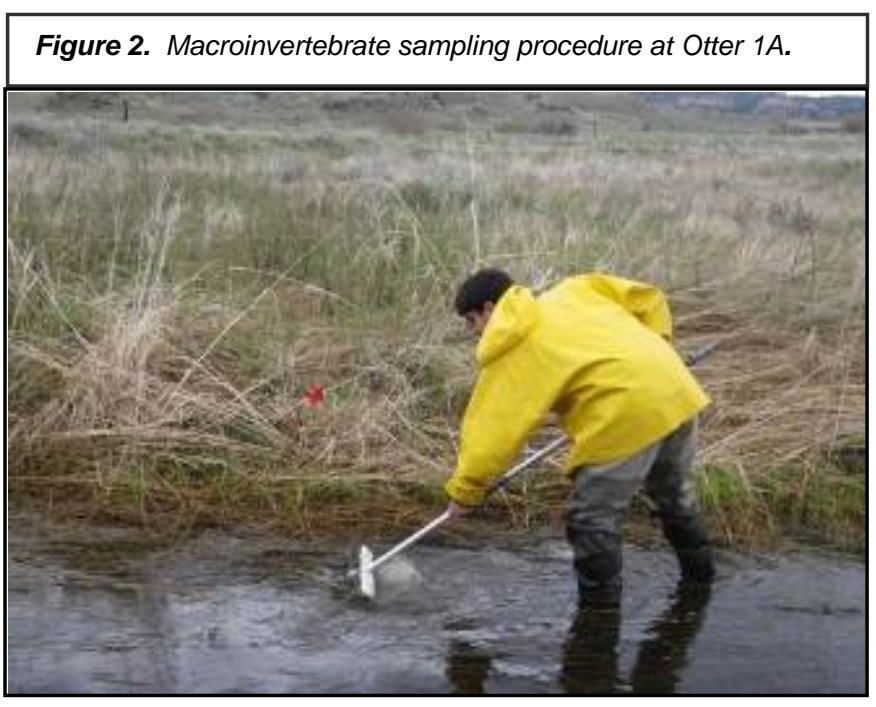

Table 2. Impairment determination thresholds from the MTDEO MMI and O/E (RIVPACS) models.

\begin{tabular}{|l|l|l|l|}
\hline Ecoregion & RVVACS & MMI & Impairment Determination \\
\hline \hline Mountain & $\geq 0.8$ or $\leq 1.2$ & $\geq 6.3$ & Not impaired \\
Low Valley & $<0.8$ or $>1.2$ & $<63$ & Impaired \\
& $\geq 0.8$ or $\leq 1.2$ & $\geq 48$ & Not impaired \\
& $<0.8$ or $>1.2$ & $<48$ & Impaired \\
Eastern Plains & $\geq 0.8$ or $\leq 1.2$ & $\geq 37$ & Not impaired \\
& $<0.8$ or $>1.2$ & $<37$ & Impaired \\
\hline
\end{tabular}
stream channel, so a systematic sampling of all habitats is achieved (Figure 2). The ten multi-habitat kicks/jabs were composited into a 20 liter bucket and processed according to BLM protocols (2008b). The organic portion on the sieve was transferred to one or two 1 liter Nalgene bottles, labeled and preserved in 95\% ethanol and brought to the MTNHP lab in Helena for processing (sorting, identification and data analysis) following protocols outlined by the BLM (2008b) and MTDEQ (2006). Macroinvertebrates were identified to the lowest taxonomic level (MTDEQ 2006), counted, imported into EDAS (Jessup 2006), and biological metrics were calculated from the data using the Montana Department of Environmental Quality's newest multimetric macroinvertebrate (MMI) protocols (Jessup et al. 2005, Feldman 2006). Metric results were scored using the MTDEQ bioassessment criteria and each sample categorized as 
nonimpaired or impaired according to threshold values (37 for Eastern Plains Streams, Table 2). The macroinvertebrate $\mathrm{MMI}$ score is based upon a series of metrics that measure attributes of benthic macroinvertebrate communities that are sensitive to condition changes in the stream (in the form of pollution or pollutants) including the Hilsenhoff Biotic Index (HBI) (MTDEQ 2006). The index score represents the condition of the macroinvertebrate community at the time the sample was collected within that past year. If the index score is below the impairment threshold, the individual metrics can be used to provide insight as to why the communities are different from the reference condition (Barbour et. al 1999, Jessup et. al. 2005). Spring and fall macroinvertebrate samples were collected outside the range of the MTDEQ recommended sampling time frame (June $1^{\text {st }}$-September $15^{\text {th }}$ ) (MTDEQ 2006), but this time frame was largely derived for mountain streams.

\section{Fish and Amphibian Surveys}

Fish sampling within the 300 meter stream assessment reach was conducted with 6 and 9 meter straight seines in 25-30 m increments, seining in a downstream direction toward a block seine (Figure 3, protocols in Bramblett et al. 2005). Fish captured in a blocked section were transferred to holding buckets until the reach was completed, unless the reach was broken up by riffles,

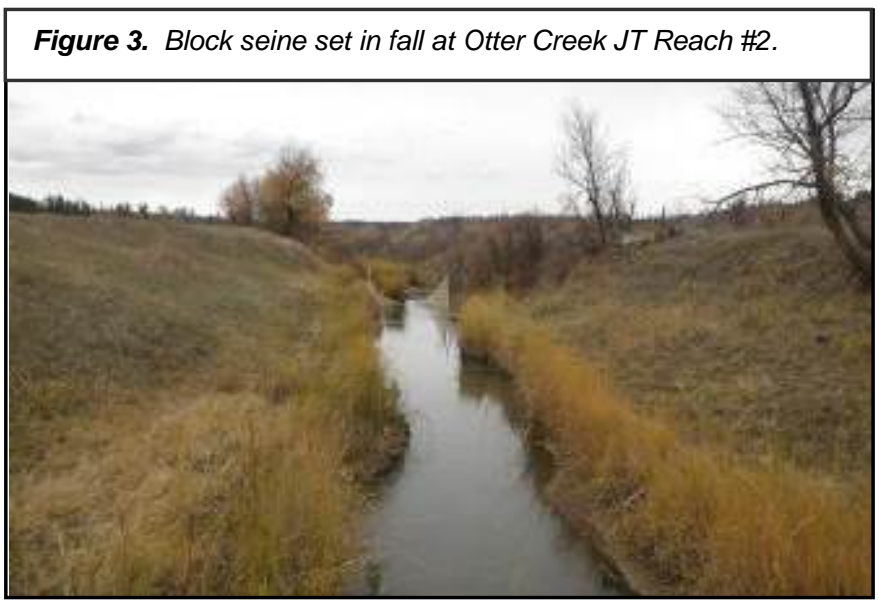
impassable or dry sections; in this case, fish were processed and released within the section of capture. Fish holding in the buckets were identified to species (Holton and Johnson 2003), enumerated, examined for external anomalies (e.g. deformities, eroded fins, lesions, and tumors; DELT), and then released. A fish anomaly score based on the number of individuals with anomalies divided by the total number of individuals collected (\%) was calculated for each survey. In general fish are more likely to develop anomalies including deformities, tumors, and parasites in areas with degraded water quality (USGS 2000). At least $10 \%$ of the individuals of a species were measured for total length in millimeters (TL $\mathrm{mm}$ ) to obtain size structure data. Young-of-the-year fish less than $20 \mathrm{~mm}(T L)$ were noted on the field sheet (not included in the totals) and released. Voucher specimens were only taken in the case of uncertain field identifications, and were preserved in $10 \%$ buffered formalin. These will be deposited with the Montana State University Collections. Adult amphibians or reptiles encountered while seining or walking the designated stream reach were counted and recorded even if they were not captured in the seine. All stream reaches were visually and aurally surveyed for amphibians or reptiles during all visits.

Analysis of the sampled fish communities used Integrated Biotic Indices (IBI) designed for wadable prairie streams (Bramblett et. al 2005) and derived Observed/Expected (O/E) Fish Models (Stagliano 2011) to detect impairment in the biological integrity of the sites. Proper classification is 
important when determining biological integrity (Hawkins and Norris 2000) and expected species richness. Stream reaches of Otter Creek have become dry in previous years (Stagliano, pers. observation. 2005-2008), thus placing certain stream sections within the D005 classification. We have characterized reference condition indicator assemblages for these ecosystem types previously (Stagliano 2005), which are used here to compare to our site-specific observed species. The expected number of native fish species for a D005 classified reference stream is 2.5-3.75, while the expected number of fish for a $\mathrm{CO05}$ stream is 5.5-8.5 depending on watershed area; dividing the observed number of native fish species at a site by the expected number derives a percentage compared to reference condition ( $>0.8$ or $80 \%=$ unimpaired) (Table 1 ). The IBI originally proposed by Karr (1981) involved the calculation of a series of 12 metrics evaluating different attributes of the fish community (i.e. species richness, tolerance to pollutants, trophic status) (Table 3). The 10 metrics used for the prairie streams were adjusted for watershed area to calculate an overall score between 0 and 100. Bramblett et al. (2005) did not propose threshold criteria for good, fair, and poor biological integrity for these scores. Therefore, we applied percentiles above the null criteria (no fish present score) at $>30 \%$ indicates good to excellent biological integrity, $10-30 \%$ fair/good biological integrity, 0-10\% indicated poor to fair biological integrity and scores below the null are indicative of poor biological integrity or severely impaired (Appendix A).

Table 3. Fish metrics and classification of fishes captured during the Otter Creek Study (2013).

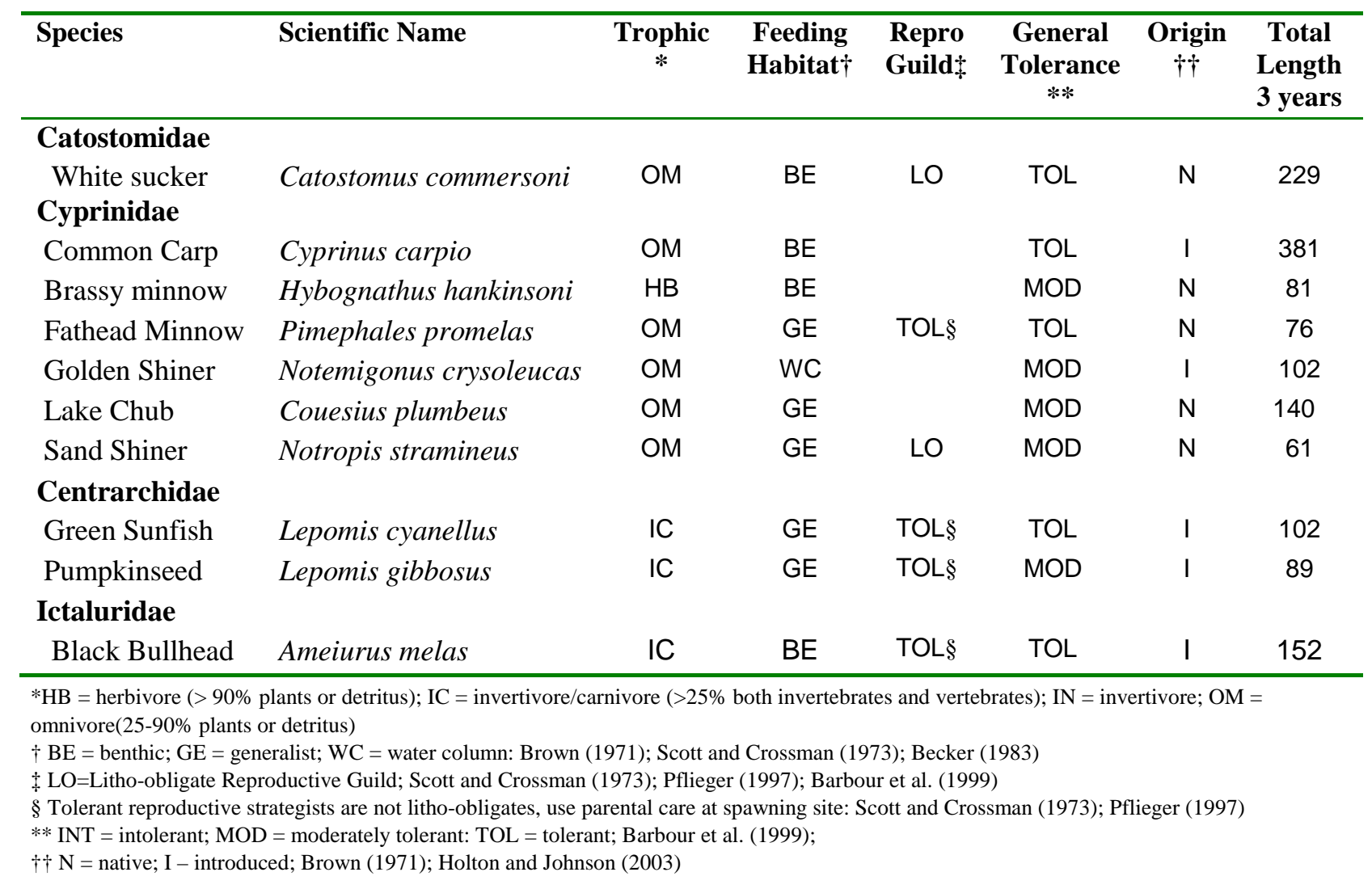




\section{Results}

We classified seven stream reaches in the study area: four Otter Creek mainstem sites are Perennial Prairie Streams (COO5), and three tributaries are classified as Great Plains Intermittent Prairie Streams (D005-Home Creek, E005-Tenmile Creek and Threemile Creek) (Table 1). The Intermittent Prairie Stream (E005) in Montana is naturally fishless $80 \%$ of the time; therefore, absence of fish, in itself, should not be viewed as a biological impairment (e.g. Threemile and Tenmile Creek). Amphibian populations, especially the northern leopard frog were highest at Home Creek (Otter_1A) (Table 6), which had a mix of permanent pools and fishless sections.

Habitat Evaluations. Of the seven sampling reaches evaluated within the study area, we found three in Proper Functioning Condition (PFC) with a stable trend and four ranked Functional at Risk (FAR) (Appendix C). Reasons that sites ranked FAR were due to structural habitat alteration by cattle with associated high livestock use indices (CPI values) (Home Creek $\left\{0 t t e r \_1 A\right\}$, Threemile Creek \{Otter_3m\} and Otter \#16-fall) (Figure 4) or anthropogenic stream manipulation (Otter Creek JT and Otter Creek \#16). Highest site integrity scores using both the BLM Habitat and PFC Assessment methods were recorded at the Otter Creek \#22 and JT, Denson and Trusler reaches

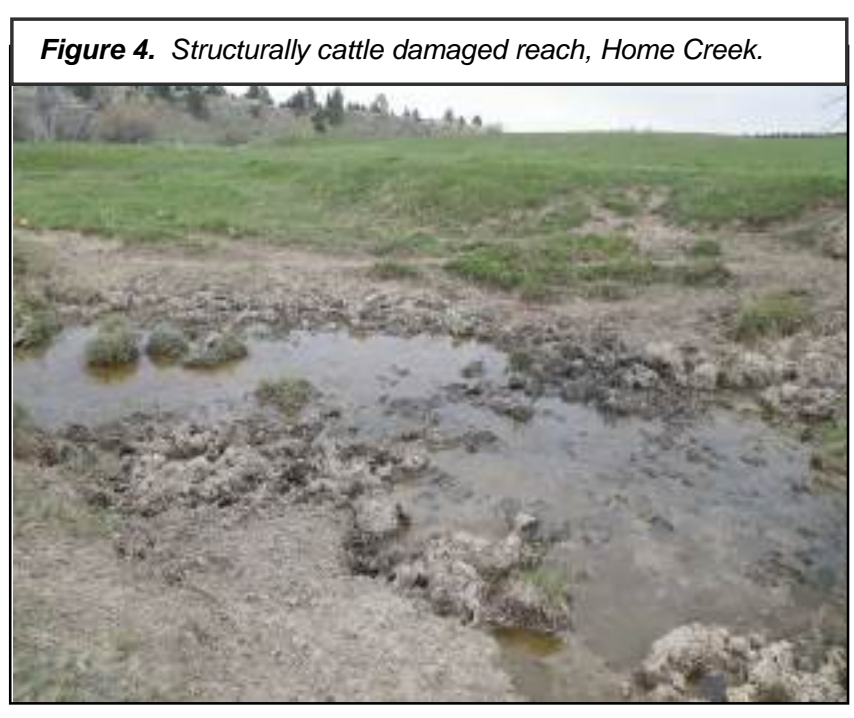

(Table 7). Point conductivity measurements recorded at all Otter Creek mainstem sites and tributaries across all seasons were above the threshold for impairment levels $(>500 \mu s$, DEQ 2006b, Appendix C), and Home Creek site had visible signs of natural gas seepage from the sediments. Percentage of silt in the benthic substrates has not significantly changed for any monitored reach during the three years of the study (Appendix C).

Macroinvertebrate Communities: Overall, 78 unique macroinvertebrate taxa were reported from the 13 macroinvertebrate assessment samples (Appendix B). One MT species of concern (SOC), the mayfly, Caenis youngi was collected at sites Otter Creek \#16 and \#22 (Appendix B). Stoneflies (P) 
were not present at any sites, so the EPT taxa reported per site usually consisted of two species of tolerant mayflies (E), and one or two species of caddisfly $(T)$; the highest EPT richness at any site was six species at the Otter_16 summer (Table 4, Appendix B). Average macroinvertebrate taxa richness per site was 29.1 and the highest taxa richness was 37 taxa reported at the Otter JT site during the fall survey (Table 4). There were no significant differences in total taxa richness, EPT taxa, or the Hilsenhoff Biotic Index (HBI) between mainstem treatments (ANOVA, $p>0.05$ ). Using the MTDEQ multimetric index (MMI), four of the five sites (11 of 13 samples) were ranked nonimpaired (good to excellent biological integrity), while two samples, one from Tenmile (Otter_23) and Home Creek (Otter_1A) were ranked impaired (Table 4, Figure 5).

Table 4. Macroinvertebrate sample characteristics and selected metrics used in the MTDEQ MMI (see Methods). Underlined MMI values are considered impaired. Ind.= Individuals

\begin{tabular}{|l|c|cccccccc|}
\hline Site ID & $\begin{array}{c}\text { Collection } \\
\text { Date }\end{array}$ & $\begin{array}{c}\text { \# of } \\
\text { Ind. } \\
\text { ID'ed }\end{array}$ & $\begin{array}{c}\text { Total } \\
\text { Per } \\
\text { Sample }\end{array}$ & $\begin{array}{c}\text { Total } \\
\text { Taxa }\end{array}$ & $\begin{array}{c}\text { Plains } \\
\text { MMI } \\
\text { Index }\end{array}$ & $\begin{array}{c}\text { EPT } \\
\text { Taxa }\end{array}$ & \% EPT & HBI & $\begin{array}{c}\text { \% Non } \\
\text { Insect }\end{array}$ \\
\hline Otter_23t2f & $10 / 14 / 2013$ & 484 & 484 & 12 & $\underline{32.6}$ & 0 & 0.0 & 7.0 & 6.8 \\
OTTER_22t2 & $5 / 17 / 2013$ & 516 & 2064 & 24 & 58.5 & 2 & 3.9 & 7.2 & 40.3 \\
OTTER_22t2s & $7 / 16 / 2013$ & 899 & 7,192 & 35 & 51.9 & 4 & 33.6 & 7.9 & 40.8 \\
OTTER_22t2f & $10 / 14 / 2013$ & 506 & 2,024 & 35 & 54.7 & 4 & 9.6 & 7.8 & 56.2 \\
OTTER_16t2 & $5 / 16 / 2013$ & 612 & 1224 & 27 & 61.2 & 5 & 12.4 & 7.2 & 32.7 \\
OTTER_16t2s & $7 / 16 / 2013$ & 534 & 1,068 & 32 & 53.7 & 6 & 27.3 & 7.3 & 14.2 \\
OTTER_16t2f & $10 / 14 / 2013$ & 528 & 1,056 & 32 & 53.4 & 5 & 22.7 & 7.1 & 22.9 \\
OTTER_JTt2 & $5 / 17 / 2013$ & 750 & 1,500 & 30 & 47.5 & 5 & 4.3 & 6.9 & 25.1 \\
OTTER_JTt2s & $7 / 17 / 2013$ & 503 & 2012 & 35 & 55.1 & 4 & 6.2 & 7.7 & 10.7 \\
OTTER_JTt2f & $10 / 15 / 2013$ & 503 & 2012 & 37 & 46.7 & 5 & 11.5 & 7.3 & 11.3 \\
OTTER_1At2 & $5 / 16 / 2013$ & 542 & 3,252 & 26 & 38.4 & 0 & 0.0 & 7.7 & 66.1 \\
OTTER_1At2s & $7 / 16 / 2013$ & 560 & 4478 & 25 & $\underline{29.6}$ & 1 & 0.01 & 7.7 & 55.7 \\
OTTER_1At2f & $10 / 15 / 2013$ & 538 & 2150 & 28 & 43.7 & 1 & 0.01 & 7.6 & 38.9 \\
\hline
\end{tabular}

No site had consistently high MMl scores across all seasons, though spring visits trended toward higher scores in 2013 (Figure 5). Stream sites that maintained flowing, connected water scored higher with the MMI than sites with interrupted pools. Otter Creek mainstem MMI scores were significantly higher than those in the tributaries (F-Test, $p<0.01$ ) (Figure 5). Macroinvertebrate MMI's did not significantly differ between Otter Creek mainstem site classes (Control, Impact or 
Downstream) or years (F-test, $\mathrm{p}>0.05$ ) (Figures 6 and 7); this is despite the fish communities reflecting an overall decrease in biotic integrity as you proceed downstream (Figure 11).

Figure 5. DEQ MMI scores across sites and seasons. Line is the MMI impairment threshold at 37.

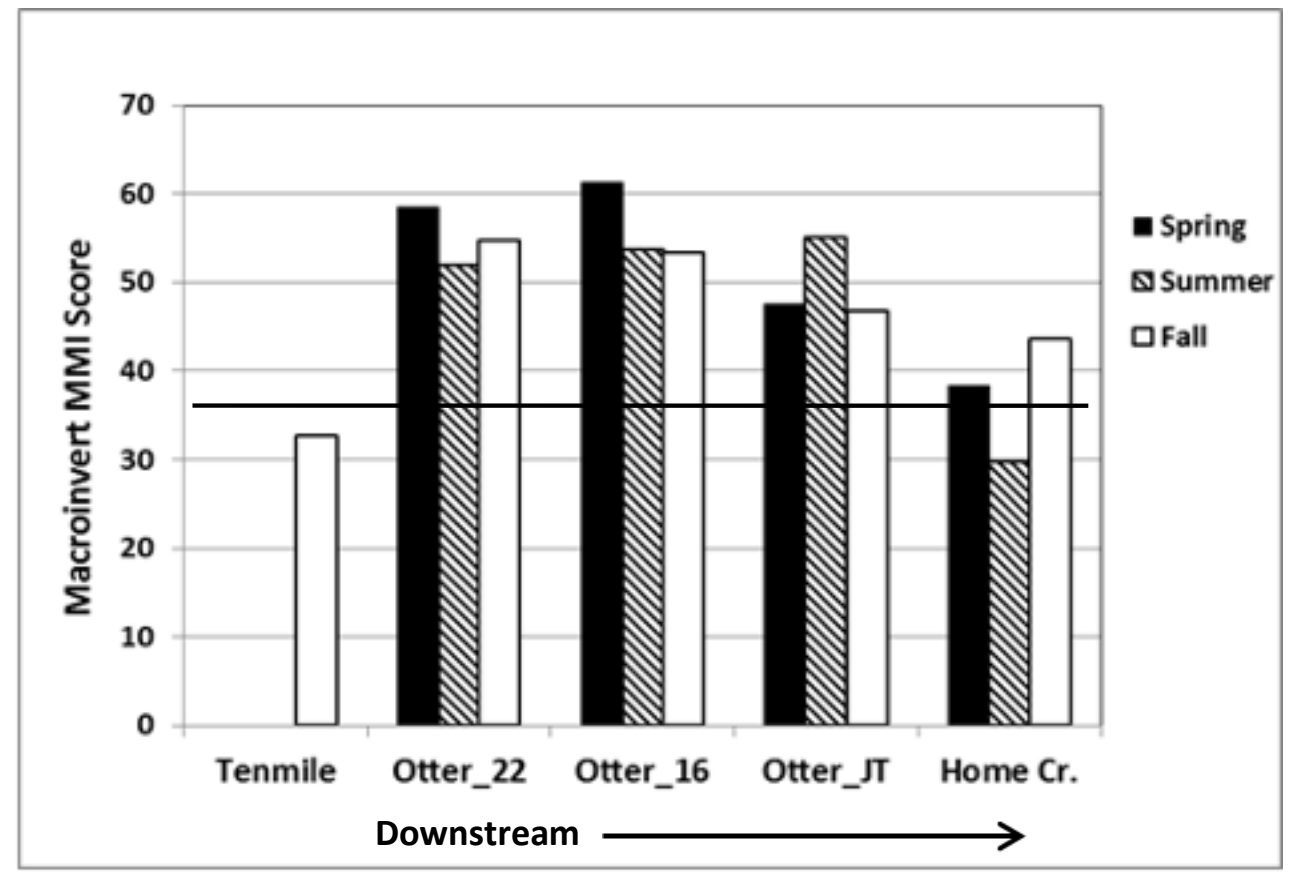

Figure 6. Average $\mathrm{MMI}$ scores by site type. (a) = no significant differences between treatments.

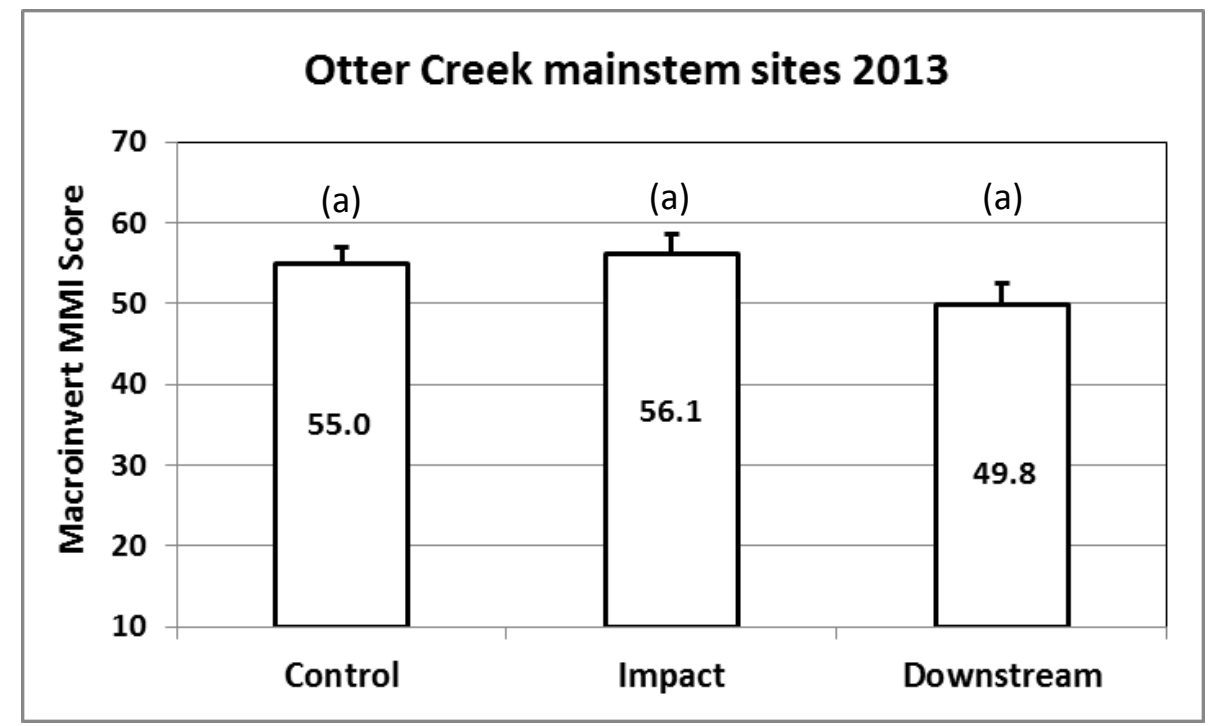

Over the three years of monitoring, macroinvertebrate integrity scores are stable at the control site, trending significantly upward at the Impact site (between 2011 and 2013, p=0.02) and 
downward, but not significantly at the downstream site (between 2011 and 2013, p=0.17) (Figure 7).

Figure 7. Average macroinvertebrate $M M I$ scores by treatment and year. Error bars are standard error (SE). (a) = no significant differences between treatments.

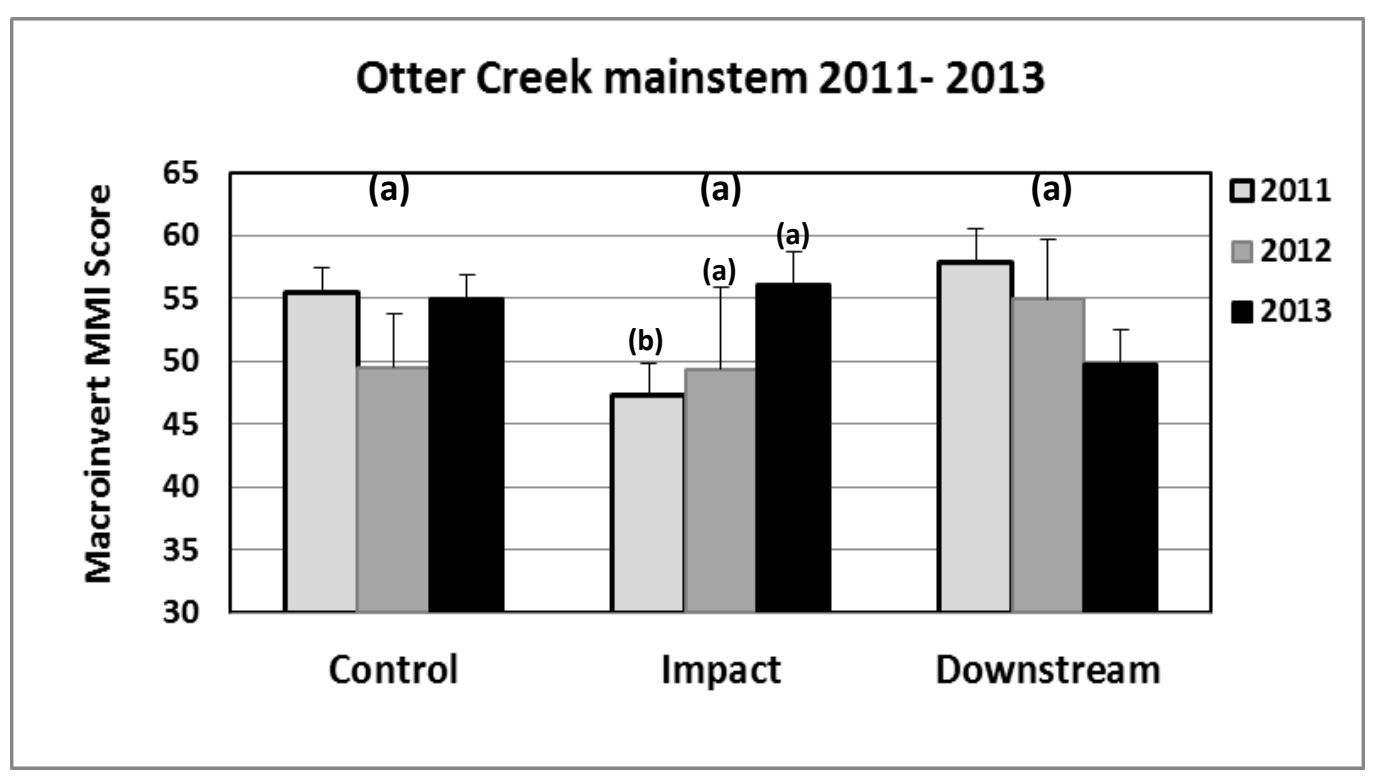

Fish Communities. In total, we performed 15 fish surveys during 2013; 12 at the four mainstem Otter Creek reaches and three surveys in one tributary stream during spring, summer and fall. Overall, ten fish species (five native/five introduced) were identified from 16,215 individuals collected during 15 surveys (Table 5). No additional species were added in 2013 to those we reported in 2012, and in fact, that new introduced species, the golden shiner which was widespread in 2012, was reported from only one site (Otter_16) during spring and summer surveys and then at no sites in the fall of 2013. Average total fish species per Otter Creek mainstem site across all seasons was 6.7 ( $\pm 0.5 \mathrm{SE}$ ), a slight decrease from $2012(7.0)$, while the tributary sites surveyed averaged 1.5 species (Table 5). Brassy minnows, a potential species of concern (PSOC), had the highest site occupancy rate of $100 \%$ (15 of 15 visits) followed by lake chubs, fathead minnows, and white suckers at $80 \%$ and $67 \%$ (12 and 10 out of 15 visits), respectively (Table 5 and 6). Lake chubs edged out fathead minnows in 2013 to account for the highest proportion of total individuals collected at $28 \%$ (Table 6). The most diverse fish site in the study area was Otter Creek \#16 with nine species, while sites with the highest \% of native species were Otter Creek JT (five spp.) and Home Creek (two native spp.) (Table 5). Otter Creek \#16 had the highest number of 
introduced species of any site ( $5 \mathrm{spp}$.) and the highest percentage of them in the fish community (93\%) (Figure 14). Using Montana's Prairie Fish IBI, 9 of the 15 fish visits ranked non-impaired (good biological integrity), five were slightly impaired and Otter \#16 fall was moderately impaired (poor integrity) (Table 5, Figure 8). As we observed in 2012, fish biotic integrity decreased going downstream in the Otter Creek mainstem (Figure 9) and seasonally with lower scores recorded during the fall (Figure 8). In 2013, Student T-tests of fish IBI scores of the Control Site were not significantly different than either the Impact $(p=0.089)$ or the Downstream site $(p=0.24)$, but the $O / E$ scores of the Control were significantly different than Impact sites $(p=0.018)$ and the Downstream site $(p=0.036)$ (Figures 9,10$)$. Despite no significance in 2013 , combining the three monitoring years for analysis showed fish IBI scores are significantly higher at the control site than the Impact $(p=0.006)$ or Downstream sites $(p=0.05)$ (Figure 11$)$. The $O / E$ scores tracked the $I B \mid$ in most cases, except at Otter Impact site \#2 summer, where the O/E showed non-impairment (0.91), but the IBI score (54) indicated impaired fish integrity. 
Table 5. Fish abundance, IBI's and O/E results for the 6 sites that have reported fish. ns = not seined during visit (dry). Underlined bolded values are fish communities that ranked biologically unimpaired.

\begin{tabular}{|c|c|c|c|c|c|c|c|c|c|c|c|c|c|c|c|c|c|c|c|}
\hline & \multicolumn{3}{|c|}{ OTTER_23 } & \multicolumn{3}{|c|}{ OTTER_22 } & \multicolumn{3}{|c|}{ OTTER_16 } & \multicolumn{3}{|c|}{ OTTER_2 } & \multicolumn{3}{|c|}{ OTTER_JT } & \multicolumn{3}{|c|}{ OTTER_1A } & \multirow[b]{2}{*}{ Total } \\
\hline & May & Jul & Oct & May & Jul & Oct & May & Jul & Oct & May & Jul & Oct & May & Jul & Oct & May & Jul & Oct & \\
\hline Black Bullhead* & ns & ns & ns & 18 & 351 & 0 & 149 & 595 & 18 & 18 & 7 & 0 & 0 & 0 & 2 & 0 & 0 & 0 & 1157 \\
\hline Brassy Minnow & ns & ns & ns & 513 & 670 & 88 & 109 & 434 & 6 & 11 & 53 & 60 & 13 & 15 & 2 & 39 & 44 & 32 & 2086 \\
\hline Common Carp* & ns & ns & ns & 0 & 0 & 0 & 62 & 248 & 189 & 0 & 11 & 8 & 10 & 23 & 14 & 0 & 0 & 0 & 564 \\
\hline Fathead Minnow & ns & ns & ns & 28 & 0 & 15 & 22 & 87 & 6 & 42 & 35 & 0 & 1318 & 1085 & 774 & 2 & 12 & 0 & 3425 \\
\hline Lake Chub & ns & ns & ns & 2825 & 945 & 79 & 74 & 298 & 0 & 210 & 14 & 26 & 43 & 75 & 4 & 0 & 0 & 8 & 4601 \\
\hline Green Sunfish* & ns & ns & ns & 3 & 35 & 29 & 6 & 25 & 0 & 25 & 4 & 8 & 0 & 0 & 0 & 0 & 0 & 0 & 133 \\
\hline Golden Shiner* & ns & ns & ns & 0 & 0 & 0 & 59 & 236 & 0 & 0 & 0 & 0 & 0 & 0 & 0 & 0 & 0 & 0 & 295 \\
\hline Pumpkinseed* & ns & ns & ns & 3 & 32 & 20 & 53 & 211 & 90 & 0 & 0 & 0 & 0 & 0 & 10 & 0 & 0 & 0 & 418 \\
\hline Sand Shiner & ns & ns & ns & 0 & 0 & 0 & 0 & 0 & 0 & 0 & 4 & 0 & 1060 & 900 & 234 & 0 & 0 & 0 & 2198 \\
\hline White Sucker & ns & ns & $\mathrm{ns}$ & 265 & 159 & 15 & 133 & 533 & 0 & 25 & 4 & 0 & 53 & 98 & 54 & 0 & 0 & 0 & 1339 \\
\hline Total \# species & 0 & 0 & 0 & 7 & 6 & 6 & 9 & 9 & 5 & 6 & 8 & 4 & 6 & 6 & 8 & 2 & 2 & 2 & 10 \\
\hline Native Species & 0 & 0 & 0 & 4 & 3 & 4 & 4 & 4 & 2 & 4 & 5 & 2 & 5 & 5 & 5 & 2 & 2 & 2 & 5 \\
\hline Total Individuals & 0 & 0 & 0 & 3653 & 2192 & 246 & 667 & 2666 & 309 & 329 & 130 & 101 & 2495 & 2196 & 1094 & 41 & 56 & 40 & 16,215 \\
\hline IBI & 56.1 & 56.1 & 56.1 & $\underline{71.1}$ & $\underline{60.5}$ & 57.8 & 55.0 & 51.9 & 44.7 & 64.1 & 54.5 & $\underline{60.9}$ & $\underline{62.8}$ & $\underline{63.3}$ & 56.1 & $\underline{69.0}$ & $\underline{64.3}$ & $\underline{72.8}$ & \\
\hline O/E & 0 & 0 & 0 & $\underline{1.07}$ & $\underline{0.80}$ & $\underline{1.07}$ & 0.73 & 0.73 & 0.36 & 0.73 & $\underline{0.91}$ & 0.36 & 0.67 & 0.67 & 0.67 & $\underline{0.82}$ & $\underline{0.82}$ & $\underline{0.82}$ & \\
\hline O/E \% & 0 & 0 & 0 & 106.7 & 80.0 & 106.7 & 72.7 & 72.7 & 36.4 & 72.7 & $\underline{90.9}$ & 36.4 & 66.7 & 66.7 & 66.7 & 81.6 & $\underline{81.6}$ & 81.6 & \\
\hline
\end{tabular}

* Denotes introduced species not native to Montana. 
In 2013, fish IBI scores decreased going downstream to the Impact sites and then rebounded further downstream, but IBI scores of the Control Site were not significantly different than either the Impact $(p=0.089)$ or the Downstream site $(p=0.24)$ using Student T-tests (Figure 9). The O/E scores of the Control were significantly different than Impact sites $(p=0.018)$ and the Downstream site $(p=0.036)$ (Figure 10). The $O / E$ scores agreed with the $|B|$ for indicating impairment in most cases (13 of 16), except at Otter Impact site \#2 Summer, where the O/E showed non-impairment (0.91), while the IBI score (54) indicates impaired fish integrity (Figure 12). Likewise with the fall survey at Otter $\# 22$ where the O/E indicates an intact fish community, but the IBI indicates slight impairment.

Figure 8. Fish IBI scores across sites and seasons. Line is the null IBI threshold (fish absent).

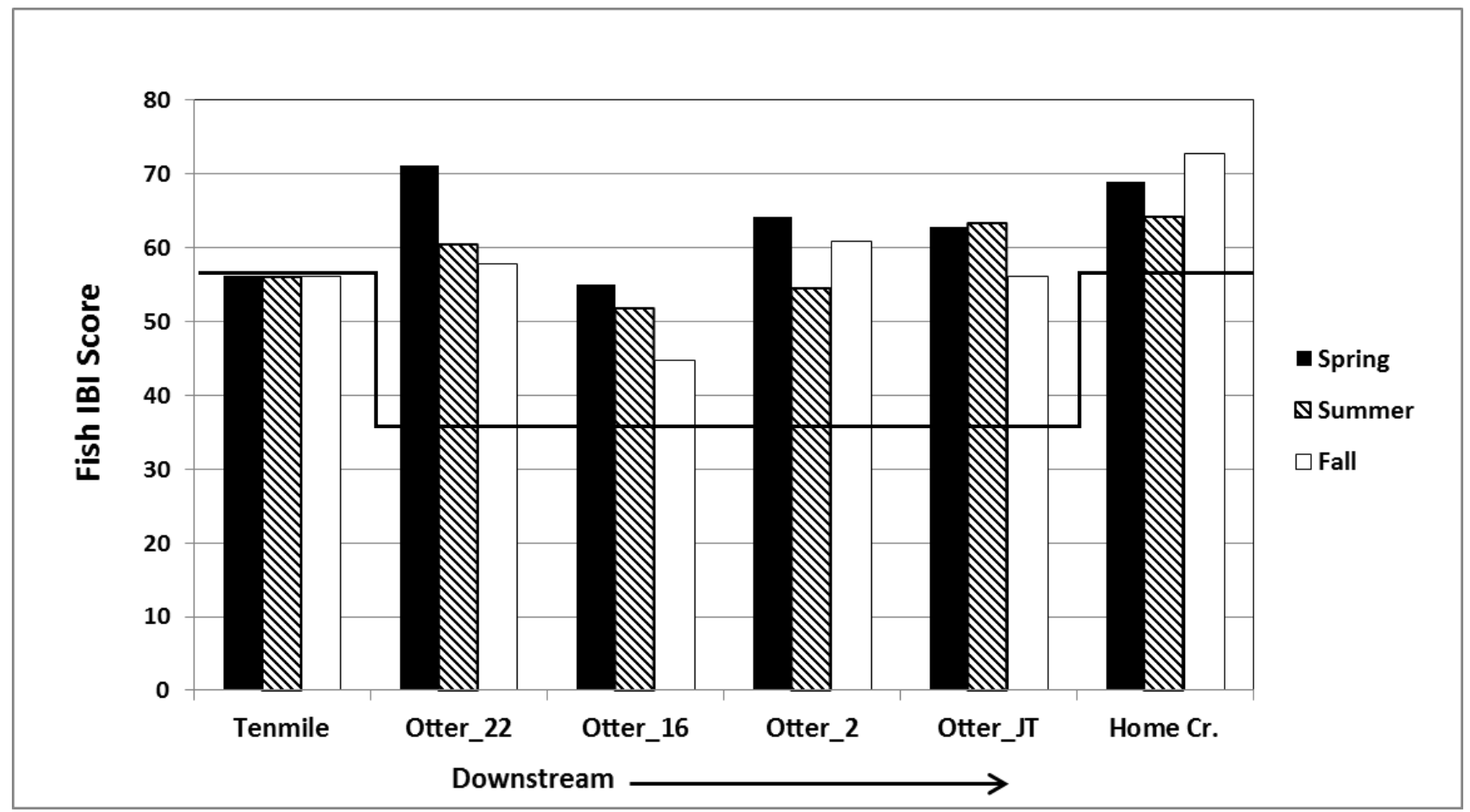

Further evaluations into the relationship of the $\mathrm{O} / \mathrm{E}$ to the $\mathrm{IBI}$ need to be addressed for stream sites with increasing numbers of non-native fish individuals, because the $\mathrm{O} / \mathrm{E}$ only scores native fish that are expected to occur at a frequency $>0 \%$ within a reference condition reach. 
Figure 9. Average fish $I B \mid$ scores by site type. (a) = no significant differences between treatments.

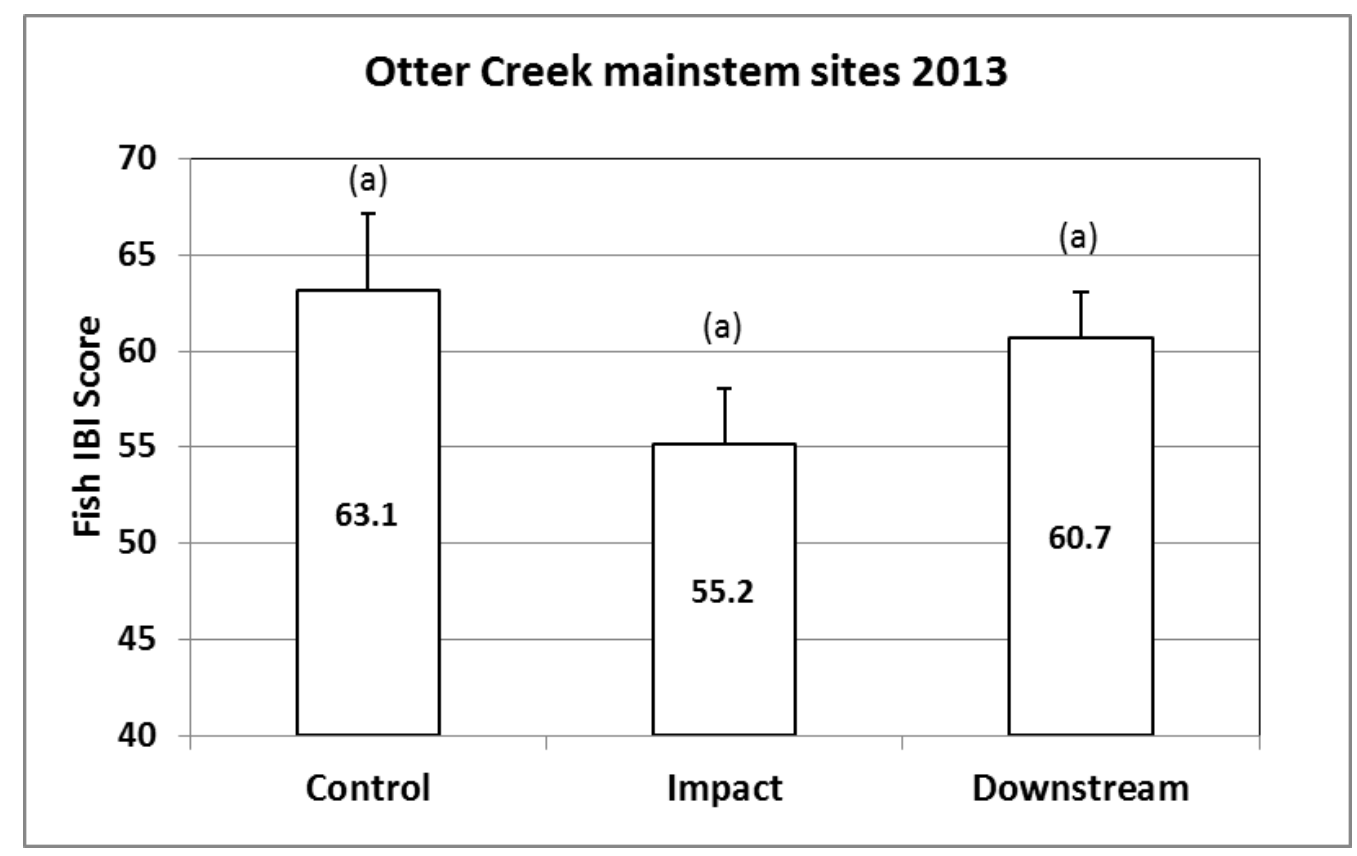

Figure 10. Average $O / E$ scores by site type. (a) = no significant differences between treatments.

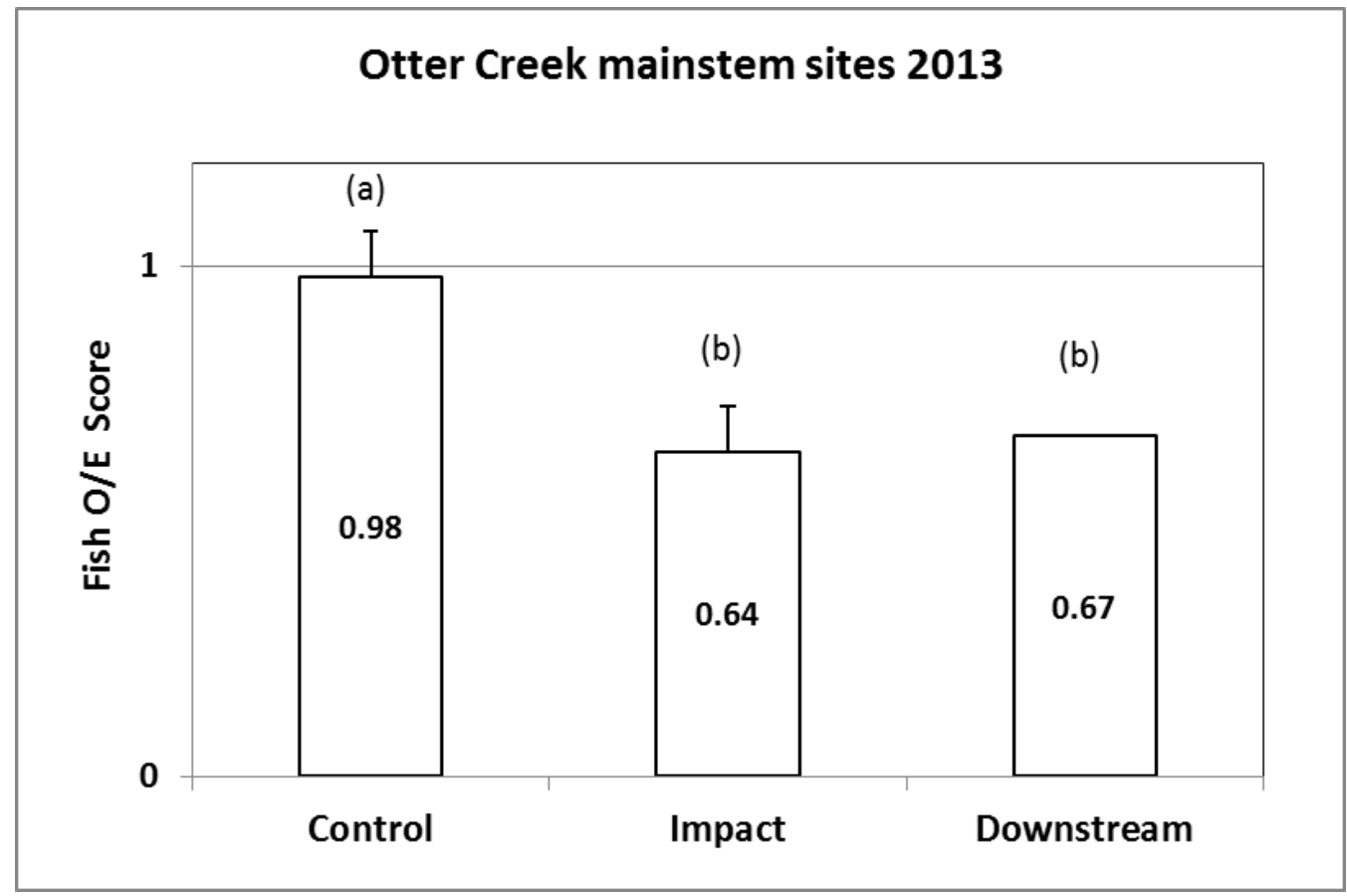


Figure 11. Average fish IBI scores by treatment and year. Error bars are standard error (SE). (a) = no significant differences between treatments.

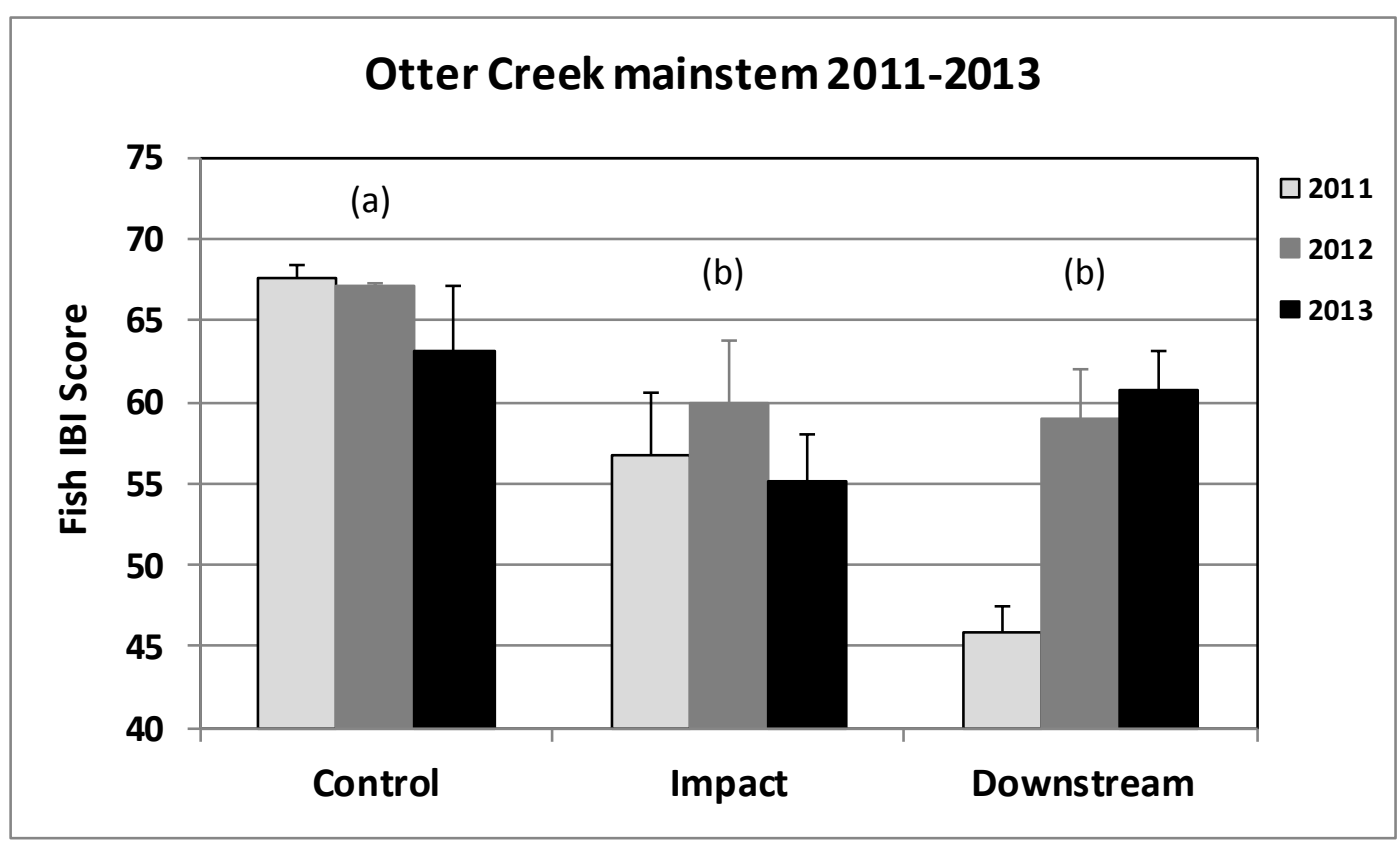

Figure 12. 2013 Fish IBI scores compared to O/E model (\%) scores across sites and seasons.

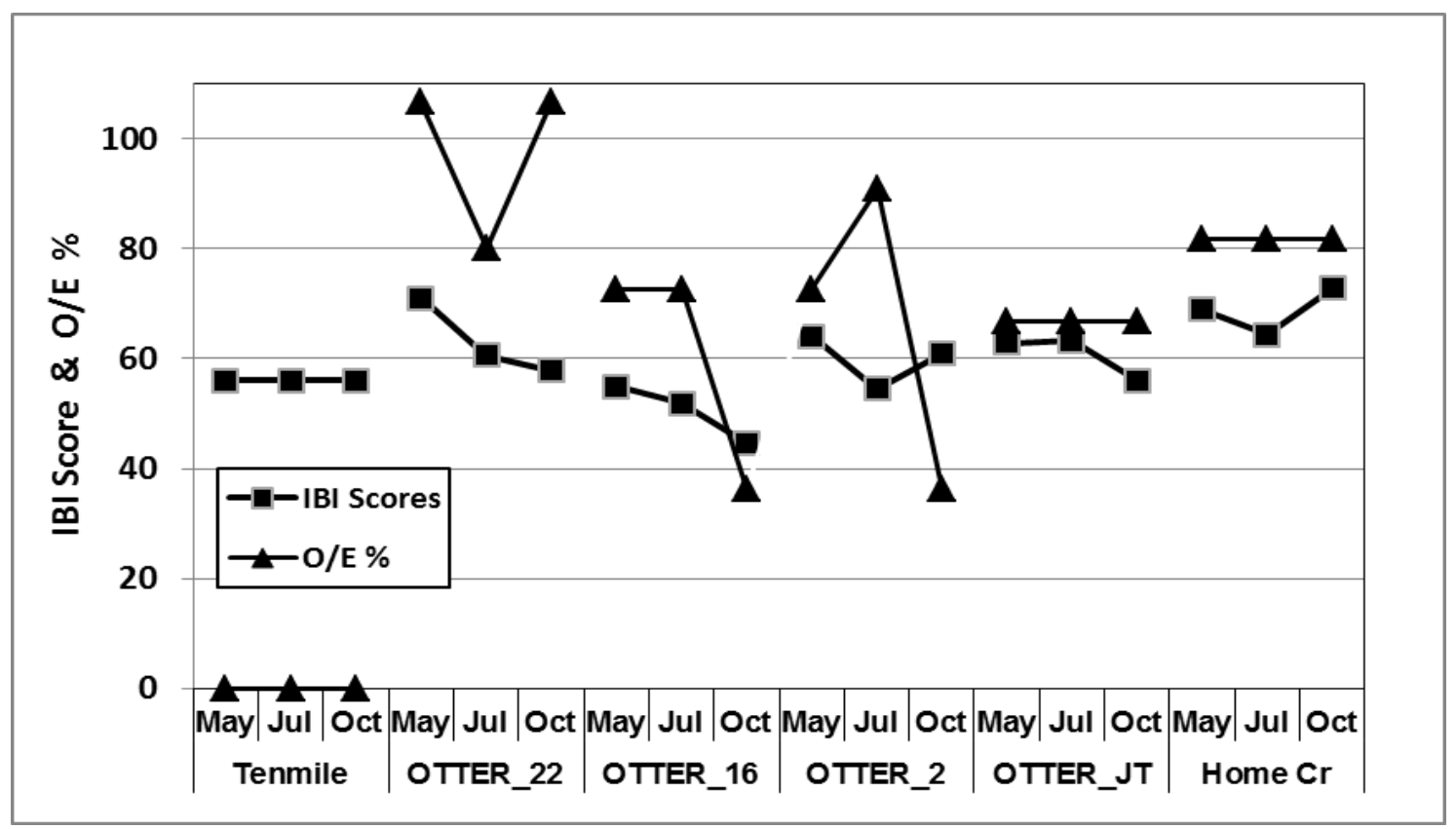

Fish IBI scores in 2013 showed similar seasonal patterns as in 2012, except with much higher IBI scores recorded during the Otter_JT spring survey and significantly lower IBI scores at Otter_2 during all visits (T-Test, $\mathrm{p}<0.05)$ (Figure 13). Otter Creek \#16 exhibited decreasing seasonal fish 
IBI scores during both years, while Otter Creek \#22 began to show this trend in 2013 (Figure 13). This lower integrity is significantly correlated with the decrease in the percentage of native fish individuals collected during visits (Figure 14).

Figure 13. Comparison of 2013 and 2012 Fish IBI scores across sites and seasons.

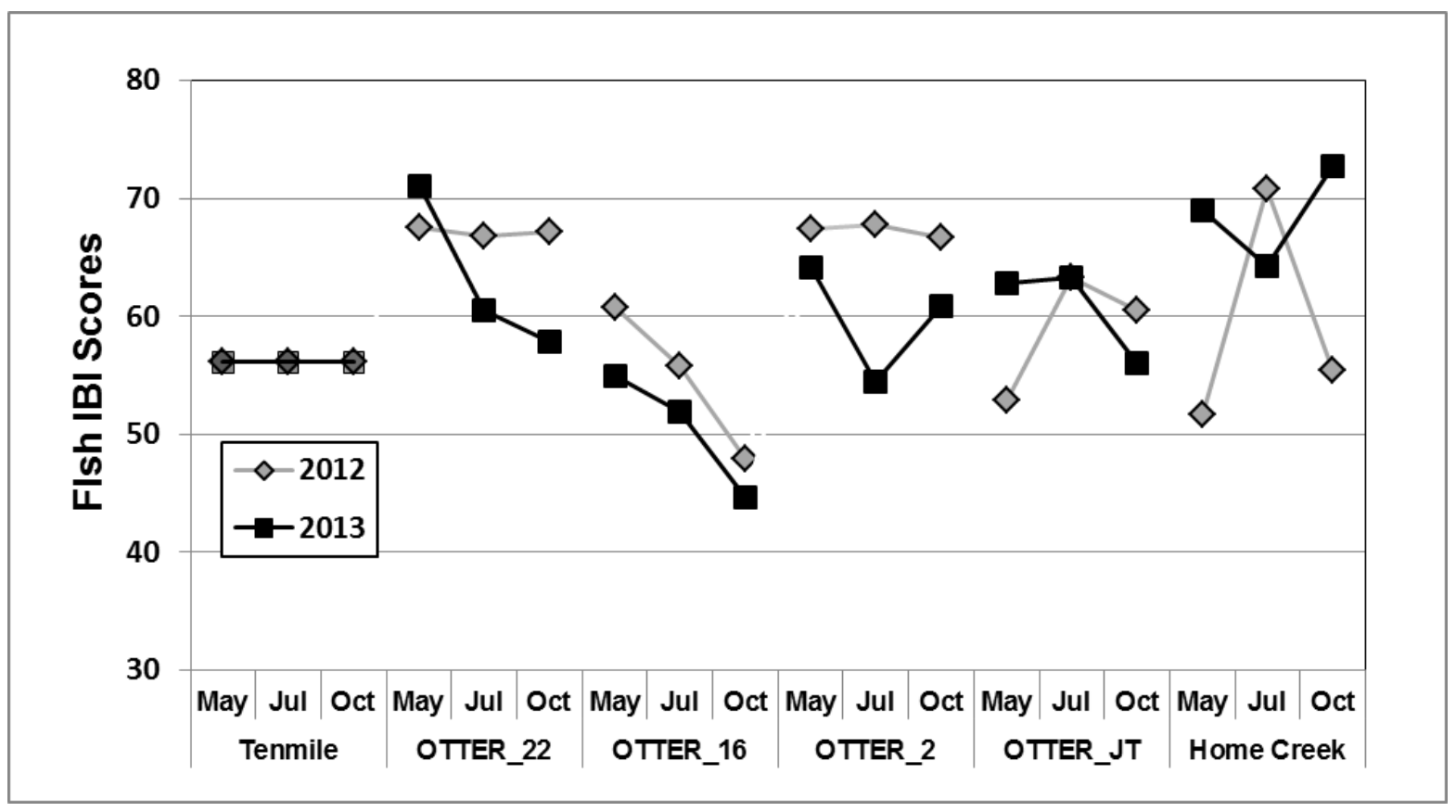

Otter Creek site 16 was heavily infested with introduced species during all 2013 seasonal visits representing $50 \%, 51 \%$ and $96 \%$ of the fish sampled, respectively. Percent native fish captured per survey continued to decline for 3 of the 4 mainstem Otter Creek Sites between 2012 and 2013 (Figure 14). All mainstem Otter Creek sites reported introduced species present during all surveys in 2013 (Table 5), but native fish species still dominated the percentage of total individuals of reaches except at Otter Creek \#16 (Figure 14). The highest percentage of native fish has been consistently reported at Otter JT for 2012 and 2013, while in the first year of the study it was Otter Creek \#22 (Stagliano 2011). It is likely that the "higher" water years since 2011 have favored the intrusion of non-native fish further upstream into Otter Creek mainstem reaches. Home Creek (Otter_1A) still maintains its fully native fish assemblage (Figure 14), likely due to an impassable barrier between Otter Creek and the monitoring reach. 
Figure 14. Comparison of 2013 and 2012 Native Fish Percentage (\%) across sites and seasons.

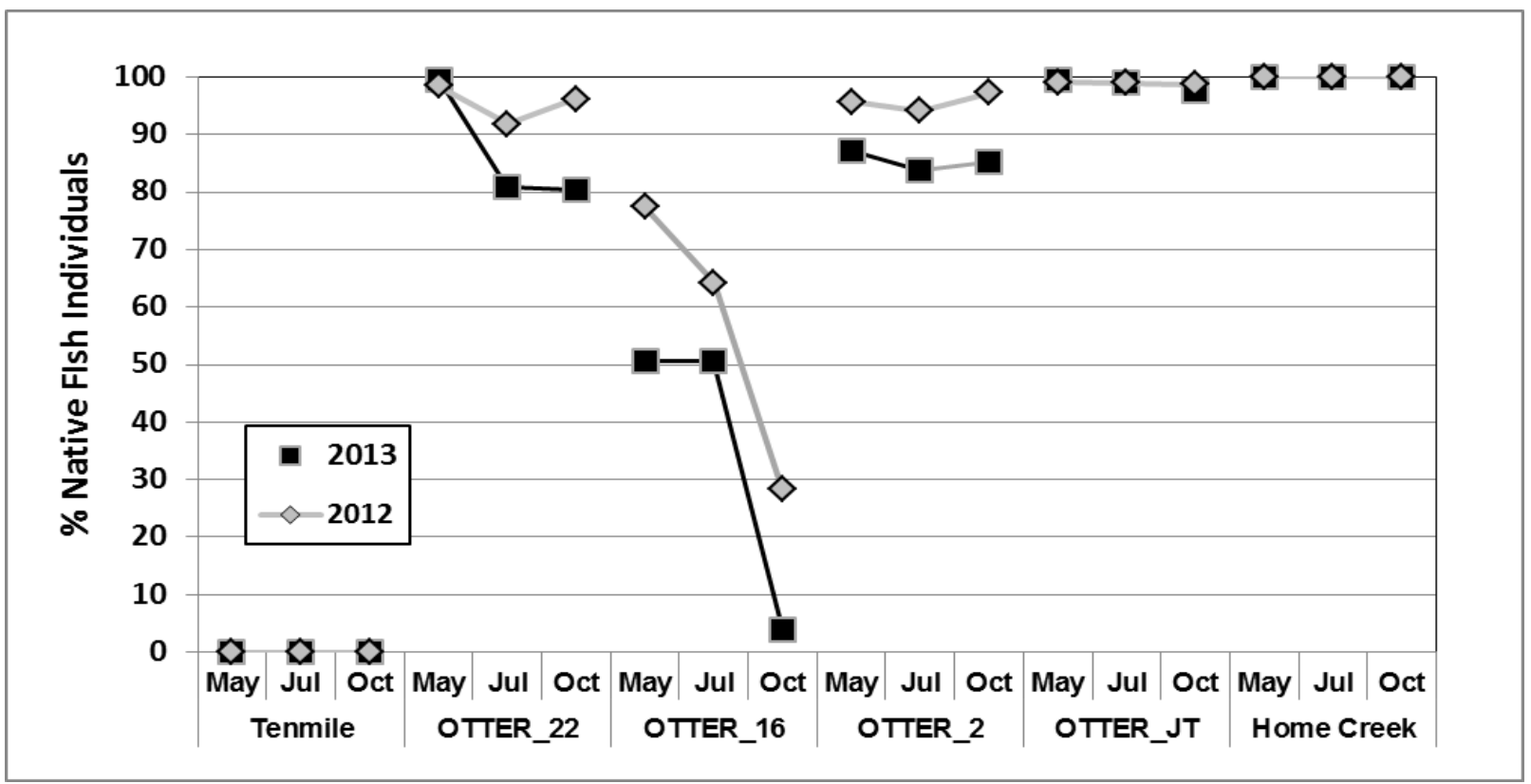

We report on the fish anomalies detected during the three sampling years (Figure 15). The overall highest percent of fish with anomalies occurred in spring at Otter_16 (31\%), while consistently high anomaly scores were reported at Otter_2 during all seasons in 2013, increasing each year since 2011, especially in the fall (Figure 15). We reported large numbers of fish with lesions and yellow grub in the fall of 2011 at the Otter_JT site (Stagliano 2012), but because the

Figure 15. Fish anomaly scores in 2013, 2012 and 2011 by sites and seasons.

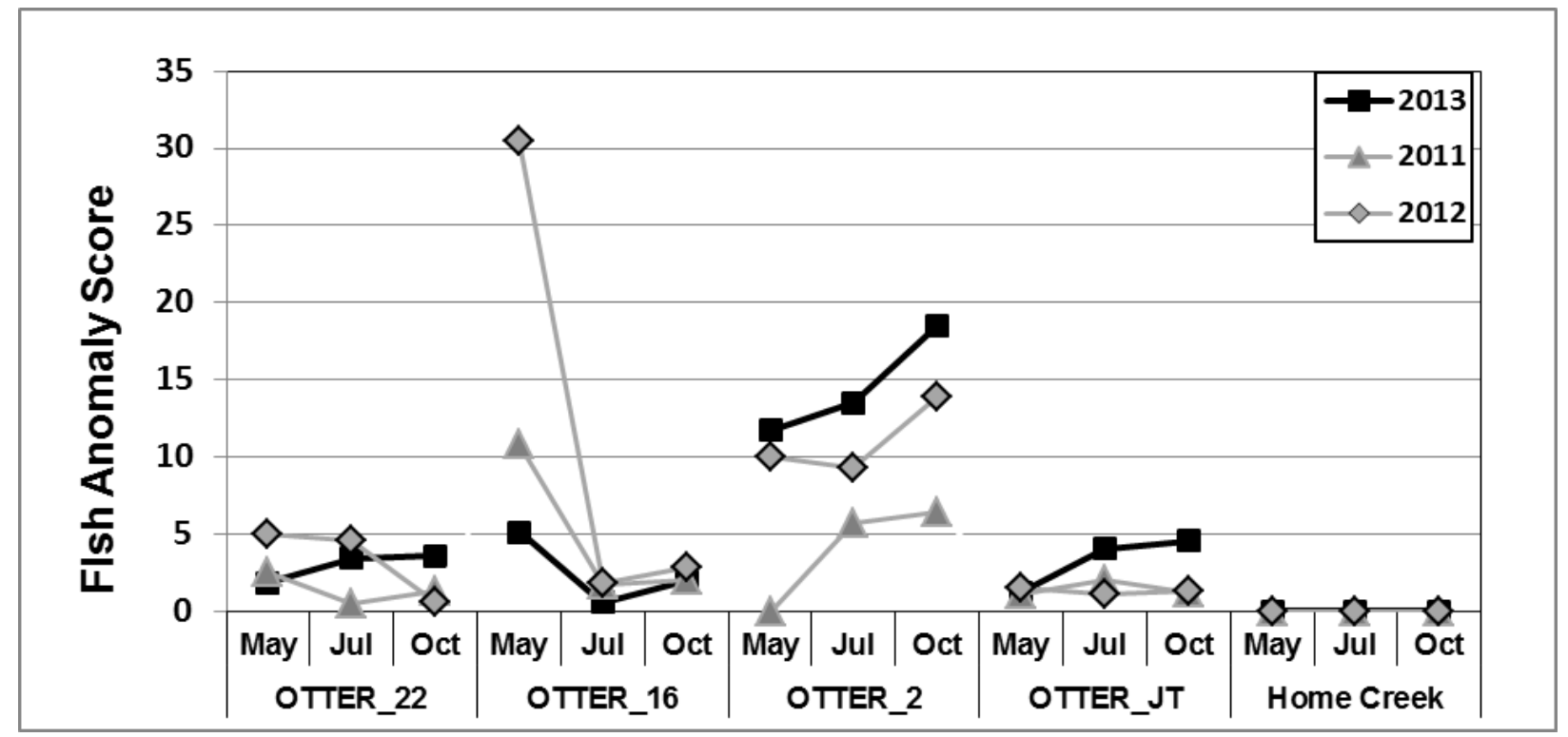


total fish catch was so abundant ( 20,000 fish per $300 \mathrm{~m})$, the actual $\%$ anomalies was low. Home Creek communities have very low fish densities and never reported an anomaly during any survey; neither did the Tenmile Creek spring 2011 fish survey. Student T-Test analysis showed that fish anomaly scores were significantly higher in the Impact Reaches (Otter \#16 and \#2) than either the Control ( $p=0.026)$ or Downstream reaches $(p=0.018)$ (Figure 16). Otter Creek site \#2 continues to report significantly higher numbers of fish with anomalies since 2011 (Figure 16).

Figure 16. Average fish anomaly scores by year and site. (a) = no significant differences between treatments.

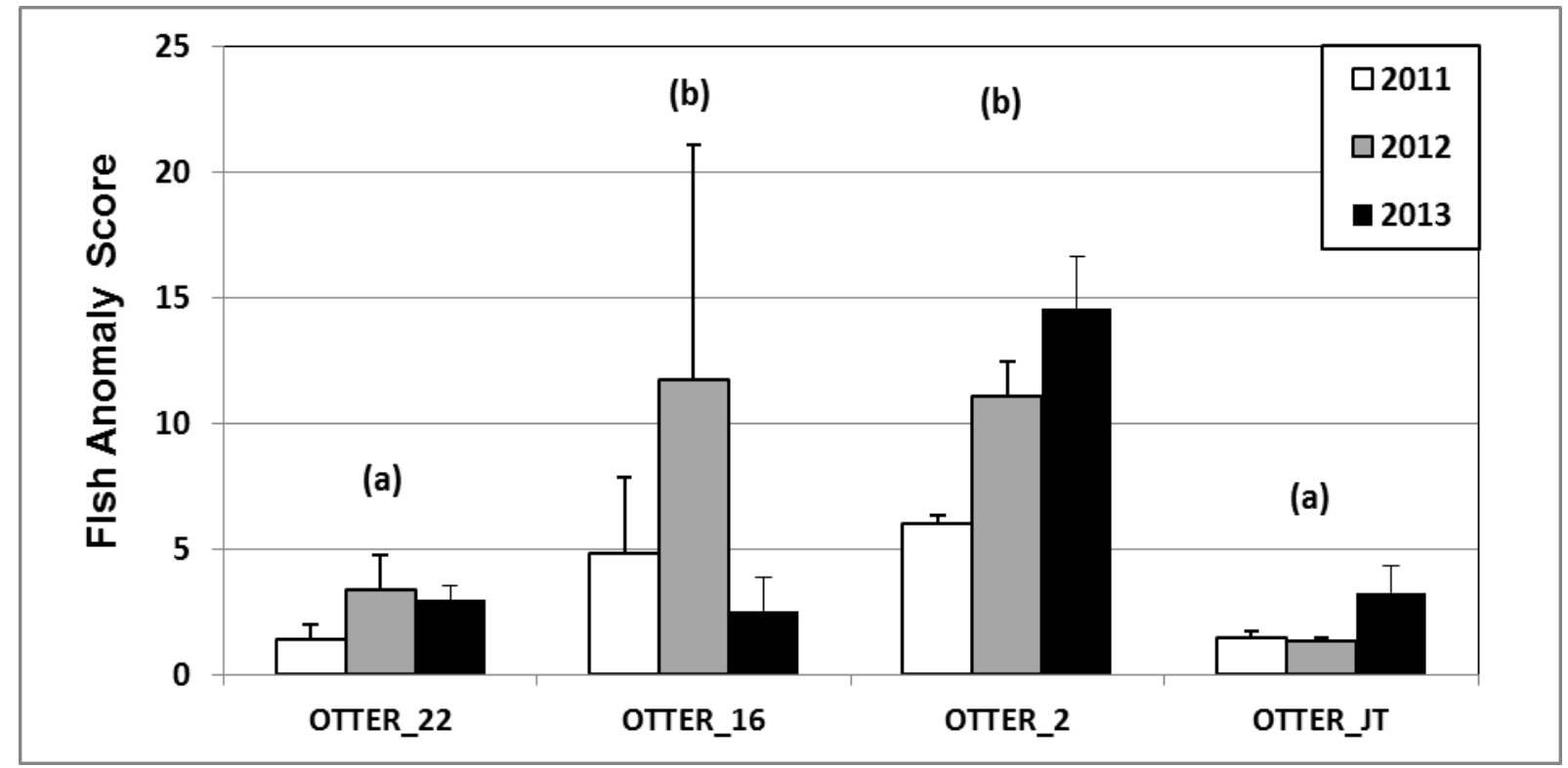

Amphibian and Reptile Observations. Overall, nine herpetofauna species were visually observed, collected in dipnets/seines or aurally recorded in conjunction with the 2013 surveys (Table 6). Otter Creek sites \#22 and \#16 were the most species rich in 2013 reporting five herpetofuana species cumulatively across all seasons. Of the four amphibian species detected, the Northern Leopard Frog (Lithobates pipiens) had the highest site occupancy, occurring at four of seven sites (seven detections), followed by the Woodhouse's Toad (Anaxyrus woodhousii) and Boreal Chorus Frog (Pseudacris maculata) recorded at three sites, five and four visit detections, respectively (Table 6). Boreal Chorus Frog adults were detected vocally calling during the spring visits at two sites (Home Creek and Otter_16) and as juveniles ( $n=15)$ at Tenmile Creek 
(Otter_23), despite the stream channel being dry during the spring and summer visits. Woodhouse's toad juveniles $(n=3)$ were also reported at Tenmile Creek during the summer visit. Tiger salamanders (Ambystoma tigrinum) continue to use Home Creek (Otter_1A) as a breeding area, as evidenced by larvae $(n=8)$ captured while seining for fish during the summer visits. We also recorded five reptile species (in order of site occurrence): Painted Turtle (Chrysemys picta), Snapping Turtle (Chelydra serpentina) (MTSOC), Western Rattlesnake (Crotalus viridis), Gopher snake (Pituophis catenifer) and Terrestrial Garter Snake (Thamnophis elegans) (Table 6, Figure 17).
Table 6. Vertebrates (Species Code) recorded during the 2013 Otter Creek Surveys. Frequency of Occurrence (FO) calculated from the \# of visits detected / \# of total visits. Herps ( $n=21)$ and Fish $(n=15)$. \% of Total Herp Individuals. ${ }^{*}=$ Introduced Species

\begin{tabular}{|l|c|c|c|}
\hline \multicolumn{1}{|c|}{ Herpetofauna } & $\begin{array}{c}\text { Visits } \\
\text { Detect }\end{array}$ & F of O & $\begin{array}{c}\% \text { of } \\
\text { total }\end{array}$ \\
\hline Northern Leopard Frog (RAPI) & 7 & 0.33 & 0.41 \\
\hline Woodhouse's Toad (BUWO) & 5 & 0.24 & 0.09 \\
\hline Boreal Chorus Frog (PSMA) & 4 & 0.19 & 0.28 \\
\hline Painted Turtle (CHPI) & 4 & 0.19 & 0.05 \\
\hline Snapping Turtle (CHSE) & 2 & 0.10 & 0.03 \\
\hline Tiger Salamander (AMTI) & 2 & 0.10 & 0.11 \\
\hline Western Rattlesnake (CRVI) & 2 & 0.10 & 0.03 \\
\hline Terrestrial Gartersnake (THEL) & 1 & 0.05 & 0.01 \\
\hline Gopher Snake (PICA) & 1 & 0.05 & 0.01 \\
\hline & & & \\
\hline Brassy Minnow (BRMI) & 15 & 1.00 & 0.13 \\
\hline Lake Chub (LACH) & 12 & 0.80 & 0.28 \\
\hline Fathead Minnow (FAMI) & 12 & 0.80 & 0.21 \\
\hline White Sucker (WHSU) & 10 & 0.67 & 0.08 \\
\hline Black Bullhead (BLBU)* & 8 & 0.53 & 0.07 \\
\hline Common Carp (CARP)* & 8 & 0.53 & 0.03 \\
\hline Green Sunfish (GRSU)* & 8 & 0.53 & 0.01 \\
\hline Pumpkinseed (PUMP)* & 7 & 0.47 & 0.03 \\
\hline Sand Shiner (SASH) & 4 & 0.27 & 0.14 \\
\hline Golden Shiner (GOSH)* & 2 & 0.13 & 0.02 \\
\hline
\end{tabular}

Figure 17. Snapping Turtle (adult) and Terrestrial Garter Snake (right) from Otter Creek \#22 and JT.
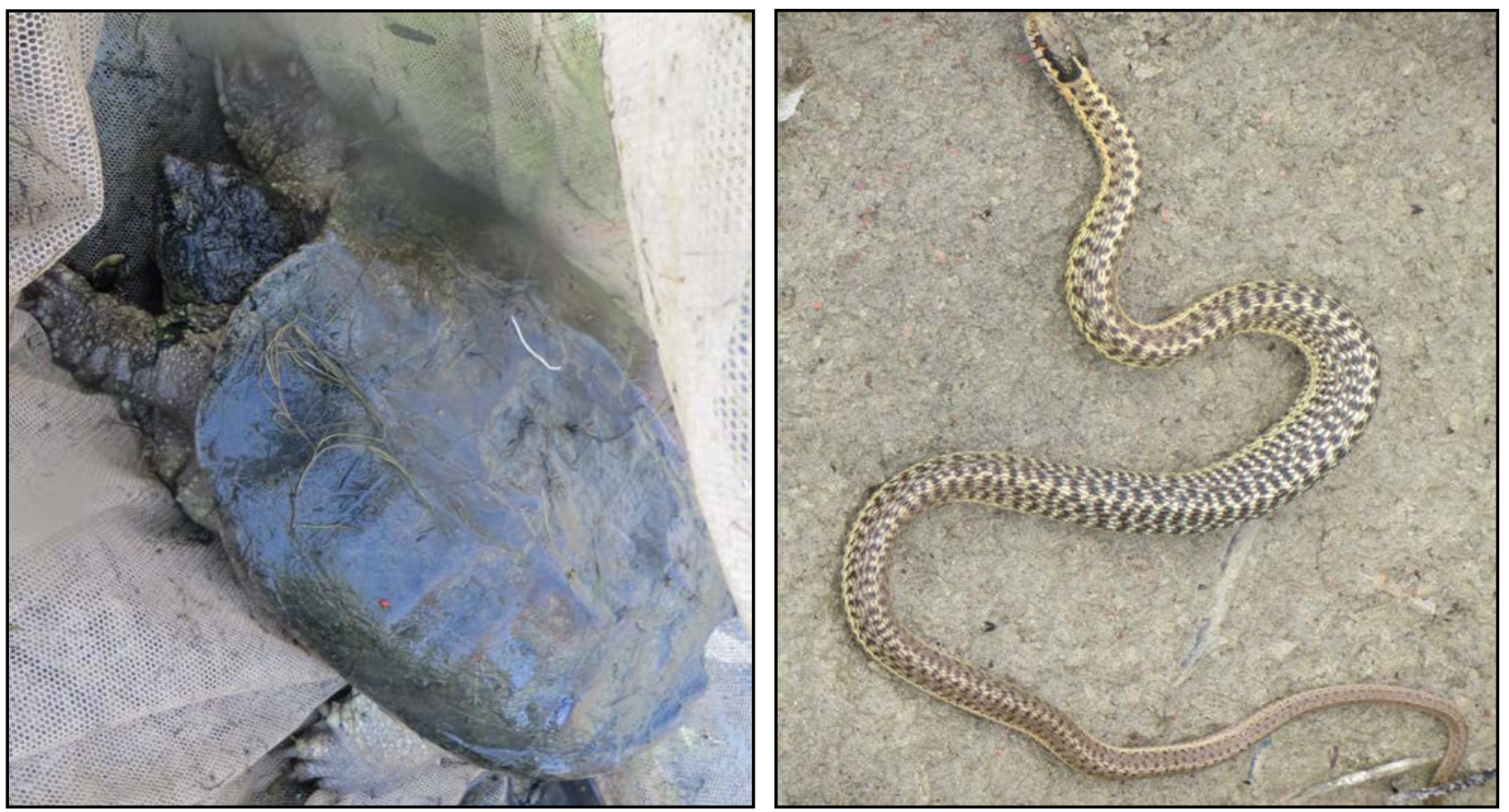


\section{Conclusions}

Otter Creek mainstem reaches within the area proposed for the mine site (i.e. Impact zone) continue to show higher impairment levels in biological integrity than the Control or Downstream reaches. Spatial and temporal patterns of aquatic community composition and biotic integrity were similar between the 2013 and 2012 surveys, with a notable increase in the percentage of non-native fish occurring across most sites, especially at the Impact sites in the fall. This pattern may be related to the unusual discharge pattern in 2013 with a high flow event in early summer during warmer water temperatures potentially increasing the colonization of large numbers of introduced fish upstream. This increase in non-native fish led to the subsequent decrease in community integrity seen in summer and fall surveys. While 2013 sampling data showed similarities in macroinvertebrate integrity patterns, there were some significant deviations in fish integrity results from 2012. Fish biological integrity of the upstream control reach of Otter Creek (Otter \#22) remains significantly higher and more stable than the lower Otter Creek reaches over the three years of monitoring, but even this site has suffered from the effects of increasing numbers of introduced species. Sites surveyed within the Impact Zone (Otter \#2 and \#16) exhibit some measure of impairment for all indicators of fish integrity (IBI's, O/E, \% Native and \% Fish Anomalies). Otter Creek \#16 continues to exhibit decreasing seasonal trends in the fish IBI during all years and reports increasingly higher numbers of introduced fish in the surveys. A potential reason for this accumulation of introduced fish at Otter \#16 may be related to the graveled road crossing or another putative barrier upstream of the reach acting as a barrier to fish movement during low water periods, but this is unconfirmed. The fish anomaly score may somehow be related to the increasing numbers of introduced fish at the Impact Sites because the \% of anomalies is also significantly higher at these sites. Oddly enough, fish anomalies largely affect native species with white suckers, fathead minnows and lake chubs showing the highest infection rates. This may indicate that native species are more sensitive to infections when stressed by high densities of introduced fish, especially potential predators, such as black bullhead.

Despite the large discharge pulse of approximately $100 \mathrm{cfs}$ in the early summer, stream flows this year were lower overall than in 2012, but still were above the 35 year average. The spring and summer 2013 visits to Tenmile Creek revealed a dry stream channel while in previous years small isolated pools were reported, but surprisingly Tenmile Creek still reported two species of juvenile 
amphibians (PSMA and BUWO). Spring visits had the highest detection rate for herpetofauna as reptiles were coming out of hibernation and amphibians were in breeding mode. This indicates that there are breeding pools adjacent to the survey reach, either in the stream or in off channel wetlands.

Outside of coal extraction, manageable threats to this watershed include grazing and livestock use around the riparian areas. Moderate use of the riparian zone by cattle in the basin can have strong local effects resulting in sedimentation, stream widening where cattle access the stream and loss of functional channel hydrology. Introductions of game fish (green sunfish, bullheads or pumpkinseeds) or forage fish (golden shiners) in stock ponds anywhere in the watershed can pose potential problems for native fish, as these introduced fish become permanent residents, outcompete or prey upon the native fish and contribute to overall community degradation. Diverse aquatic communities with high biological integrity are usually correlated with good riparian condition and habitat quality (Allen et al. 1997). Thus, effective riparian zone management (e.g. fencing, pasture rotation) while grazing cattle would contribute to intact vegetation buffers and less sediment in the aquatic environment (George et al. 2002). During all years of the study, macroinvertebrate communities assessed by the MTMMI ranked few sites as impaired, even those with an obviously impaired riparian condition and in-stream habitat degradation. The effectiveness of macroinvertebrate communities in assessing prairie stream impairment, especially for sediment, is still under debate in Montana. Thus, placing more emphasis on the fish communities or habitat assessment scores in fishless streams may be necessary in monitoring intermittent prairie streams.

Assessment results from the habitat, fish and macroinvertebrate surveys combined to rank the following sites from highest biological integrity to lowest within their aquatic ecological classification codes:

Northwestern Great Plains Perennial Prairie Stream (AES code C005)-1) Otter Creek \#22, 2) Otter Creek J Trusler, 3) Otter Creek \#2, 4) Otter Creek \#16

Northwestern Great Plains Intermittent Stream-(AES D005)-1) Home Creek (Otter_1A)

Great Plains Intermittent Fishless Stream (AES code E005)-1) Tenmile Creek, 2) Threemile Creek 


\section{Site Photos}

Otter Creek \#22 (control) during spring (left) and summer 2013 visits (right)

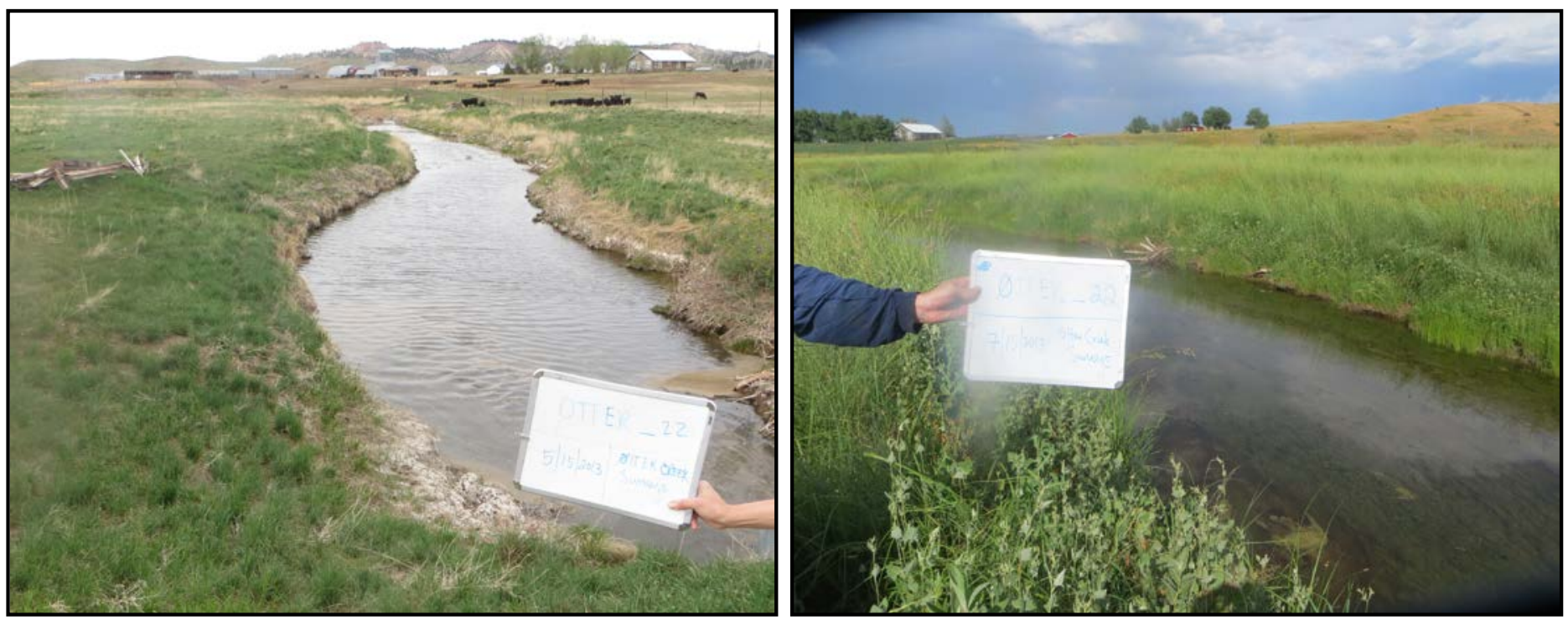

Otter Creek JT (downstream): summer (left) and fall (right) 2013 visits looking downstream
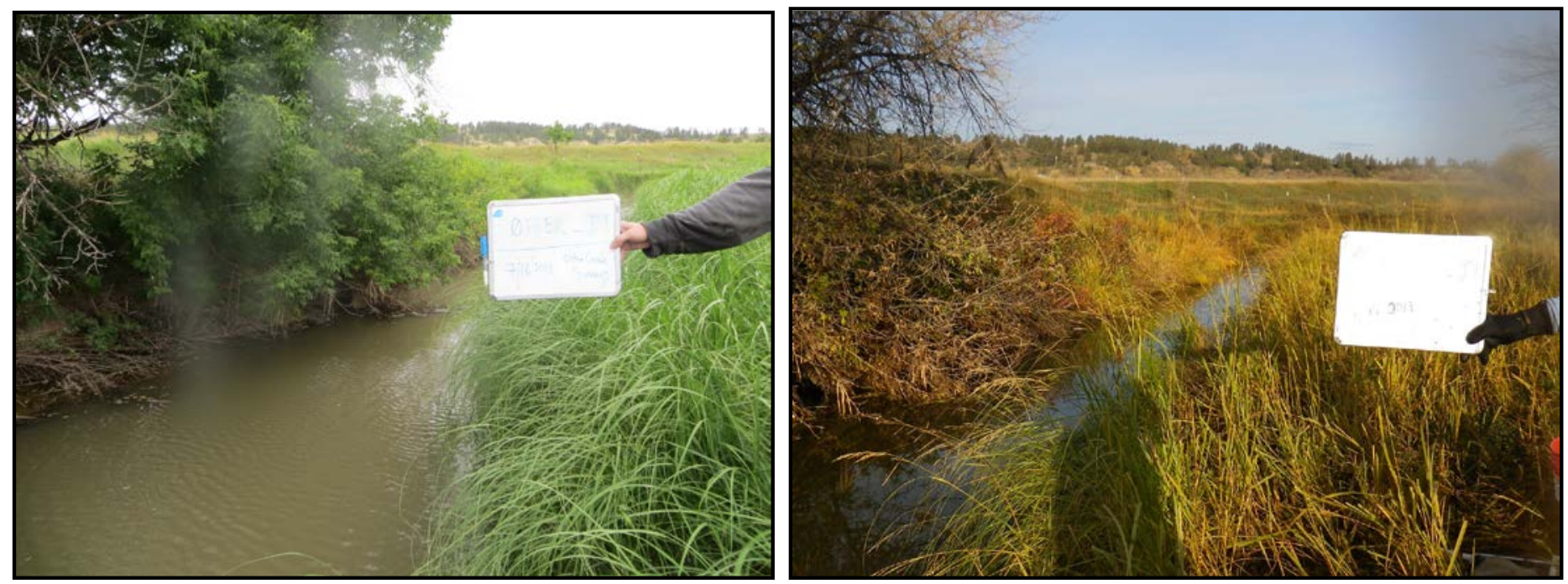

Otter Creek \#2 (impact): spring (left) and fall (right) visit 2013 looking downstream.
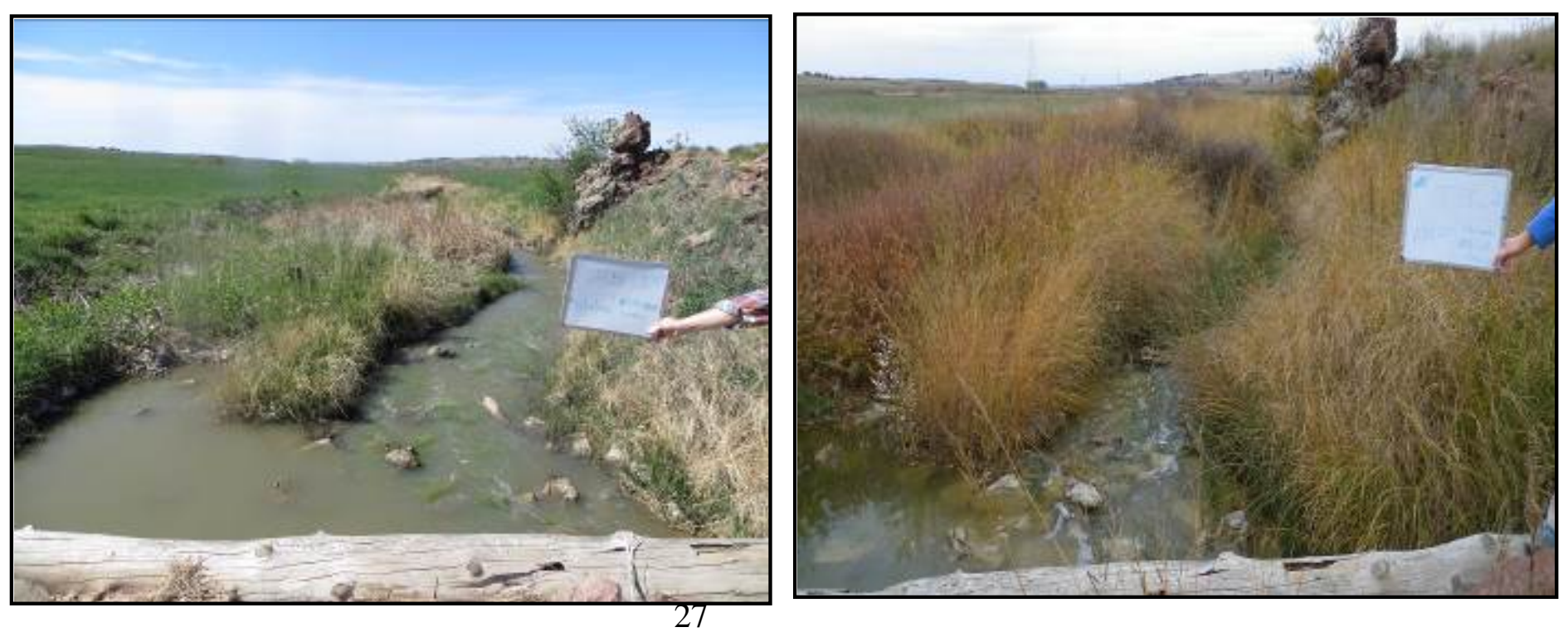


\section{Site Photos}

Otter Creek \#16 (Impact) spring (left) and fall (right) looking downstream from road crossing.
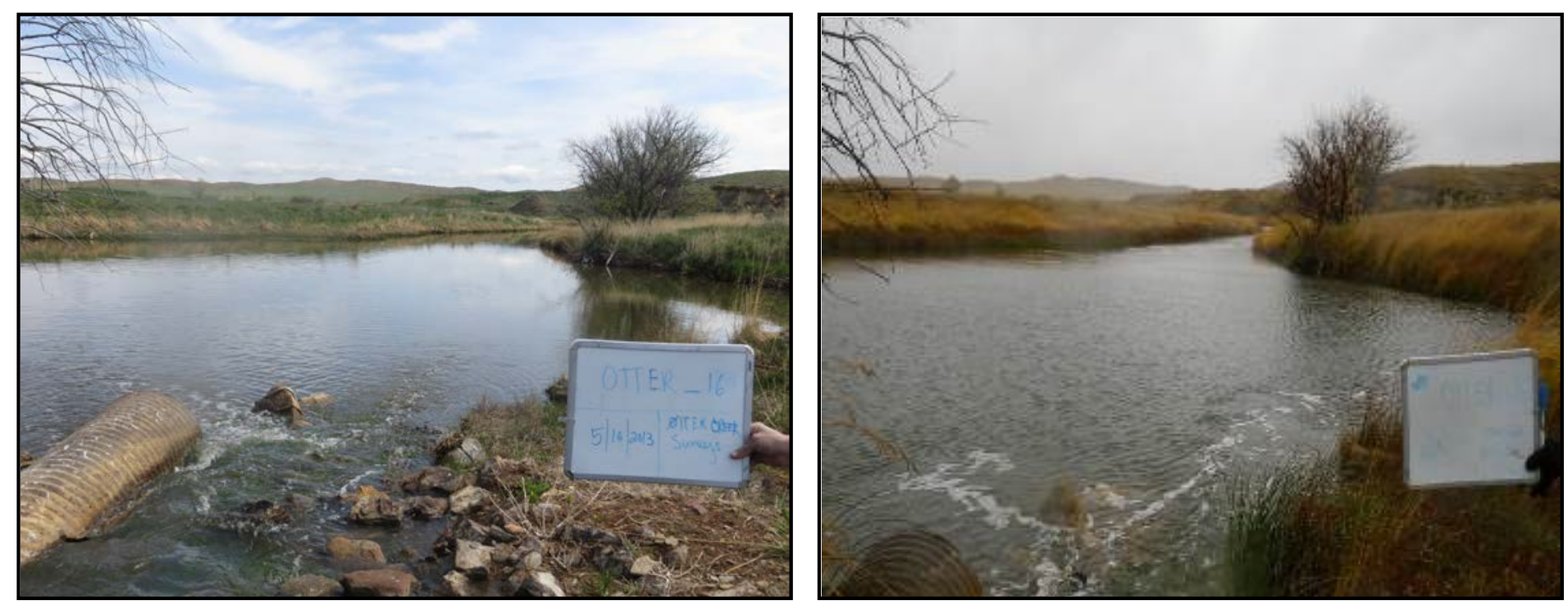

Northwestern Great Plains Intermittent Stream-(AES D005)-1) Home Creek 1A, 2) Tenmile Creek Home Creek (Otter 1A) during the spring (left) and fall (right) visits.
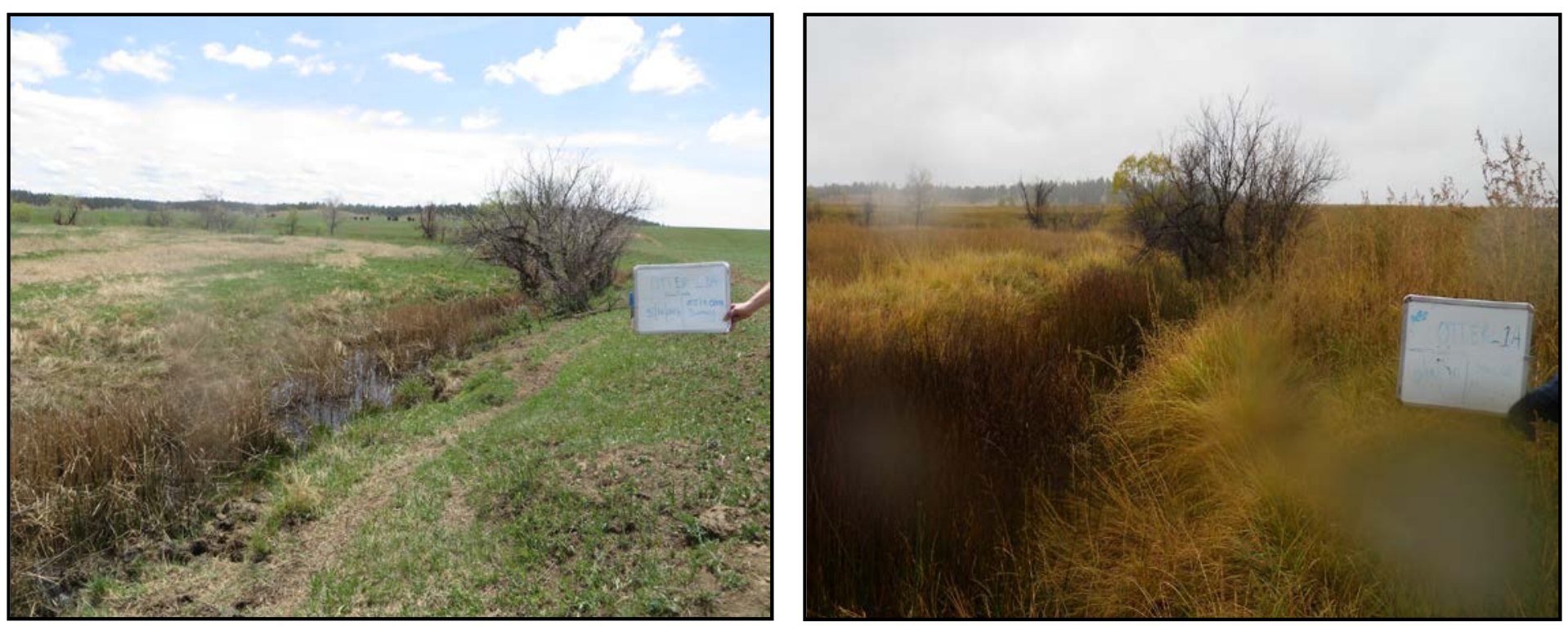


\section{Site Photos}

Home Creek (Otter 1A) during the summer (left) and fall (right) 2013 visits with a duckweed bloom
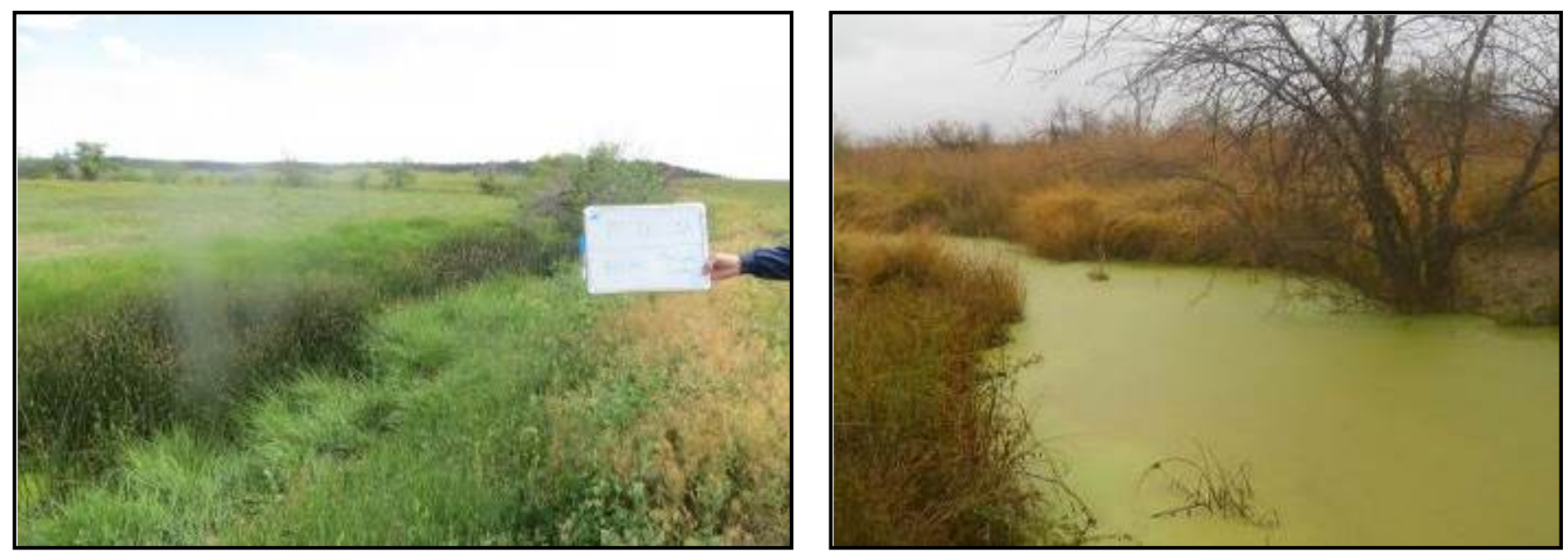

Great Plains Intermittent Fishless Prairie Stream (AES code E005)-1) Tenmile Creek, 2) Threemile Creek Tenmile Creek (Otter_23) in the spring (left) and summer (right) 2013 visits.
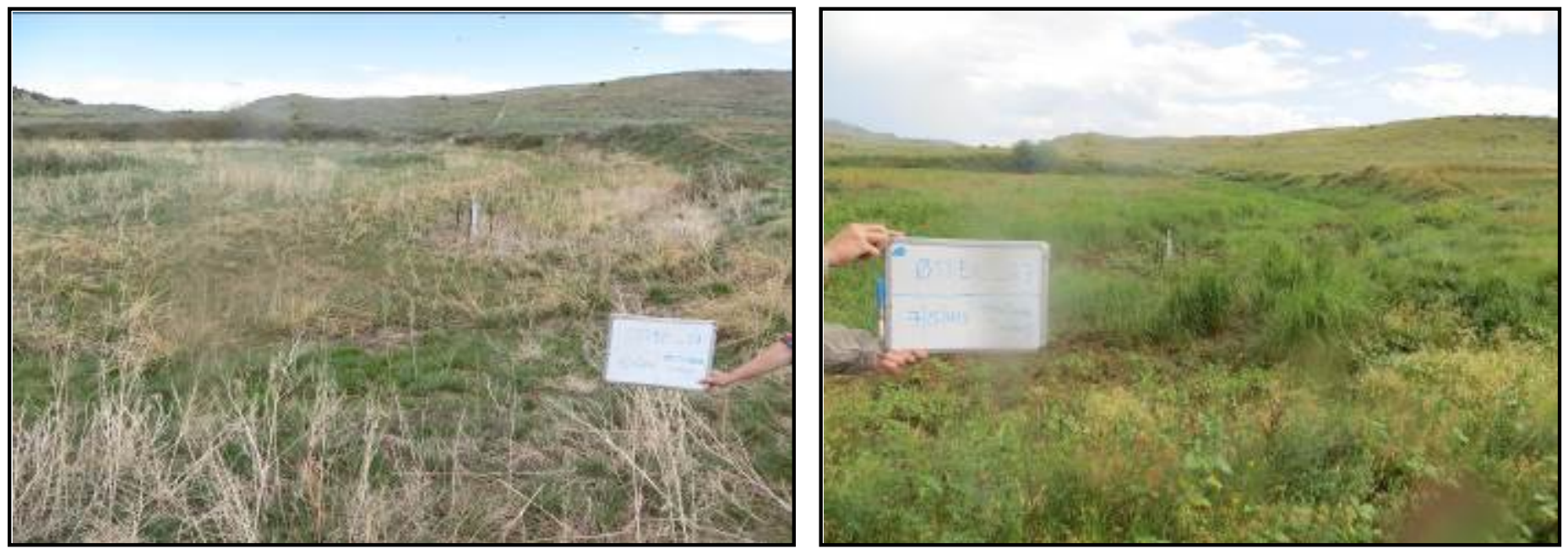

Site Photos: Threemile Creek (Otter 3m) during the spring (left) and summer (right) 2013 visits
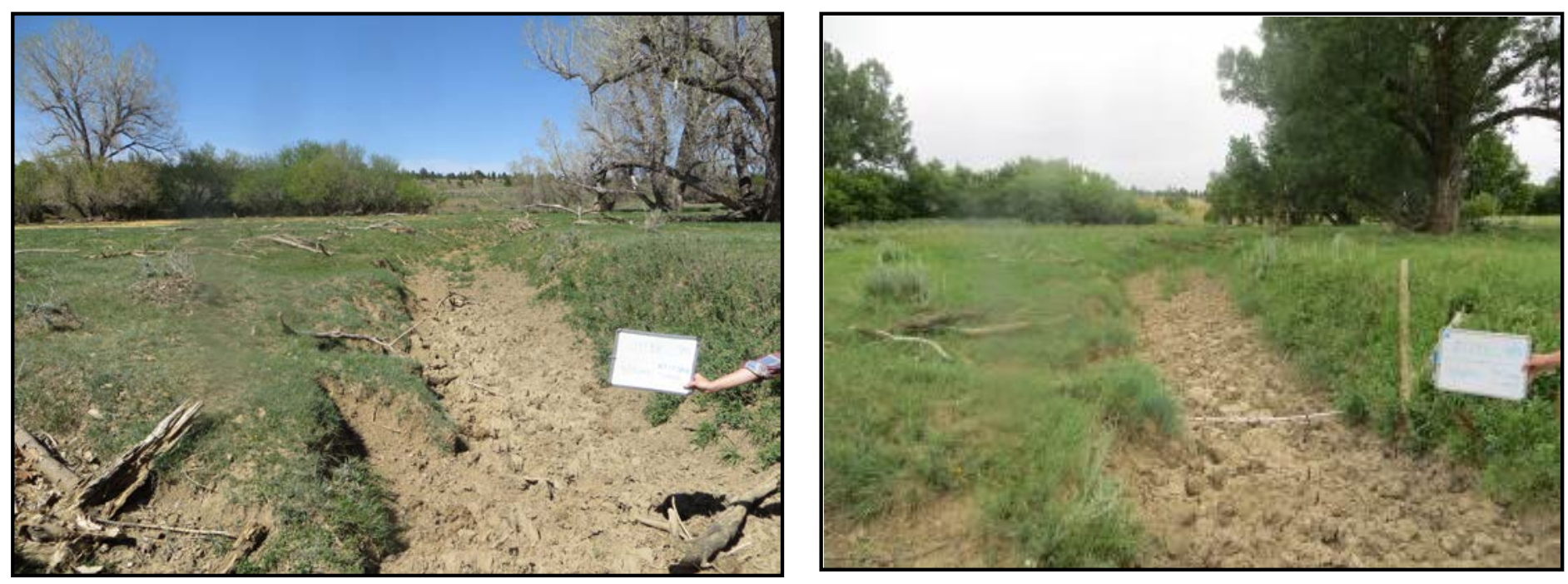


\section{Literature Cited}

Allan, J. D., D. L. Erickson and J. Fay. 1997. The Influence of Catchment Land Use on Stream Integrity Across Multiple Spatial Scales. Freshwater Biology 37:149-162.

Barbour, M., J. Gerritsen, B.D. Snyder, and J.B. Stribling. 1999. Rapid Bioassessment Protocols for Use in Streams and Wadable Rivers: Periphyton, Benthic Macroinvertebrates and Fish, Second Edition. EPA 841-B-99-002. United States Environmental Protection Agency; Office of Water: Washington, D.C.

BLM 2002. Bureau of Land Management. Environmental Assessment.

http://dnrc.mt.gov/Trust/MMB/OtterCreek/2General/TransferDocuments/BLMTransferEA.pdf

BLM 2008a. Standard Methods for Field Surveys of Macroinvertebrate Samples. http://www.usu.edu/buglab/Monitoring/fieldForms.cfm Bureau of Land Management/USU National Aquatic Monitoring Center, Logan, Utah.

BLM 2008b. Standard Methods for Laboratory Sample Sorting Procedures of Macroinvertebrate Samples. http://usu.edu/buglab/SampleProcessing/labProcedures.cfm Bureau of Land Management/USU National Aquatic Monitoring Center, Logan, Utah.

Bramblett, R. G., T. R. Johnson, A. V. Zale, A. V., and D. Heggem. 2005. Development and Evaluation of a Fish Assemblage Index of Biotic Integrity for Northwestern Great Plains. Transactions of the American Fisheries Society 134:624-640, 2005.

Bramblett, R. G., and K. D. Fausch. 1991. Variable fish communities and the index of biotic integrity in a western Great Plains river. Transactions of the American Fisheries Society 120:752-769.

Confluence Consulting, Inc. 2004. Powder River Biological Survey and Implications for Coalbed

Methane Development prepared for Powder River Basin Resource Council. 67 pp.+ appendicies.

Davis, W.N., Bramblett, R.G., Zale, A.V., and Endicott, C.L., 2009. A review of the potential effects of coal bed natural gas development activities on fish assemblages of the Powder River geologic basin: Reviews in Fisheries Science, v. 17, no. 3, p. 402-422.

Dodds, W. K., K. Gido, M. R. Whiles, K. M. Fritz, and W. J. Matthews. 2004. Life on the edge: The ecology of Great Plains prairie streams. BioScience 54: 205-216.

Farag, A.M., Harper, D.D., Senecal, A., and Hubert, W.A., 2010. Potential effects of coalbed natural gas development on fish and aquatic resources, in Reddy, K.J., ed., Coalbed Natural GasEnergy and Environment: New York, Nova Science Publishers, p. 227-242.

Feldman, D. 2006. Interpretation of New Macroinvertebrate Models by WQPB. Draft Report. Montana Department of Environmental Quality, Planning Prevention and 
Assistance Division, Water Quality Planning Bureau, Water Quality Standards Section.1520 E. $6^{\text {th }}$ Avenue, Helena, MT 59620. 14 pp.

George, M.R., R.E. Larsen, N.K. McDougald, K.W. Tate, J.D. Gerlach, Jr., and K.O. Fulgham. 2002. Influence of grazing on channel morphology of intermittent streams. J. Range Management. 55:551-557.

Hawkins, C. P. and R. H. Norris. 2000. Performance of different landscape classifications for aquatic bioassessments: introduction to the series. Journal of the North American Benthological Society.19:3 (367-369).

Holton, G. D., and H. E. Johnson. 2003. A field guide to Montana fishes, 3rd edition. Montana Fish, Wildlife, and Parks, Helena.

Jessup, B., J. Stribling; and C. Hawkins. 2005. Biological Indicators of Stream Condition in Montana Using Macroinvertebrates. Tetra Tech, Inc. November 2005 (draft).

Jessup, B. 2006. Ecological Data Application System (EDAS) Version MT 3.3.2k A User's Guide. Tetra Tech, Inc.

Karr, J. R. 1981. Assessment of biotic integrity using fish communities. Fisheries 6(6):21-27.

Lazorchak, J.M., D.J. Klemm and D.V. Peck (editors). 1998. Environmental Monitoring and Assessment Program - Surface Waters: Field Operations and Methods for Measuring the Ecological Condition of Wadeable Streams. EPA/620/R-94/004F. U.S. Environmental Protection Agency, Washington, D.C.

Lohr S.C. and K.D. Fausch 1997. Multiscale analysis of natural variability in stream fish assemblages of a western Great Plains watershed. Copeia 1997: 706-724.

Matthews, W.J., R.C. Cashner and F.P. Gelwick. 1988. Stability and persistence of fish faunas and assemblages in three Midwestern streams. Copeia 1988: 945-955.

Matthews, W.J. 1998. Patterns in Freshwater Fish Ecology. Chapman and Hall: New York.

Montana Department of Environmental Quality (DEQ). 2006. Sample Collection, Sorting, and Taxonomic Identification of Benthic Macroinvertebrates. Water Quality Planning Bureau. Standard Operation Procedure (WQPBWQM-009).

Montana Department of Environmental Quality (DEQ). 2006b. ADMINISTRATIVE RULES OF MONTANA 17.30.670. Chapter 30 Surface Water Quality Standards and Procedures. www.deq.mt.gov/dir/Legal/Chapters/Ch30-06.pdf

Maxell, B.A., 2009. Monitoring of amphibians and reptiles in the Powder and Tongue River Basins of Montana. Prepared for the Montana State Office of the Bureau of Land Management by the Montana Natural Heritage Program, University of Montana, Helena, MT. 
Peterson, D.A., Wright, P.R., Edwards, G.P., Jr., Hargett, E.G., Feldman, D.L., Zumberge, J.R., and Dey, P. 2009, Ecological assessment of streams in the Powder River structural basin, Wyoming and Montana, 2005-06: U.S. Geological Survey Scientific Investigations Report 2009-5023, $139 \mathrm{p}$.

Peterson, D.A., M.L. Clark, K. Foster, P.R. Wright, and G.K. Boughton 2010. Assessment of ecological conditions and potential effects of water produced from coalbed natural gas development on biological communities in streams of the Powder River structural basin, Wyoming and Montana, 2005-08: USGS Scientific Investigations Report 2010-5124, 84 p. http://pubs.usgs.gov/sir/2010/5124/pdf/SIR10-5124.pdf

Pflieger, W. L. 1997. The fishes of Missouri, revised edition. Missouri Department of Conservation, Jefferson City.

Pritchard, D., F. Barret, H. Berg, W. Hagenbuck, R. Krapf, R. Leinard, S. Leonard, M. Manning, C. Noble, D. Tippy. 1993. Riparian Area Management: A User Guide to Assessing Proper Functioning Condition. Technical Reference 1737-9. USDI Bureau of Land Management Service Center. Denver, Colorado. USA. 109 pp.

Scott, W. B., and E. J. Crossman. 1973. Freshwater fishes of Canada. Fisheries Research Board of Canada, Bulletin 184, Ottawa.

Stagliano, D. M. 2012. Baseline Assessments and Analysis of Fish, Macroinvertebrates and Herpetofauna in the Otter Creek Coal Tracts Area of Powder River County. Prepared for Westech Environmental Services, Helena Field Office. 30 pp.

Stagliano, David, M. 2011. Baseline Assessments for Fish, Macroinvertebrates, and Herpetofauna in the Headwaters of Otter and Hanging Woman Creeks within the Tongue Powder CBNG Area. Report to the Bureau of Land Management. Montana Natural Heritage Program, Helena, Montana. 17 pp. http://mtnhp.org/reports/CBNG TonguePowder.pdf

Stagliano, David, M. 2005. Aquatic Community Classification and Ecosystem Diversity in Montana's Missouri River Watershed. Report to the Bureau of Land Management. Montana Natural Heritage Program, Helena, Montana. 65 pp. plus appendices. http://www.mtnhp.org/reports.asp\#Ecology

USGS 2013. Annual Streamflow Station 06307740 Information for Otter Creek near Ashland, MT http://waterdata.usgs.gov/mt/nwis/uv?site no $=06307740$

USGS 2012. Annual Streamflow Station 06307740 Information for Otter Creek near Ashland, MT http://waterdata.usgs.gov/mt/nwis/uv?site no $=06307740$

USGS 2000. Fish Status Index and IBI Information for the NAWQA program. http://water.usgs.gov/nawqa/sumr/bioind/fish.pdf 
Spring 2013

\begin{tabular}{|c|c|c|c|c|c|c|c|c|c|c|c|c|}
\hline & Otter23 & & Otter22 & & Otter16 & & Otter2 & & OtterJT & & Otter1A & \\
\hline Black Bullhead & 0.0 & & 17.5 & & 148.8 & & 17.5 & & 0.0 & & 0.0 & \\
\hline Brassy Minnow & 0.0 & & 512.5 & & 108.5 & & 10.5 & & 12.5 & & 39.0 & \\
\hline Common Carp & 0.0 & & 0.0 & & 62.0 & & 0.0 & & 10.0 & & 0.0 & \\
\hline Fathead Minnow & 0.0 & & 27.5 & & 21.7 & & 42.0 & & 1317.5 & & 2.0 & \\
\hline Lake Chub & 0.0 & & 2825.0 & & 74.4 & & 210.0 & & 42.5 & & 0.0 & \\
\hline Green Sunfish & 0.0 & & 2.5 & & 6.2 & & 24.5 & & 0.0 & & 0.0 & \\
\hline Golden Shiner & 0.0 & & 0.0 & & 58.9 & & 0.0 & & 0.0 & & 0.0 & \\
\hline Pumpkinseed Sunfish & 0.0 & & 2.5 & & 52.7 & & 0.0 & & 0.0 & & 0.0 & \\
\hline Sand Shiner & 0.0 & & 0.0 & & 0.0 & & 0.0 & & 1060.0 & & 0.0 & \\
\hline White Sucker & 0.0 & & 265.0 & & 133.3 & & 24.5 & & 52.5 & & 0.0 & \\
\hline Total \# species & 0.0 & & 7.0 & & 9.0 & & 6.0 & & 6.0 & & 2.0 & \\
\hline Native Species & 0.0 & & 4.0 & & 4.0 & & 4.0 & & 5.0 & & 2.0 & \\
\hline Native Families & 0.0 & & 2.0 & & 2.0 & & 2.0 & & 2.0 & & 1.0 & \\
\hline Total Individuals & 0.0 & & 3652.5 & & 666.5 & & 329.0 & & 2495.0 & & 41.0 & \\
\hline $\begin{array}{l}\text { \# Minnow Species Thrive } \\
\text { Proportion of tolerant } \\
\text { individuals }\end{array}$ & $\begin{array}{l}0.0 \\
0.00\end{array}$ & & $\begin{array}{l}3.0 \\
8.56\end{array}$ & & $\begin{array}{r}3.0 \\
64.65\end{array}$ & & $\begin{array}{c}3.0 \\
32.98\end{array}$ & & $\begin{array}{r}4.0 \\
55.31\end{array}$ & & $\begin{array}{l}2.0 \\
4.88 \\
\end{array}$ & \\
\hline \# Sucker + Catfish Species & 0.0 & & 2.0 & & 2.0 & & 2.0 & & 1.0 & & 0.0 & \\
\hline$\%$ Insectivorous Minnows & 0.0 & & 77.3 & & 11.2 & & 63.8 & & 44.2 & & 0.0 & \\
\hline \# Benthic Invertivore Specie & 0.0 & & 1.0 & & 1.0 & & 1.0 & & 0.0 & & 0.0 & \\
\hline \% Litholphilic Spawners & 0.0 & & 7.3 & & 20.0 & & 7.4 & & 44.6 & & 0.0 & \\
\hline$\%$ Parental Care & 0.00 & & 1.23 & & 25.58 & & 18.09 & & 52.81 & & 4.88 & \\
\hline$\%$ Native to Montana & 0.0 & & 99.4 & & 50.7 & & 87.2 & & 99.6 & & 100.0 & \\
\hline \multirow[t]{2}{*}{ \# Long Lived Species } & 0.0 & & 4.0 & & 5.0 & & 1.0 & & 4.0 & & 2.0 & \\
\hline & Otter23 & & Otter22 & & Otter16 & & Otter2 & & OtterJT & & Otter1A & \\
\hline Metrics & $\begin{array}{l}\text { Adjust } \\
\text { Value }\end{array}$ & Score & $\begin{array}{l}\text { Adjust } \\
\text { Value }\end{array}$ & Score & \begin{tabular}{|l|} 
Adjust \\
Value \\
\end{tabular} & Score & \begin{tabular}{|l|} 
Adjust \\
Value
\end{tabular} & & $\begin{array}{l}\text { Adjust } \\
\text { Value } \\
\end{array}$ & Score & $\begin{array}{l}\text { Adjust } \\
\text { Value }\end{array}$ & Score \\
\hline $\begin{array}{l}\text { Number of Native Fish } \\
\text { Species to Montana }\end{array}$ & 11.6 & 64.7 & 10.3 & 57.4 & 10.1 & 56.0 & 10.0 & 55.3 & 10.8 & 59.9 & 13.3 & 73.7 \\
\hline $\begin{array}{l}\text { Number of Native Fish } \\
\text { Families to Montana }\end{array}$ & 2.1 & 39.5 & 3.2 & 58.7 & 3.1 & 57.8 & 3.1 & 57.4 & 3.1 & 56.8 & 3.1 & 56.7 \\
\hline $\begin{array}{l}\text { Proportion of tolerant } \\
\text { individuals }\end{array}$ & 0.0 & 100.0 & 8.6 & 90.9 & 64.7 & 31.6 & 33.0 & 65.1 & 55.3 & 41.5 & 4.9 & 94.8 \\
\hline $\begin{array}{l}\text { Number of Sucker and } \\
\text { Catfish Species }\end{array}$ & 7.1 & 77.1 & 5.9 & 64.2 & 5.8 & 62.6 & 5.7 & 61.8 & 4.6 & 49.8 & 6.9 & 74.7 \\
\hline $\begin{array}{l}\text { Proportion out of the Total } \\
\text { Number of Fish That Were } \\
\text { Insect eating Minnows }\end{array}$ & 0.0 & 0.0 & 77.3 & 106.2 & 11.2 & 15.3 & 63.8 & 87.7 & 44.2 & 60.7 & 0.0 & 0.0 \\
\hline $\begin{array}{l}\text { Total Number of Species That } \\
\text { Prefer to Eat Insects That Live } \\
\text { on the Stream Bottom }\end{array}$ & 5.5 & 93.1 & 4.0 & 68.3 & 4.9 & 83.3 & 4.8 & 82.4 & 4.8 & 81.0 & 5.3 & 90.2 \\
\hline $\begin{array}{l}\text { Proportion of the Total } \\
\text { Number of Fish That Require } \\
\text { Rocks to Lay Eggs }\end{array}$ & 0.0 & 0.0 & 7.3 & 8.7 & 20.0 & 24.1 & 7.4 & 9.0 & 44.6 & 53.8 & 0.0 & 0.0 \\
\hline $\begin{array}{l}\text { Proportion of the Total } \\
\text { Number of Individuals That } \\
\text { Do Not Require Rocks, But } \\
\text { Have Parental Care of Eggs }\end{array}$ & 0.0 & 100.0 & 1.2 & 98.6 & 25.6 & 70.9 & 18.1 & 79.4 & 52.8 & 39.9 & 4.9 & 94.5 \\
\hline $\begin{array}{l}\text { Proportion of the Total } \\
\text { Number of Fish Sampled } \\
\text { That Were Native to } \\
\text { Montana }\end{array}$ & 0.0 & 0.0 & 99.4 & 99.4 & 50.7 & 50.7 & 87.2 & 87.3 & 99.6 & 99.6 & 100.0 & 100.0 \\
\hline $\begin{array}{l}\text { Number of Long-Lived Native } \\
\text { Species }\end{array}$ & 8.5 & 86.9 & 5.7 & 58.1 & 9.5 & 97.3 & 5.4 & 55.4 & 8.3 & 84.9 & 10.2 & 104.7 \\
\hline & & 561.4 & & 710.6 & & 549.6 & & 640.9 & & 628.0 & & 689.5 \\
\hline IBI Score & & 56.14 & & 71.06 & & 54.96 & & 64.09 & & 62.80 & & 68.95 \\
\hline
\end{tabular}


Summer 2013

\begin{tabular}{|c|c|c|c|c|c|c|c|c|c|c|c|c|}
\hline & Otter23 & & Otter22 & & Otter16 & & Otter2 & & OtterJT & & Otter1A & \\
\hline Black Bullhead & 0.0 & & 351.0 & & 595.2 & & 7.0 & & 0.0 & & 0.0 & \\
\hline Brassy Minnow & 0.0 & & 669.6 & & 434.0 & & 52.5 & & 15.0 & & 44.0 & \\
\hline Common Carp & 0.0 & & 0.0 & & 248.0 & & 10.5 & & 23.0 & & 0.0 & \\
\hline Fathead Minnow & 0.0 & & 0.0 & & 86.8 & & 35.0 & & 1085.0 & & 12.0 & \\
\hline Lake Chub & 0.0 & & 945.0 & & 297.6 & & 14.0 & & 75.0 & & 0.0 & \\
\hline Green Sunfish & 0.0 & & 35.1 & & 24.8 & & 3.5 & & 0.0 & & 0.0 & \\
\hline Golden Shiner & 0.0 & & 0.0 & & 235.6 & & 0.0 & & 0.0 & & 0.0 & \\
\hline Pumpkinseed Sunfish & 0.0 & & 32.4 & & 210.8 & & 0.0 & & 0.0 & & 0.0 & \\
\hline Sand Shiner & 0.0 & & 0.0 & & 0.0 & & 3.5 & & 900.0 & & 0.0 & \\
\hline White Sucker & 0.0 & & 159.3 & & 533.2 & & 3.5 & & 98.0 & & 0.0 & \\
\hline Total \# species & 0.0 & & 6.0 & & 9.0 & & 8.0 & & 6.0 & & 2.0 & \\
\hline Native Species & 0.0 & & 3.0 & & 4.0 & & 5.0 & & 5.0 & & 2.0 & \\
\hline Native Families & 0.0 & & 2.0 & & 2.0 & & 2.0 & & 2.0 & & 1.0 & \\
\hline Total Individuals & 0.0 & & 2192.4 & & 2666.0 & & 129.5 & & 2196.0 & & 56.0 & \\
\hline \# Minnow Species Thrive & 0.0 & & 2.0 & & 3.0 & & 4.0 & & 4.0 & & 2.0 & \\
\hline $\begin{array}{l}\text { Proportion of tolerant } \\
\text { individuals }\end{array}$ & & & & & 64.65 & & 45.95 & & 54.92 & & 21.43 & \\
\hline \# Sucker + Catfish Species & 0.0 & & 2.0 & & 2.0 & & 2.0 & & 1.0 & & 0.0 & \\
\hline$\%$ Insectivorous Minnows & 0.0 & & 43.1 & & 11.2 & & 13.5 & & 44.4 & & 0.0 & \\
\hline \# Benthic Invertivore Species & 0.0 & & 1.0 & & 1.0 & & 1.0 & & 0.0 & & 0.0 & \\
\hline \% Litholphilic Spawners & 0.0 & & 7.3 & & 20.0 & & 5.4 & & 45.4 & & 0.0 & \\
\hline$\%$ Parental Care & 0.00 & & 16.01 & & 25.58 & & 32.43 & & 49.41 & & 21.43 & \\
\hline$\%$ Native to Montana & 0.0 & & 80.9 & & 50.7 & & 83.8 & & 99.0 & & 100.0 & \\
\hline \multirow[t]{2}{*}{ \# Long Lived Species } & 0.0 & & 1.0 & & 2.0 & & 1.0 & & 4.0 & & 1.0 & \\
\hline & Otter23 & & Otter22 & & Otter16 & & Otter2 & & OtterJT & & Otter1A & \\
\hline Metrics & $\begin{array}{l}\text { Adjust } \\
\text { Value }\end{array}$ & & $\begin{array}{l}\text { Adjust } \\
\text { Value }\end{array}$ & & $\begin{array}{l}\text { Adjust } \\
\text { Value }\end{array}$ & & $\begin{array}{l}\text { Adjust } \\
\text { Value }\end{array}$ & & $\begin{array}{l}\text { Adjust } \\
\text { Value }\end{array}$ & & $\begin{array}{l}\text { Adjust } \\
\text { Value }\end{array}$ & Score \\
\hline $\begin{array}{l}\text { Number of Native Fish Species } \\
\text { to Montana }\end{array}$ & 11.6 & 64.7 & 9.3 & 51.8 & 10.1 & 56.0 & 11.1 & 61.5 & 10.8 & 59.9 & 13.3 & 73.7 \\
\hline $\begin{array}{l}\text { Number of Native Fish Families } \\
\text { to Montana }\end{array}$ & 2.1 & 39.5 & 3.2 & 58.7 & 3.1 & 57.8 & 3.1 & 57.8 & 3.1 & 56.8 & 3.1 & 56.7 \\
\hline $\begin{array}{l}\text { Proportion of tolerant } \\
\text { individuals }\end{array}$ & 0.0 & 100.0 & 24.9 & 73.7 & 64.7 & 31.6 & 45.9 & 51.4 & 54.9 & 41.9 & 21.4 & 77.3 \\
\hline $\begin{array}{l}\text { Number of Sucker and Catfish } \\
\text { Species }\end{array}$ & 7.1 & 77.1 & 5.9 & 64.2 & 5.8 & 62.6 & 5.8 & 62.6 & 4.6 & 49.8 & 6.9 & 74.7 \\
\hline $\begin{array}{l}\text { Proportion out of the Total } \\
\text { Number of Fish That Were } \\
\text { Insect eating Minnows }\end{array}$ & 0.0 & 0.0 & 43.1 & 59.2 & 11.2 & 15.3 & 13.5 & 18.6 & 44.4 & 61.0 & 0.0 & 0.0 \\
\hline $\begin{array}{l}\text { Total Number of Species That } \\
\text { Prefer to Eat Insects That Live } \\
\text { on the Stream Bottom }\end{array}$ & 5.5 & 93.1 & 4.0 & 68.3 & 4.9 & 83.3 & 4.9 & 83.3 & 4.8 & 81.0 & 5.3 & 90.2 \\
\hline $\begin{array}{l}\text { Proportion of the Total } \\
\text { Number of Fish That Require } \\
\text { Rocks to Lay Eggs }\end{array}$ & 0.0 & 0.0 & 7.3 & 8.8 & 20.0 & 24.1 & 5.4 & 6.5 & 45.4 & 54.8 & 0.0 & 0.0 \\
\hline \begin{tabular}{|l|} 
Proportion of the Total \\
Number of Individuals That Do \\
Not Require Rocks, But Have \\
Parental Care of Eggs
\end{tabular} & 0.0 & 100.0 & 16.0 & 81.8 & 25.6 & 70.9 & 32.4 & 63.1 & 49.4 & 43.8 & 21.4 & 75.6 \\
\hline $\begin{array}{l}\text { Proportion of the Total } \\
\text { Number of Fish Sampled That } \\
\text { Were Native to Montana }\end{array}$ & 0.0 & 0.0 & 80.9 & 80.9 & 50.7 & 50.7 & 83.8 & 83.8 & 99.0 & 99.0 & 100.0 & 100.0 \\
\hline $\begin{array}{l}\text { Number of Long-Lived Native } \\
\text { Species }\end{array}$ & 8.5 & 86.9 & 5.7 & 58.1 & 6.5 & 66.5 & 5.5 & 56.3 & 8.3 & 84.9 & 9.2 & 94.5 \\
\hline & & 561.4 & & 605.5 & & 518.9 & & 544.9 & & 632.9 & & 642.9 \\
\hline IBI Score & & 56.14 & & 60.55 & & 51.89 & & 54.49 & & 63.29 & & 64.29 \\
\hline
\end{tabular}


Appendix A. (cont.) Rawdata and IBI metric calculation from fish data collected from Otter Creek Coal Tract Sites

Fall 2013

\begin{tabular}{|c|c|c|c|c|c|c|c|c|c|c|c|c|}
\hline & Otter23 & & Otter22 & & Otter16 & & Otter2 & & OtterJT & & Otter1A & \\
\hline Black Bullhead & 0.0 & & 0.0 & & 18.0 & & 0.0 & & 2.0 & & 0.0 & \\
\hline Brassy Minnow & 0.0 & & 88.0 & & 6.0 & & 60.0 & & 2.0 & & 32.0 & \\
\hline Common Carp & 0.0 & & 0.0 & & 189.0 & & 7.5 & & 14.0 & & 0.0 & \\
\hline Fathead Minnow & 0.0 & & 15.4 & & 6.0 & & 0.0 & & 774.0 & & 0.0 & \\
\hline Lake Chub & 0.0 & & 79.2 & & 0.0 & & 26.3 & & 4.0 & & 8.0 & \\
\hline Green Sunfish & 0.0 & & 28.6 & & 0.0 & & 7.5 & & 0.0 & & 0.0 & \\
\hline Golden Shiner & 0.0 & & 0.0 & & 0.0 & & 0.0 & & 0.0 & & 0.0 & \\
\hline Pumpkinseed Sunfish & 0.0 & & 19.8 & & 90.0 & & 0.0 & & 10.0 & & 0.0 & \\
\hline Sand Shiner & 0.0 & & 0.0 & & 0.0 & & 0.0 & & 234.0 & & 0.0 & \\
\hline White Sucker & 0.0 & & 15.4 & & 0.0 & & 0.0 & & 54.0 & & 0.0 & \\
\hline Total \# species & 0.0 & & 6.0 & & 5.0 & & 4.0 & & 8.0 & & 2.0 & \\
\hline Native Species & 0.0 & & 4.0 & & 2.0 & & 2.0 & & 5.0 & & 2.0 & \\
\hline Native Families & 0.0 & & 2.0 & & 2.0 & & 2.0 & & 2.0 & & 1.0 & \\
\hline Total Individuals & 0.0 & & 246.4 & & 309.0 & & 101.3 & & 1094.0 & & 40.0 & \\
\hline $\begin{array}{l}\text { \# Minnow Species Thrive } \\
\text { Proportion of tolerant } \\
\text { individuals }\end{array}$ & $\begin{array}{l}0.0 \\
0.00\end{array}$ & & $\begin{array}{r}3.0 \\
24.11 \\
\end{array}$ & & $\begin{array}{r}2.0 \\
68.93 \\
\end{array}$ & & $\begin{array}{r}2.0 \\
14.81 \\
\end{array}$ & & $\begin{array}{r}4.0 \\
77.15 \\
\end{array}$ & & $\begin{array}{l}2.0 \\
0.00\end{array}$ & \\
\hline \# Sucker + Catfish Species & 0.0 & & 1.0 & & 1.0 & & 0.0 & & 2.0 & & 0.0 & \\
\hline$\%$ Insectivorous Minnows & 0.0 & & 32.1 & & 0.0 & & 25.9 & & 21.8 & & 20.0 & \\
\hline \# Benthic Invertivore Species & 0.0 & & 0.0 & & 1.0 & & 0.0 & & 1.0 & & 0.0 & \\
\hline \% Litholphilic Spawners & 0.0 & & 6.3 & & 0.0 & & 0.0 & & 26.3 & & 0.0 & \\
\hline$\%$ Parental Care & 0.00 & & 6.25 & & 7.77 & & 0.00 & & 70.93 & & 0.00 & \\
\hline$\%$ Native to Montana & 0.0 & & 80.4 & & 3.9 & & 85.2 & & 97.6 & & 100.0 & \\
\hline \multirow[t]{2}{*}{ \# Long Lived Species } & 0.0 & & 6.0 & & 4.0 & & 3.0 & & 6.0 & & 2.0 & \\
\hline & Otter23 & & Otter22 & & Otter16 & & Otter2 & & OtterJT & & Otter1A & \\
\hline Metrics & \begin{tabular}{|l|} 
Adjust \\
Value \\
\end{tabular} & & \begin{tabular}{|l|} 
Adjust \\
Value \\
\end{tabular} & & \begin{tabular}{|l|}
$\begin{array}{l}\text { Adjust } \\
\text { Value }\end{array}$ \\
\end{tabular} & & \begin{tabular}{|l|} 
Adjust \\
Value \\
\end{tabular} & & $\begin{array}{l}\text { Adjust } \\
\text { Value } \\
\end{array}$ & & $\begin{array}{l}\text { Adjust } \\
\text { Value } \\
\end{array}$ & Score \\
\hline $\begin{array}{l}\text { Number of Native Fish Species } \\
\text { to Montana }\end{array}$ & 11.6 & 64.7 & 10.3 & 57.4 & 8.1 & 44.9 & 8.1 & 44.9 & 10.8 & 59.9 & 13.3 & 73.7 \\
\hline $\begin{array}{l}\text { Number of Native Fish Families } \\
\text { to Montana }\end{array}$ & 2.1 & 39.5 & 3.2 & 58.7 & 3.1 & 57.8 & 3.1 & 57.8 & 3.1 & 56.8 & 3.1 & 56.7 \\
\hline $\begin{array}{l}\text { Proportion of tolerant } \\
\text { individuals }\end{array}$ & 0.0 & 100.0 & 24.1 & 74.5 & 68.9 & 27.1 & 14.8 & 84.3 & 77.1 & 18.4 & 0.0 & 100.0 \\
\hline $\begin{array}{l}\text { Number of Sucker and Catfish } \\
\text { Species }\end{array}$ & 7.1 & 77.1 & 4.9 & 53.3 & 4.8 & 51.7 & 3.8 & 40.8 & 5.6 & 60.7 & 6.9 & 74.7 \\
\hline $\begin{array}{l}\text { Proportion out of the Total } \\
\text { Number of Fish That Were } \\
\text { Insect eating Minnows }\end{array}$ & 0.0 & 0.0 & 32.1 & 44.1 & 0.0 & 0.0 & 25.9 & 35.6 & 21.8 & 29.9 & 20.0 & 27.5 \\
\hline $\begin{array}{l}\text { Total Number of Species That } \\
\text { Prefer to Eat Insects That Live } \\
\text { on the Stream Bottom }\end{array}$ & 5.5 & 93.1 & 3.0 & 51.3 & 4.9 & 83.3 & 4.9 & 83.3 & 4.8 & 81.0 & 5.3 & 90.2 \\
\hline $\begin{array}{l}\text { Proportion of the Total } \\
\text { Number of Fish That Require } \\
\text { Rocks to Lay Eggs }\end{array}$ & 0.0 & 0.0 & 6.3 & 7.5 & 0.0 & 0.0 & 0.0 & 0.0 & 26.3 & 31.7 & 0.0 & 0.0 \\
\hline $\begin{array}{l}\text { Proportion of the Total } \\
\text { Number of Individuals That Do } \\
\text { Not Require Rocks, But Have } \\
\text { Parental Care of Eggs }\end{array}$ & 0.0 & 100.0 & 6.3 & 92.9 & 7.8 & 91.2 & 0.0 & 100.0 & 70.9 & 19.3 & 0.0 & 100.0 \\
\hline $\begin{array}{l}\text { Proportion of the Total } \\
\text { Number of Fish Sampled That } \\
\text { Were Native to Montana }\end{array}$ & 0.0 & 0.0 & 80.4 & 80.4 & 3.9 & 3.9 & 85.2 & 85.2 & 97.6 & 97.7 & 100.0 & 100.0 \\
\hline $\begin{array}{l}\text { Number of Long-Lived Native } \\
\text { Species }\end{array}$ & 8.5 & 86.9 & 5.7 & 58.1 & 8.5 & 87.0 & 7.5 & 76.8 & 10.3 & 105.3 & 10.2 & 104.7 \\
\hline & & 561.4 & & 578.2 & & 446.9 & & 608.8 & & 560.8 & & 727.7 \\
\hline IBI Score & & 56.14 & & 57.82 & & 44.69 & & 60.88 & & 56.08 & & 72.77 \\
\hline
\end{tabular}




\section{Appendix B}

Macroinvertebate taxa lists, abundance and metrics for the Otter Creek collection sites 


\section{Montana Bioassessment Report}

Waterbody Name: Otter Creek Site 16 for the Coal Tracts Study Station ID: OTTER_16t2

Reference Status:

Site Classification:

Latitude: Longitude:
Benthic Sample ID: 18127

Rep. Num 0

STORET Activity ID: OTTR16M-MAC-R

Collection Date: $\quad$ 05/19/2013

Collection Method: MAC-R-500

Total Number of Individuals in Sample: 1224

\section{Sample Taxa List}

\begin{tabular}{|c|c|c|c|c|c|c|}
\hline Order: & OTU name: & FinalID: & Individuals & Tol Val: & $F F G$ : & Habit: \\
\hline Amphipoda & Hyalella & Hyalella azteca & 160 & 8 & CG & SW/SP \\
\hline Basommatop & Lymnaeidae & Stagnicola caperata & 40 & 6 & CG & $\mathrm{CN}$ \\
\hline Basommatop & Physa_Physella & Physella acuta & 120 & 8 & CG & $\mathrm{CN}$ \\
\hline Basommatop & Planorbidae & Gyraulus parvus & 40 & 6 & CG & $\mathrm{CN}$ \\
\hline Coleoptera & Dubiraphia & Dubiraphia vittata & 96 & 6 & $\mathrm{SC} / \mathrm{CG}$ & "CN/50\%, BU/50\%" \\
\hline Diptera & Chironominae & Chironomus & 80 & 7 & $\mathrm{CG} / \mathrm{CF} / \mathrm{PR}$ & $\mathrm{BU} / \mathrm{CN} / \mathrm{SP}$ \\
\hline Diptera & Chironominae & Dicrotendipes & 8 & 7 & $\mathrm{CG} / \mathrm{CF} / \mathrm{PR}$ & $\mathrm{BU} / \mathrm{CN} / \mathrm{SP}$ \\
\hline Diptera & Chironominae & Polypedilum & 40 & 7 & $\mathrm{CG} / \mathrm{CF} / \mathrm{PR}$ & $\mathrm{BU} / \mathrm{CN} / \mathrm{SP}$ \\
\hline Diptera & Chironominae & Pseudochironomus & 8 & 7 & $\mathrm{CG} / \mathrm{CF} / \mathrm{PR}$ & $\mathrm{BU} / \mathrm{CN} / \mathrm{SP}$ \\
\hline Diptera & Chironominae & Tanytarsus & 80 & 7 & $\mathrm{CG} / \mathrm{CF} / \mathrm{PR}$ & $\mathrm{BU} / \mathrm{CN} / \mathrm{SP}$ \\
\hline Diptera & Orthocladiinae & Cricotopus & 16 & & CG/SC & SP/BU \\
\hline Diptera & Orthocladiinae & Psectrocladius & 40 & & CG/SC & SP/BU \\
\hline Diptera & Simuliidae & Simulium & 8 & 6 & CF & $\mathrm{CN}$ \\
\hline Diptera & Tanypodinae & Ablabesmyia & 16 & & PR & SP/BU \\
\hline Diptera & Tanypodinae & Procladius & 80 & & PR & SP/BU \\
\hline Ephemeropte & Caenis & Caenis latipennis & 56 & 8 & $C G$ & "SP/75\%, CM/90\%" \\
\hline Ephemeropte & Callibaetis & Callibaetis & 16 & 9 & CG & "SW/10\%, CN/90\%" \\
\hline Haplotaxida & Oligochaeta & Tubificidae & 40 & 8 & CG & $\mathrm{BU}$ \\
\hline Hemiptera & Corixidae & Corixidae & 40 & 9 & $\mathrm{PH} / \mathrm{PR}$ & SW \\
\hline Odonata & Coenagrionidae & Enallagma & 40 & 7 & PR & $\mathrm{CM}$ \\
\hline Odonata & Coenagrionidae & Ischnura & 32 & 7 & PR & $\mathrm{CM}$ \\
\hline Odonata & Lestes & Lestes dryas & 32 & 9 & PR & SW \\
\hline Odonata & Libellulidae & Libellula forensis & 48 & 9 & PR & SP \\
\hline Odonata & Libellulidae & Sympetrum & 8 & 9 & PR & SP \\
\hline Trichoptera & Cheumatopsyche & Cheumatopsyche & 40 & 5 & $\mathrm{CF}$ & $\mathrm{CN}$ \\
\hline Trichoptera & Chimarra & Chimarra & 8 & 4 & $\mathrm{CF}$ & $\mathrm{CN}$ \\
\hline Trichoptera & Limnephilus & Limnephilus & 32 & 3 & $\mathrm{SH}$ & $\mathrm{CM} / \mathrm{SP}$ \\
\hline
\end{tabular}




\section{Montana Bioassessment Report}

Waterbody Name: Otter Creek Site 16 for the Coal Tracts Study Station ID: OTTER_16t2f

Reference Status:

Site Classification:

Latitude: Longitude:
Benthic Sample ID: 18128

Rep. Num 0

STORET Activity ID: $\quad$ OTR16fM-MAC-R

Collection Date: $\quad$ 10/14/2013

Collection Method: MAC-R-500

Total Number of Individuals in Sample: $\quad 528$

\section{Sample Taxa List}

\begin{tabular}{|c|c|c|c|c|c|c|}
\hline \multirow[t]{3}{*}{ Order: } & \multirow[t]{3}{*}{ OTU name: } & FinalID: & \multirow{2}{*}{$\begin{array}{c}\text { Individuals } \\
12\end{array}$} & \multirow[t]{3}{*}{ Tol Val: } & \multirow[t]{3}{*}{$F F G:$} & \multirow[t]{3}{*}{ Habit: } \\
\hline & & Gyraulus circumstriatus & & & & \\
\hline & & Leucorrhinia intacta & 2 & & & \\
\hline Amphipoda & Hyalella & Hyalella azteca & 54 & 8 & CG & SW/SP \\
\hline Basommatop & Lymnaeidae & Stagnicola caperata & 10 & 6 & CG & $\mathrm{CN}$ \\
\hline Basommatop & Physa_Physella & Physella acuta & 43 & 8 & CG & $\mathrm{CN}$ \\
\hline Basommatop & Planorbidae & Gyraulus parvus & 6 & 6 & CG & $\mathrm{CN}$ \\
\hline Coleoptera & Dubiraphia & Dubiraphia vittata & 55 & 6 & $\mathrm{SC} / \mathrm{CG}$ & "CN/50\%, BU/50\%" \\
\hline Diptera & Ceratopogoninae & Culicoides & 4 & 6 & $\mathrm{PR} / \mathrm{CG}$ & SP/BU/SW \\
\hline Diptera & Ceratopogoninae & Probezzia & 4 & 6 & $\mathrm{PR} / \mathrm{CG}$ & $\mathrm{SP} / \mathrm{BU} / \mathrm{SW}$ \\
\hline Diptera & Chironominae & Chironomus & 40 & 7 & $\mathrm{CG} / \mathrm{CF} / \mathrm{PR}$ & $\mathrm{BU} / \mathrm{CN} / \mathrm{SP}$ \\
\hline Diptera & Chironominae & Dicrotendipes & 15 & 7 & CG/CF/PR & $\mathrm{BU} / \mathrm{CN} / \mathrm{SP}$ \\
\hline Diptera & Chironominae & Polypedilum & 14 & 7 & CG/CF/PR & $\mathrm{BU} / \mathrm{CN} / \mathrm{SP}$ \\
\hline Diptera & Chironominae & Pseudochironomus & 10 & 7 & CG/CF/PR & $\mathrm{BU} / \mathrm{CN} / \mathrm{SP}$ \\
\hline Diptera & Chironominae & Tanytarsus & 21 & 7 & CG/CF/PR & $\mathrm{BU} / \mathrm{CN} / \mathrm{SP}$ \\
\hline Diptera & Dasyheleinae & Dasyhelea & 4 & & CG & $\mathrm{BU} / \mathrm{SW}$ \\
\hline Diptera & Orthocladiinae & Cricotopus & 20 & & CG/SC & SP/BU \\
\hline Diptera & Orthocladiinae & Psectrocladius & 10 & & CG/SC & SP/BU \\
\hline Diptera & Simuliidae & Simulium & 4 & 6 & $\mathrm{CF}$ & $\mathrm{CN}$ \\
\hline Diptera & Tanypodinae & Ablabesmyia & 2 & & PR & $\mathrm{SP} / \mathrm{BU}$ \\
\hline Diptera & Tanypodinae & Procladius & 20 & & PR & SP/BU \\
\hline Ephemeropte & Caenis & Caenis latipennis & 75 & 8 & CG & "SP/75\%, CM/90\%" \\
\hline Ephemeropte & Callibaetis & Callibaetis & 2 & 9 & CG & "SW/10\%, CN/90\%" \\
\hline Haplotaxida & Oligochaeta & Tubificidae & 6 & 8 & CG & $\mathrm{BU}$ \\
\hline Hemiptera & Corixidae & Corixidae & 20 & 9 & $\mathrm{PH} / \mathrm{PR}$ & SW \\
\hline Odonata & Coenagrionidae & Enallagma & 14 & 7 & PR & $\mathrm{CM}$ \\
\hline Odonata & Coenagrionidae & Ischnura & 10 & 7 & PR & $\mathrm{CM}$ \\
\hline Odonata & Lestes & Lestes dryas & 4 & 9 & PR & SW \\
\hline Odonata & Libellulidae & Sympetrum & 2 & 9 & PR & SP \\
\hline Trichoptera & Cheumatopsyche & Cheumatopsyche & 35 & 5 & CF & $\mathrm{CN}$ \\
\hline Trichoptera & Chimarra & Chimarra & 4 & 4 & CF & $\mathrm{CN}$ \\
\hline Trichoptera & Limnephilus & Limnephilus & 4 & 3 & $\mathrm{SH}$ & $\mathrm{CM} / \mathrm{SP}$ \\
\hline Trombidiform & Acarina & Hydrodroma & 2 & 5 & PR & "SW/10\%, CN/90\%" \\
\hline
\end{tabular}




\section{Montana Bioassessment Report}

Waterbody Name: Otter Creek Site 16 for the Coal Tracts Study Station ID: OTTER_16t2s

Reference Status:

Site Classification:

Latitude: Longitude:
Benthic Sample ID: 18129

Rep. Num 0

STORET Activity ID: OTR16sM-MAC-R

Collection Date: $\quad$ 07/16/2013

Collection Method: MAC-R-500

Total Number of Individuals in Sample: $\quad 534$

\section{Sample Taxa List}

\begin{tabular}{|c|c|c|c|c|c|c|}
\hline Order: & OTU name: & $\begin{array}{l}\text { FinalID: } \quad \text { In } \\
\text { Gyraulus circumstriatus }\end{array}$ & $\begin{array}{c}\text { Individuals } \\
4\end{array}$ & Tol Val: & $F F G:$ & Habit: \\
\hline Amphipoda & Hyalella & Hyalella azteca & 22 & 8 & CG & SW/SP \\
\hline Basommatop & Lymnaeidae & Pseudosuccinea columella & 2 & 6 & CG & $\mathrm{CN}$ \\
\hline Basommatop & Lymnaeidae & Stagnicola caperata & 10 & 6 & CG & $\mathrm{CN}$ \\
\hline Basommatop & Physa_Physella & Physella acuta & 26 & 8 & CG & $\mathrm{CN}$ \\
\hline Basommatop & Planorbidae & Gyraulus parvus & 4 & 6 & CG & $\mathrm{CN}$ \\
\hline Coleoptera & Dubiraphia & Dubiraphia vittata & 4 & 6 & $\mathrm{SC} / \mathrm{CG}$ & "CN/50\%, BU/50\%" \\
\hline Diptera & Ceratopogoninae & Probezzia & 4 & 6 & $\mathrm{PR} / \mathrm{CG}$ & SP/BU/SW \\
\hline Diptera & Chironominae & Chironomus & 70 & 7 & $\mathrm{CG} / \mathrm{CF} / \mathrm{PR}$ & $\mathrm{BU} / \mathrm{CN} / \mathrm{SP}$ \\
\hline Diptera & Chironominae & Cryptochironomus & 4 & 7 & $\mathrm{CG} / \mathrm{CF} / \mathrm{PR}$ & $\mathrm{BU} / \mathrm{CN} / \mathrm{SP}$ \\
\hline Diptera & Chironominae & Dicrotendipes & 6 & 7 & $\mathrm{CG} / \mathrm{CF} / \mathrm{PR}$ & $\mathrm{BU} / \mathrm{CN} / \mathrm{SP}$ \\
\hline Diptera & Chironominae & Glyptotendipes & 24 & 7 & $\mathrm{CG} / \mathrm{CF} / \mathrm{PR}$ & $\mathrm{BU} / \mathrm{CN} / \mathrm{SP}$ \\
\hline Diptera & Chironominae & Phaenopsectra & 16 & 7 & $\mathrm{CG} / \mathrm{CF} / \mathrm{PR}$ & $\mathrm{BU} / \mathrm{CN} / \mathrm{SP}$ \\
\hline Diptera & Chironominae & Polypedilum & 6 & 7 & $\mathrm{CG} / \mathrm{CF} / \mathrm{PR}$ & $\mathrm{BU} / \mathrm{CN} / \mathrm{SP}$ \\
\hline Diptera & Chironominae & Pseudochironomus & 4 & 7 & $\mathrm{CG} / \mathrm{CF} / \mathrm{PR}$ & $\mathrm{BU} / \mathrm{CN} / \mathrm{SP}$ \\
\hline Diptera & Chironominae & Tanytarsus & 24 & 7 & CG/CF/PR & $\mathrm{BU} / \mathrm{CN} / \mathrm{SP}$ \\
\hline Diptera & Dasyheleinae & Dasyhelea & 8 & & CG & $\mathrm{BU} / \mathrm{SW}$ \\
\hline Diptera & Orthocladiinae & Cricotopus & 40 & & CG/SC & SP/BU \\
\hline Diptera & Orthocladiinae & Psectrocladius & 20 & & CG/SC & $\mathrm{SP} / \mathrm{BU}$ \\
\hline Diptera & Simuliidae & Simulium & 8 & 6 & CF & $\mathrm{CN}$ \\
\hline Diptera & Tanypodinae & Ablabesmyia & 4 & & PR & SP/BU \\
\hline Diptera & Tanypodinae & Procladius & 30 & & PR & SP/BU \\
\hline Ephemeropte & Caenis & Caenis latipennis & 104 & 8 & CG & "SP/75\%, CM/90\%" \\
\hline Ephemeropte & Caenis & Caenis youngi & 4 & 8 & CG & "SP/75\%, CM/90\%" \\
\hline Ephemeropte & Callibaetis & Callibaetis & 2 & 9 & CG & "SW/10\%, CN/90\%" \\
\hline Haplotaxida & Oligochaeta & Tubificidae & 12 & 8 & CG & $\mathrm{BU}$ \\
\hline Hemiptera & Corixidae & Corixidae & 20 & 9 & $\mathrm{PH} / \mathrm{PR}$ & SW \\
\hline Odonata & Coenagrionidae & Enallagma & 12 & 7 & PR & $\mathrm{CM}$ \\
\hline Odonata & Libellulidae & Sympetrum & 4 & 9 & PR & SP \\
\hline Trichoptera & Cheumatopsyche & Cheumatopsyche & 4 & 5 & CF & $\mathrm{CN}$ \\
\hline Trichoptera & Hydroptila & Hydroptila & 30 & 6 & $\mathrm{PH}$ & $\mathrm{CN}$ \\
\hline Trichoptera & Limnephilus & Limnephilus & 2 & 3 & $\mathrm{SH}$ & $\mathrm{CM} / \mathrm{SP}$ \\
\hline
\end{tabular}




\section{Montana Bioassessment Report}

Waterbody Name: Home Creek Site 1A for the Coal Tracts Study Station ID: OTTER_1At2

Reference Status:

Site Classification:

Latitude: Longitude:
Benthic Sample ID: 18130

Rep. Num 0

STORET Activity ID: $\quad$ OTTR1AM-MAC-R

Collection Date: 05/16/2013

Collection Method: MAC-R-500

Total Number of Individuals in Sample: $\quad 542$

\section{Sample Taxa List}

\begin{tabular}{|c|c|c|c|c|c|c|}
\hline \multirow[t]{2}{*}{ Order: } & OTU name: & $\begin{array}{l}\text { FinalID: } \\
\text { Ishnura }\end{array}$ & $\underset{4}{\text { Individuals }}$ & Tol Val: & $F F G$ : & Habit: \\
\hline & & Tropisternis & 24 & & & \\
\hline Amphipoda & Hyalella & Hyalella azteca & 220 & 8 & CG & SW/SP \\
\hline Basommatop & Lymnaeidae & Stagnicola caperata & 20 & 6 & CG & $\mathrm{CN}$ \\
\hline Basommatop & Physa_Physella & Physella acuta & 100 & 8 & CG & $\mathrm{CN}$ \\
\hline Basommatop & Physa_Physella & Physella gyrina & 6 & 8 & CG & $\mathrm{CN}$ \\
\hline Coleoptera & Coptotomus & Coptotomus longulus & 4 & 5 & PR & "CM (la), DI, SW (ad)" \\
\hline COLEOPTE & ILYBIUS & ILYBIUS & 4 & 5 & PR & \\
\hline Diptera & Ceratopogoninae & Bezzia & 4 & 6 & $\mathrm{PR} / \mathrm{CG}$ & SP/BU/SW \\
\hline Diptera & Chironominae & Chironomus & 16 & 7 & $\mathrm{CG} / \mathrm{CF} / \mathrm{PR}$ & $\mathrm{BU} / \mathrm{CN} / \mathrm{SP}$ \\
\hline Diptera & Chironominae & Glyptotendipes & 8 & 7 & $\mathrm{CG} / \mathrm{CF} / \mathrm{PR}$ & $\mathrm{BU} / \mathrm{CN} / \mathrm{SP}$ \\
\hline Diptera & Chironominae & Tanytarsus & 20 & 7 & $\mathrm{CG} / \mathrm{CF} / \mathrm{PR}$ & $\mathrm{BU} / \mathrm{CN} / \mathrm{SP}$ \\
\hline Diptera & Dasyheleinae & Dasyhelea & 4 & & CG & $\mathrm{BU} / \mathrm{SW}$ \\
\hline Diptera & Ephydridae & Ephydra & 8 & 6 & $C G$ & $\mathrm{BU}$ \\
\hline Diptera & Orthocladiinae & Corynoneura & 8 & & CG/SC & SP/BU \\
\hline Diptera & Orthocladiinae & Psectrocladius & 28 & & CG/SC & SP/BU \\
\hline Diptera & Sciomyzidae & Sepedon & 8 & & PR & $\mathrm{BU}$ \\
\hline Diptera & Tanypodinae & Procladius & 4 & & PR & SP/BU \\
\hline Haplotaxida & Oligochaeta & Tubificidae & 4 & 8 & CG & $\mathrm{BU}$ \\
\hline Hemiptera & Corixidae & Corixidae & 4 & 9 & $\mathrm{PH} / \mathrm{PR}$ & SW \\
\hline Non-Insect ta & Ostracoda & Ostracoda & 8 & & unk & SW \\
\hline Odonata & Aeshna & Aeshna palmata & 16 & & PR & $\mathrm{CM}$ \\
\hline Odonata & Amphiagrion & Amphiagrion abbreviatum & 4 & 7 & PR & $\mathrm{CM}$ \\
\hline Odonata & Coenagrionidae & Enallagma & 16 & 7 & PR & $\mathrm{CM}$ \\
\hline
\end{tabular}




\section{Montana Bioassessment Report}

Waterbody Name: Home Creek Site 1A for the Coal Tracts Study Station ID: OTTER_1At2f

Reference Status:

Site Classification:

Latitude:

Longitude:
Benthic Sample ID: 18131

Rep. Num 0

STORET Activity ID: OTR1AfM-MAC-R

Collection Date: 10/15/2013

Collection Method: MAC-R-500

Total Number of Individuals in Sample: 2150

\section{Sample Taxa List}

\begin{tabular}{|c|c|c|c|c|c|c|}
\hline Order: & OTU name: & FinalID: & Individuals & Tol Val: & FFG: & Habit: \\
\hline & & Proezzia & 11 & & & \\
\hline & & Tropisternis & 32 & & & \\
\hline Amphipoda & Hyalella & Hyalella azteca & 600 & 8 & CG & SW/SP \\
\hline Basommatop & Lymnaeidae & Stagnicola caperata & 32 & 6 & CG & $\mathrm{CN}$ \\
\hline Basommatop & Physa_Physella & Physella acuta & 188 & 8 & CG & $\mathrm{CN}$ \\
\hline Coleoptera & Berosus & Berosus & 4 & 5 & $\mathrm{PH}$ & "CM(la), DI,SW(ad)" \\
\hline Coleoptera & Coptotomus & Coptotomus longulus & 4 & 5 & PR & "CM (la), DI, SW (ad)" \\
\hline Coleoptera & Haliplus & Haliplus & 28 & 8 & $\mathrm{PH}$ & ;N,CM (la), SW,CM (ad \\
\hline Diptera & Ceratopogoninae & Bezzia & 8 & 6 & $\mathrm{PR} / \mathrm{CG}$ & SP/BU/SW \\
\hline Diptera & Ceratopogoninae & Culicoides & 16 & 6 & $\mathrm{PR} / \mathrm{CG}$ & SP/BU/SW \\
\hline Diptera & Ceratopogoninae & Probezzia & 4 & 6 & $\mathrm{PR} / \mathrm{CG}$ & SP/BU/SW \\
\hline Diptera & Chironominae & Chironomus & 184 & 7 & $\mathrm{CG} / \mathrm{CF} / \mathrm{PR}$ & $\mathrm{BU} / \mathrm{CN} / \mathrm{SP}$ \\
\hline Diptera & Chironominae & Glyptotendipes & 24 & 7 & $\mathrm{CG} / \mathrm{CF} / \mathrm{PR}$ & $\mathrm{BU} / \mathrm{CN} / \mathrm{SP}$ \\
\hline Diptera & Chironominae & Tanytarsus & 216 & 7 & $\mathrm{CG} / \mathrm{CF} / \mathrm{PR}$ & $\mathrm{BU} / \mathrm{CN} / \mathrm{SP}$ \\
\hline Diptera & Dasyheleinae & Dasyhelea & 24 & & CG & $\mathrm{BU} / \mathrm{SW}$ \\
\hline Diptera & Ephydridae & Ephydra & 8 & 6 & CG & $\mathrm{BU}$ \\
\hline Diptera & Orthocladiinae & Corynoneura & 24 & & CG/SC & SP/BU \\
\hline Diptera & Orthocladiinae & Psectrocladius & 473 & & CG/SC & SP/BU \\
\hline Diptera & Orthocladiinae & Thienemanniella & 8 & & CG/SC & SP/BU \\
\hline Diptera & Tanypodinae & Procladius & 22 & & PR & SP/BU \\
\hline Haplotaxida & Oligochaeta & Tubificidae & 16 & 8 & CG & $\mathrm{BU}$ \\
\hline Hemiptera & Corixidae & Corixidae & 112 & 9 & $\mathrm{PH} / \mathrm{PR}$ & SW \\
\hline Odonata & Aeshna & Aeshna palmata & 8 & & PR & $\mathrm{CM}$ \\
\hline Odonata & Coenagrionidae & Enallagma & 88 & 7 & PR & $\mathrm{CM}$ \\
\hline Odonata & Coenagrionidae & Ischnura & 12 & 7 & PR & $\mathrm{CM}$ \\
\hline
\end{tabular}




\section{Montana Bioassessment Report}

Waterbody Name: Home Creek Site 1A for the Coal Tracts Study Station ID: OTTER_1At2s

Reference Status:

Site Classification:

Latitude:

Longitude:
Benthic Sample ID: 18132

Rep. Num 0

STORET Activity ID: OTR1AsM-MAC-R

Collection Date: 07/16/2013

Collection Method: MAC-R-500

Total Number of Individuals in Sample: 2239

\section{Sample Taxa List}

\begin{tabular}{|c|c|c|c|c|c|c|}
\hline Order: & OTU name: & $\begin{array}{l}\text { FinalID: } \\
\text { Callibaetis fluctuans }\end{array}$ & $\begin{array}{c}\text { Individuals } \\
32\end{array}$ & Tol Val: & $F F G:$ & Habit: \\
\hline & & Tropisternis & 48 & & & \\
\hline Amphipoda & Hyalella & Hyalella azteca & 640 & 8 & $C G$ & SW/SP \\
\hline Basommatop & Lymnaeidae & Stagnicola caperata & 80 & 6 & CG & $\mathrm{CN}$ \\
\hline Basommatop & Physa_Physella & Physella acuta & 512 & 8 & CG & $\mathrm{CN}$ \\
\hline Coleoptera & Berosus & Berosus & 16 & 5 & $\mathrm{PH}$ & "CM(la), DI,SW(ad)" \\
\hline Coleoptera & Coptotomus & Coptotomus longulus & 16 & 5 & PR & "CM (la), DI, SW (ad)" \\
\hline Coleoptera & Haliplus & Haliplus & 128 & 8 & $\mathrm{PH}$ & ;N,CM (la), SW,CM (ad \\
\hline Coleoptera & Rhantus & Rhantus binotatus & 16 & & PR & "CM (la), DI, SW (ad)" \\
\hline Diptera & Ceratopogoninae & Bezzia & 16 & 6 & $\mathrm{PR} / \mathrm{CG}$ & SP/BU/SW \\
\hline Diptera & Ceratopogoninae & Culicoides & 32 & 6 & $\mathrm{PR} / \mathrm{CG}$ & $\mathrm{SP} / \mathrm{BU} / \mathrm{SW}$ \\
\hline Diptera & Chironominae & Chironomus & 224 & 7 & $\mathrm{CG} / \mathrm{CF} / \mathrm{PR}$ & $\mathrm{BU} / \mathrm{CN} / \mathrm{SP}$ \\
\hline Diptera & Chironominae & Glyptotendipes & 16 & 7 & $\mathrm{CG} / \mathrm{CF} / \mathrm{PR}$ & $\mathrm{BU} / \mathrm{CN} / \mathrm{SP}$ \\
\hline Diptera & Chironominae & Tanytarsus & 64 & 7 & $\mathrm{CG} / \mathrm{CF} / \mathrm{PR}$ & $\mathrm{BU} / \mathrm{CN} / \mathrm{SP}$ \\
\hline Diptera & Ephydridae & Ephydra & 32 & 6 & $C G$ & $\mathrm{BU}$ \\
\hline Diptera & Orthocladiinae & Corynoneura & 80 & & CG/SC & SP/BU \\
\hline Diptera & Orthocladiinae & Psectrocladius & 80 & & CG/SC & SP/BU \\
\hline Diptera & Sciomyzidae & Sciomyzidae & 16 & & PR & $\mathrm{BU}$ \\
\hline Diptera & Tanypodinae & Procladius & 64 & & PR & SP/BU \\
\hline Haplotaxida & Oligochaeta & Tubificidae & 16 & 8 & CG & $\mathrm{BU}$ \\
\hline Hemiptera & Corixidae & Corixidae & 96 & 9 & $\mathrm{PH} / \mathrm{PR}$ & SW \\
\hline Odonata & Aeshna & Aeshna palmata & 4 & & PR & $\mathrm{CM}$ \\
\hline Odonata & Coenagrionidae & Enallagma & 10 & 7 & PR & $\mathrm{CM}$ \\
\hline Odonata & Libellulidae & Sympetrum & 1 & 9 & PR & SP \\
\hline
\end{tabular}




\section{Montana Bioassessment Report}

Waterbody Name: Otter Creek Site 22 for the Coal Tracts Study Station ID: OTTER_22t2

Reference Status:

Site Classification:

Latitude: Longitude:
Benthic Sample ID: 18133

Rep. Num 0

STORET Activity ID: $\quad$ OTTR22M-MAC-R

Collection Date: $\quad$ 05/17/2013

Collection Method: MAC-R-500

Total Number of Individuals in Sample: 2064

\section{Sample Taxa List}

\begin{tabular}{|c|c|c|c|c|c|c|}
\hline Order: & OTU name: & FinalID: & Individuals & Tol Val: & $F F G:$ & Habit: \\
\hline Amphipoda & Hyalella & Hyalella azteca & 144 & 8 & CG & SW/SP \\
\hline Basommatop & Physa_Physella & Physella acuta & 320 & 8 & CG & $\mathrm{CN}$ \\
\hline Basommatop & Planorbidae & Gyraulus parvus & 160 & 6 & CG & $\mathrm{CN}$ \\
\hline Coleoptera & Dubiraphia & Dubiraphia vittata & 16 & 6 & SC/CG & "CN/50\%, BU/50\%" \\
\hline Diptera & Ceratopogoninae & Bezzia & 16 & 6 & $\mathrm{PR} / \mathrm{CG}$ & $\mathrm{SP} / \mathrm{BU} / \mathrm{SW}$ \\
\hline Diptera & Ceratopogoninae & Probezzia & 32 & 6 & $\mathrm{PR} / \mathrm{CG}$ & $\mathrm{SP} / \mathrm{BU} / \mathrm{SW}$ \\
\hline Diptera & Chironominae & Chironomus & 48 & 7 & $\mathrm{CG} / \mathrm{CF} / \mathrm{PR}$ & $\mathrm{BU} / \mathrm{CN} / \mathrm{SP}$ \\
\hline Diptera & Chironominae & Cryptochironomus & 32 & 7 & $\mathrm{CG} / \mathrm{CF} / \mathrm{PR}$ & $\mathrm{BU} / \mathrm{CN} / \mathrm{SP}$ \\
\hline Diptera & Chironominae & Dicrotendipes & 16 & 7 & $\mathrm{CG} / \mathrm{CF} / \mathrm{PR}$ & $\mathrm{BU} / \mathrm{CN} / \mathrm{SP}$ \\
\hline Diptera & Chironominae & Glyptotendipes & 80 & 7 & $\mathrm{CG} / \mathrm{CF} / \mathrm{PR}$ & $\mathrm{BU} / \mathrm{CN} / \mathrm{SP}$ \\
\hline Diptera & Chironominae & Microtendipes pedellus Gr. & 320 & 7 & $\mathrm{CG} / \mathrm{CF} / \mathrm{PR}$ & $\mathrm{BU} / \mathrm{CN} / \mathrm{SP}$ \\
\hline Diptera & Chironominae & Polypedilum & 16 & 7 & $\mathrm{CG} / \mathrm{CF} / \mathrm{PR}$ & $\mathrm{BU} / \mathrm{CN} / \mathrm{SP}$ \\
\hline Diptera & Chironominae & Tanytarsus & 112 & 7 & $\mathrm{CG} / \mathrm{CF} / \mathrm{PR}$ & $\mathrm{BU} / \mathrm{CN} / \mathrm{SP}$ \\
\hline Diptera & Orthocladiinae & Psectrocladius & 112 & & $\mathrm{CG} / \mathrm{SC}$ & SP/BU \\
\hline Diptera & Simuliidae & Simulium & 64 & 6 & $\mathrm{CF}$ & $\mathrm{CN}$ \\
\hline Diptera & Tanypodinae & Procladius & 192 & & PR & SP/BU \\
\hline Ephemeropte & Caenis & Caenis latipennis & 64 & 8 & CG & "SP/75\%, CM/90\%" \\
\hline Haplotaxida & Oligochaeta & Tubificidae & 80 & 8 & CG & $\mathrm{BU}$ \\
\hline Hemiptera & Corixidae & Corixidae & 32 & 9 & $\mathrm{PH} / \mathrm{PR}$ & SW \\
\hline Non-Insect ta & Ostracoda & Ostracoda & 128 & & unk & SW \\
\hline Odonata & Coenagrionidae & Enallagma & 32 & 7 & PR & $\mathrm{CM}$ \\
\hline Odonata & Coenagrionidae & Ischnura & 16 & 7 & PR & $\mathrm{CM}$ \\
\hline Odonata & Libellulidae & Libellula pulchella & 16 & 9 & PR & SP \\
\hline Trichoptera & Limnephilus & Limnephilus & 16 & 3 & $\mathrm{SH}$ & $\mathrm{CM} / \mathrm{SP}$ \\
\hline
\end{tabular}




\section{Montana Bioassessment Report}

Waterbody Name: Otter Creek Site 22 for the Coal Tracts Study Station ID: OTTER_22t2s

Reference Status:

Site Classification:

Latitude: Longitude:
Benthic Sample ID: 18134

Rep. Num 0

STORET Activity ID: $\quad$ OTR22sM-MAC-R

Collection Date: $\quad$ 07/16/2013

Collection Method: MAC-R-500

Total Number of Individuals in Sample: $\quad 899$

\section{Sample Taxa List}

\begin{tabular}{|c|c|c|c|c|c|c|}
\hline Order: & OTU name: & $\begin{array}{l}\text { FinalID: } \\
\text { Helisoma trivolvis }\end{array}$ & ndividuals & Tol Val: & $F F G:$ & Habit: \\
\hline Amphipoda & Hyalella & Hyalella & 107 & 8 & CG & SW/SP \\
\hline Basommatop & Lymnaeidae & Pseudosuccinea columella & 1 & 6 & CG & $\mathrm{CN}$ \\
\hline Basommatop & Physa_Physella & Physella acuta & 212 & 8 & CG & $\mathrm{CN}$ \\
\hline Basommatop & Planorbidae & Gyraulus parvus & 13 & 6 & CG & $\mathrm{CN}$ \\
\hline BASOMMAT & Planorbidae & HELISOMA ANCEPS & 3 & 6 & CG & $\mathrm{CN}$ \\
\hline Coleoptera & Berosus & Berosus & 2 & 5 & $\mathrm{PH}$ & "CM(la), DI,SW(ad)" \\
\hline Coleoptera & Colymbetes & Colymbetes & 1 & & PR & "CM(la), DI,SW(ad)" \\
\hline Coleoptera & Haliplus & Haliplus & 15 & 8 & $\mathrm{PH}$ & ;N,CM (la), SW,CM (ad \\
\hline Coleoptera & Hydroporus & Hydroporus & 7 & & PR & "CM (la), DI, SW (ad)" \\
\hline Coleoptera & Peltodytes & Peltodytes & 3 & 8 & $\mathrm{PH}$ & ;N,CM (la), SW,CM (ad \\
\hline Diptera & Chironominae & Chironomus & 2 & 7 & $\mathrm{CG} / \mathrm{CF} / \mathrm{PR}$ & $\mathrm{BU} / \mathrm{CN} / \mathrm{SP}$ \\
\hline Diptera & Chironominae & Dicrotendipes & 5 & 7 & $\mathrm{CG} / \mathrm{CF} / \mathrm{PR}$ & $\mathrm{BU} / \mathrm{CN} / \mathrm{SP}$ \\
\hline Diptera & Chironominae & Glyptotendipes & 23 & 7 & $\mathrm{CG} / \mathrm{CF} / \mathrm{PR}$ & $\mathrm{BU} / \mathrm{CN} / \mathrm{SP}$ \\
\hline Diptera & Chironominae & Microtendipes pedellus $\mathrm{Gr}$. & 2 & 7 & $\mathrm{CG} / \mathrm{CF} / \mathrm{PR}$ & $\mathrm{BU} / \mathrm{CN} / \mathrm{SP}$ \\
\hline Diptera & Chironominae & Tanytarsus & 40 & 7 & $\mathrm{CG} / \mathrm{CF} / \mathrm{PR}$ & $\mathrm{BU} / \mathrm{CN} / \mathrm{SP}$ \\
\hline Diptera & Dixella & Dixella & 1 & & CG & SW \\
\hline Diptera & Orthocladiinae & Cricotopus & 7 & & CG/SC & SP/BU \\
\hline Diptera & Orthocladiinae & Psectrocladius & 22 & & CG/SC & SP/BU \\
\hline Diptera & Simuliidae & Simulium & 4 & 6 & $\mathrm{CF}$ & $\mathrm{CN}$ \\
\hline Diptera & Tanypodinae & Ablabesmyia & 20 & & PR & SP/BU \\
\hline Diptera & Tanypodinae & Procladius & 17 & & PR & SP/BU \\
\hline Diptera & Tanypodinae & Thienemannimyia Gr. & 6 & & PR & SP/BU \\
\hline Ephemeropte & Caenis & Caenis latipennis & 259 & 8 & CG & "SP/75\%, CM/90\%" \\
\hline Ephemeropte & Caenis & Caenis youngi & 4 & 8 & CG & "SP/75\%, CM/90\%" \\
\hline Ephemeropte & Callibaetis & Callibaetis & 36 & 9 & CG & "SW/10\%, CN/90\%" \\
\hline Haplotaxida & Oligochaeta & Tubificidae & 5 & 8 & CG & $\mathrm{BU}$ \\
\hline Hemiptera & Corixidae & Corixidae & 5 & 9 & $\mathrm{PH} / \mathrm{PR}$ & SW \\
\hline Non-Insect ta & Ostracoda & Ostracoda & 22 & & unk & SW \\
\hline Odonata & Aeshna & Aeshna palmata & 6 & & PR & $\mathrm{CM}$ \\
\hline Odonata & Coenagrionidae & Enallagma & 35 & 7 & PR & $\mathrm{CM}$ \\
\hline Odonata & Lestes & Lestes & 6 & 9 & PR & SW \\
\hline Rhynchobdell & Glossiphoniidae & Glossiphonia complanata & 2 & 9 & PR & SW \\
\hline Rhynchobdell & Glossiphoniidae & Helobdella stagnalis & 2 & 9 & PR & SW \\
\hline Trichoptera & Limnephilus & Limnephilus & 3 & 3 & $\mathrm{SH}$ & $\mathrm{CM} / \mathrm{SP}$ \\
\hline
\end{tabular}




\section{Montana Bioassessment Report}

Waterbody Name: Tenmile Creek Site 23 for the Coal Tracts Study Benthic Sample ID: 18135

Station ID: Otter_23t2f

Rep. Num 0

Reference Status:

STORET Activity ID: $\quad$ OTR23fM-MAC-R

Site Classification:

Collection Date: 10/15/2011

Latitude:

Collection Method: MAC-R-500

Longitude:

Total Number of Individuals in Sample: $\quad 484$

\section{Sample Taxa List}

\begin{tabular}{|lllcccc|}
\hline Order: & OTU name: & FinalID: & Individuals & Tol Val: & FFG: & Habit: \\
Coleoptera & Agabus & Agabus & 25 & 5 & PR & "CM(la), DI,SW(ad)" \\
Coleoptera & Colymbetes & Colymbetes & 5 & & PR & "CM(la), DI,SW(ad)" \\
Coleoptera & Coptotomus & Coptotomus longulus & 6 & 5 & PR & "CM (la), DI, SW (ad)" \\
Coleoptera & Rhantus & Rhantus & 10 & & PR & "CM (la), DI, SW (ad)" \\
Diptera & Chironominae & Chironomus & 30 & 7 & CG/CF/PR & BU/CN/SP \\
Diptera & Chironominae & Tanytarsus & 177 & 7 & CG/CF/PR & BU/CN/SP \\
Diptera & Ephydridae & Ephydridae & 13 & 6 & CG & BU \\
Diptera & Orthocladiinae & Psectrocladius & 145 & & CG/SC & SP/BU \\
Hemiptera & Corixidae & Corixidae & 22 & 9 & PH/PR & SW \\
Hemiptera & Corixidae & Sigara & 18 & 9 & PH/PR & SW \\
Non-Insect ta & Ostracoda & Ostracoda & 33 & & unk & SW
\end{tabular}




\section{Montana Bioassessment Report}

Waterbody Name: Otter Creek Site 22 for the Coal Tracts Study Station ID: OTTER_2t2f

Reference Status:

Site Classification:

Latitude: Longitude:
Benthic Sample ID: 18136

Rep. Num 0

STORET Activity ID: $\quad$ OTR22fM-MAC-R

Collection Date: $\quad$ 10/14/2013

Collection Method: MAC-R-500

Total Number of Individuals in Sample: 1992

\section{Sample Taxa List}

\begin{tabular}{|c|c|c|c|c|c|c|}
\hline Order: & OTU name: & $\begin{array}{l}\text { FinalID: } \\
\text { Callibaetis fluctuans }\end{array}$ & $\begin{array}{c}\text { Individuals } \\
24\end{array}$ & Tol Val: & $F F G$ & Habit: \\
\hline & & Gyraulus circumstriatus & 24 & & & \\
\hline & & Helisoma trivolvis & 8 & & & \\
\hline Amphipoda & Hyalella & Hyalella azteca & 660 & 8 & CG & SW/SP \\
\hline Basommatop & Physa_Physella & Physella acuta & 336 & 8 & CG & $\mathrm{CN}$ \\
\hline Basommatop & Planorbidae & Gyraulus parvus & 88 & 6 & $\mathrm{CG}$ & $\mathrm{CN}$ \\
\hline Coleoptera & Berosus & Berosus & 8 & 5 & $\mathrm{PH}$ & "CM(la), DI,SW(ad)" \\
\hline Coleoptera & Coptotomus & Coptotomus longulus & 4 & 5 & PR & "CM (la), DI, SW (ad)" \\
\hline Coleoptera & Dubiraphia & Dubiraphia vittata & 60 & 6 & SC/CG & "CN/50\%, BU/50\%" \\
\hline Coleoptera & Haliplus & Haliplus & 8 & 8 & $\mathrm{PH}$ & ;N,CM (la), SW,CM (ad \\
\hline Coleoptera & Peltodytes & Peltodytes & 4 & 8 & $\mathrm{PH}$ & ;N,CM (la), SW,CM (ad \\
\hline Diptera & Chironominae & Chironomus & 12 & 7 & CG/CF/PR & $\mathrm{BU} / \mathrm{CN} / \mathrm{SP}$ \\
\hline Diptera & Chironominae & Cryptochironomus & 16 & 7 & CG/CF/PR & $\mathrm{BU} / \mathrm{CN} / \mathrm{SP}$ \\
\hline Diptera & Chironominae & Dicrotendipes & 32 & 7 & CG/CF/PR & $\mathrm{BU} / \mathrm{CN} / \mathrm{SP}$ \\
\hline Diptera & Chironominae & Paratanytarsus & 16 & 7 & $\mathrm{CG} / \mathrm{CF} / \mathrm{PR}$ & $\mathrm{BU} / \mathrm{CN} / \mathrm{SP}$ \\
\hline Diptera & Chironominae & Polypedilum & 20 & 7 & CG/CF/PR & $\mathrm{BU} / \mathrm{CN} / \mathrm{SP}$ \\
\hline Diptera & Chironominae & Pseudochironomus & 8 & 7 & CG/CF/PR & $\mathrm{BU} / \mathrm{CN} / \mathrm{SP}$ \\
\hline Diptera & Chironominae & Tanytarsus & 72 & 7 & CG/CF/PR & $\mathrm{BU} / \mathrm{CN} / \mathrm{SP}$ \\
\hline Diptera & Dolichopodidae & Dolichopodidae & 4 & 4 & PR & SP \\
\hline Diptera & Hemerodromia & Hemerodromia & 4 & 6 & PR & SP \\
\hline Diptera & Orthocladiinae & Psectrocladius & 20 & & CG/SC & SP/BU \\
\hline Diptera & Tabanidae & Chrysops & 8 & 10 & PR & SP \\
\hline Diptera & Tanypodinae & Procladius & 76 & & PR & SP/BU \\
\hline Diptera & Tanypodinae & Radotanypus & 8 & & PR & SP/BU \\
\hline Ephemeropte & Caenis & Caenis latipennis & 176 & 8 & CG & "SP/75\%, CM/90\%" \\
\hline Ephemeropte & Caenis & Caenis youngi & 8 & 8 & CG & "SP/75\%, CM/90\%" \\
\hline Haplotaxida & Oligochaeta & Tubificidae & 8 & 8 & CG & $\mathrm{BU}$ \\
\hline Hemiptera & Corixidae & Corixidae & 140 & 9 & $\mathrm{PH} / \mathrm{PR}$ & SW \\
\hline Non-Insect ta & Ostracoda & Ostracoda & 28 & & unk & SW \\
\hline Odonata & Aeshna & Aeshna palmata & 32 & & PR & $\mathrm{CM}$ \\
\hline Odonata & Coenagrionidae & Enallagma & 48 & 7 & PR & $\mathrm{CM}$ \\
\hline Odonata & Libellulidae & Libellula forensis & 8 & 9 & PR & SP \\
\hline Odonata & Libellulidae & Libellula pulchella & 12 & 9 & PR & SP \\
\hline Odonata & Libellulidae & Sympetrum & 4 & 9 & PR & SP \\
\hline Trichoptera & Limnephilus & Limnephilus & 8 & 3 & $\mathrm{SH}$ & $\mathrm{CM} / \mathrm{SP}$ \\
\hline
\end{tabular}




\section{Montana Bioassessment Report}

Waterbody Name: Otter Creek Site ASJT for the Coal Tracts Study Station ID: OTTER_JTt2

Reference Status:

Site Classification:

Latitude: Longitude:
Benthic Sample ID: 18137

Rep. Num 0

STORET Activity ID: OTTRJTM-MAC-R

Collection Date: $\quad$ 05/17/2013

Collection Method: MAC-R-500

Total Number of Individuals in Sample: $\quad 750$

\section{Sample Taxa List}

\begin{tabular}{|c|c|c|c|c|c|c|}
\hline Order: & OTU name: & $\begin{array}{ll}\text { FinalID: } & \text { In } \\
\text { Arigomphus cornutus } & \end{array}$ & ndividuals & Tol Val: & $F F G:$ & Habit: \\
\hline Amphipoda & Hyalella & Hyalella & 80 & 8 & CG & SW/SP \\
\hline Basommatop & Physa_Physella & Physella acuta & 40 & 8 & CG & $\mathrm{CN}$ \\
\hline Basommatop & Planorbidae & Gyraulus parvus & 20 & 6 & CG & $\mathrm{CN}$ \\
\hline Coleoptera & Agabus & Agabus & 4 & 5 & PR & "CM(la), DI,SW(ad)" \\
\hline Coleoptera & Dubiraphia & Dubiraphia vittata & 88 & 6 & $\mathrm{SC} / \mathrm{CG}$ & "CN/50\%, BU/50\%" \\
\hline Diptera & Ceratopogoninae & Bezzia & 8 & 6 & $\mathrm{PR} / \mathrm{CG}$ & SP/BU/SW \\
\hline Diptera & Chironominae & Chironomus & 112 & 7 & $\mathrm{CG} / \mathrm{CF} / \mathrm{PR}$ & $\mathrm{BU} / \mathrm{CN} / \mathrm{SP}$ \\
\hline Diptera & Chironominae & Cladotanytarsus & 4 & 7 & $\mathrm{CG} / \mathrm{CF} / \mathrm{PR}$ & $\mathrm{BU} / \mathrm{CN} / \mathrm{SP}$ \\
\hline Diptera & Chironominae & Cryptochironomus & 24 & 7 & $\mathrm{CG} / \mathrm{CF} / \mathrm{PR}$ & $\mathrm{BU} / \mathrm{CN} / \mathrm{SP}$ \\
\hline Diptera & Chironominae & Dicrotendipes & 32 & 7 & CG/CF/PR & $\mathrm{BU} / \mathrm{CN} / \mathrm{SP}$ \\
\hline Diptera & Chironominae & Glyptotendipes & 52 & 7 & $\mathrm{CG} / \mathrm{CF} / \mathrm{PR}$ & $\mathrm{BU} / \mathrm{CN} / \mathrm{SP}$ \\
\hline Diptera & Chironominae & Microtendipes pedellus Gr. & 20 & 7 & $\mathrm{CG} / \mathrm{CF} / \mathrm{PR}$ & $\mathrm{BU} / \mathrm{CN} / \mathrm{SP}$ \\
\hline Diptera & Chironominae & Polypedilum & 4 & 7 & $\mathrm{CG} / \mathrm{CF} / \mathrm{PR}$ & $\mathrm{BU} / \mathrm{CN} / \mathrm{SP}$ \\
\hline Diptera & Chironominae & Tanytarsus & 28 & 7 & $\mathrm{CG} / \mathrm{CF} / \mathrm{PR}$ & $\mathrm{BU} / \mathrm{CN} / \mathrm{SP}$ \\
\hline Diptera & Ephydridae & Ephydra & 4 & 6 & CG & $\mathrm{BU}$ \\
\hline Diptera & Orthocladiinae & Cricotopus & 10 & & CG/SC & SP/BU \\
\hline Diptera & Orthocladiinae & Psectrocladius & 24 & & CG/SC & SP/BU \\
\hline Diptera & Simuliidae & Simulium & 68 & 6 & CF & $\mathrm{CN}$ \\
\hline Diptera & Tanypodinae & Ablabesmyia & 8 & & PR & SP/BU \\
\hline Diptera & Tanypodinae & Procladius & 8 & & PR & SP/BU \\
\hline Diptera & Tanypodinae & Thienemannimyia Gr. & 4 & & PR & SP/BU \\
\hline Ephemeropte & Caenis & Caenis latipennis & 4 & 8 & CG & "SP/75\%, CM/90\%" \\
\hline Ephemeropte & Callibaetis & Callibaetis & 4 & 9 & CG & "SW/10\%, CN/90\%" \\
\hline Haplotaxida & Oligochaeta & Tubificidae & 36 & 8 & CG & $\mathrm{BU}$ \\
\hline Hemiptera & Corixidae & Corixidae & 12 & 9 & $\mathrm{PH} / \mathrm{PR}$ & SW \\
\hline Non-Insect ta & Ostracoda & Ostracoda & 12 & & unk & SW \\
\hline Odonata & Aeshna & Aeshna palmata & 4 & & PR & $\mathrm{CM}$ \\
\hline Odonata & Coenagrionidae & Enallagma & 8 & 7 & PR & $\mathrm{CM}$ \\
\hline Trichoptera & Cheumatopsyche & Cheumatopsyche & 16 & 5 & CF & $\mathrm{CN}$ \\
\hline Trichoptera & Hydroptila & Hydroptila & 4 & 6 & $\mathrm{PH}$ & $\mathrm{CN}$ \\
\hline Trichoptera & Limnephilus & Limnephilus & 4 & 3 & $\mathrm{SH}$ & $\mathrm{CM} / \mathrm{SP}$ \\
\hline
\end{tabular}




\section{Montana Bioassessment Report}

Waterbody Name: Otter Creek Site ASJT for the Coal Tracts Study Station ID: OTTER_JTt2f

Reference Status:

Site Classification:

Latitude: Longitude:
Benthic Sample ID: 18138

Rep. Num 0

STORET Activity ID: OTRJTfM-MAC-R

Collection Date: $\quad$ 10/15/2013

Collection Method: MAC-R-500

Total Number of Individuals in Sample: 2012

\section{Sample Taxa List}

\begin{tabular}{|c|c|c|c|c|c|c|}
\hline \multirow[t]{3}{*}{ Order: } & OTU name: & $\begin{array}{l}\text { FinalID: } \\
\text { callibaetus }\end{array}$ & $\begin{array}{c}16 \\
16\end{array}$ & Tol Val: & $F F G$ & Habit: \\
\hline & & Gyraulus circumstriatus & 12 & & & \\
\hline & & Pisidium castertanium & 8 & & & \\
\hline Amphipoda & Hyalella & Hyalella azteca & 60 & 8 & CG & SW/SP \\
\hline Basommatop & Physa_Physella & Physella acuta & 80 & 8 & CG & $\mathrm{CN}$ \\
\hline Basommatop & Planorbidae & Gyraulus parvus & 36 & 6 & CG & $\mathrm{CN}$ \\
\hline BASOMMAT & Planorbidae & HELISOMA ANCEPS & 4 & 6 & CG & $\mathrm{CN}$ \\
\hline Coleoptera & Berosus & Berosus & 4 & 5 & $\mathrm{PH}$ & "CM(la), DI,SW(ad)" \\
\hline COLEOPTE & DINEUTUS & DINEUTUS & 4 & 4 & PR & \\
\hline Coleoptera & Dubiraphia & Dubiraphia vittata & 192 & 6 & $\mathrm{SC} / \mathrm{CG}$ & "CN/50\%, BU/50\%" \\
\hline Coleoptera & Haliplus & Haliplus & 8 & 8 & $\mathrm{PH}$ & ;N,CM (la), SW,CM (ad \\
\hline Diptera & Ceratopogoninae & Bezzia & 4 & 6 & $\mathrm{PR} / \mathrm{CG}$ & SP/BU/SW \\
\hline Diptera & Ceratopogoninae & Culicoides & 4 & 6 & $\mathrm{PR} / \mathrm{CG}$ & $\mathrm{SP} / \mathrm{BU} / \mathrm{SW}$ \\
\hline Diptera & Ceratopogoninae & Probezzia & 8 & 6 & $\mathrm{PR} / \mathrm{CG}$ & $\mathrm{SP} / \mathrm{BU} / \mathrm{SW}$ \\
\hline Diptera & Chironominae & Chironomus & 184 & 7 & $\mathrm{CG} / \mathrm{CF} / \mathrm{PR}$ & $\mathrm{BU} / \mathrm{CN} / \mathrm{SP}$ \\
\hline Diptera & Chironominae & Cryptochironomus & 20 & 7 & $\mathrm{CG} / \mathrm{CF} / \mathrm{PR}$ & $\mathrm{BU} / \mathrm{CN} / \mathrm{SP}$ \\
\hline Diptera & Chironominae & Dicrotendipes & 24 & 7 & $\mathrm{CG} / \mathrm{CF} / \mathrm{PR}$ & $\mathrm{BU} / \mathrm{CN} / \mathrm{SP}$ \\
\hline Diptera & Chironominae & Glyptotendipes & 152 & 7 & $\mathrm{CG} / \mathrm{CF} / \mathrm{PR}$ & $\mathrm{BU} / \mathrm{CN} / \mathrm{SP}$ \\
\hline Diptera & Chironominae & Microtendipes pedellus Gr. & 8 & 7 & CG/CF/PR & $\mathrm{BU} / \mathrm{CN} / \mathrm{SP}$ \\
\hline Diptera & Chironominae & Polypedilum & 16 & 7 & $\mathrm{CG} / \mathrm{CF} / \mathrm{PR}$ & $\mathrm{BU} / \mathrm{CN} / \mathrm{SP}$ \\
\hline Diptera & Chironominae & Tanytarsus & 104 & 7 & $\mathrm{CG} / \mathrm{CF} / \mathrm{PR}$ & $\mathrm{BU} / \mathrm{CN} / \mathrm{SP}$ \\
\hline Diptera & Dasyheleinae & Dasyhelea & 4 & & CG & $\mathrm{BU} / \mathrm{SW}$ \\
\hline Diptera & Orthocladiinae & Cricotopus & 132 & & CG/SC & SP/BU \\
\hline Diptera & Orthocladiinae & Cricotopus bicinctus & 32 & & CG/SC & SP/BU \\
\hline Diptera & Orthocladiinae & Psectrocladius & 100 & & CG/SC & SP/BU \\
\hline Diptera & Simuliidae & Simulium & 80 & 6 & $\mathrm{CF}$ & $\mathrm{CN}$ \\
\hline Diptera & Tanypodinae & Ablabesmyia & 8 & & PR & $\mathrm{SP} / \mathrm{BU}$ \\
\hline Diptera & Tanypodinae & Procladius & 56 & & PR & SP/BU \\
\hline Diptera & Tanypodinae & Radotanypus & 8 & & PR & SP/BU \\
\hline Ephemeropte & Caenis & Caenis latipennis & 208 & 8 & CG & "SP/75\%, CM/90\%" \\
\hline Haplotaxida & Oligochaeta & Tubificidae & 48 & 8 & CG & $\mathrm{BU}$ \\
\hline Hemiptera & Corixidae & Corixidae & 312 & 9 & $\mathrm{PH} / \mathrm{PR}$ & SW \\
\hline Megaloptera & Sialidae & Sialis velata & 36 & 4 & unk & "CN,CM,BU" \\
\hline Odonata & Coenagrionidae & Enallagma & 16 & 7 & PR & $\mathrm{CM}$ \\
\hline Trichoptera & Hydroptila & Hydroptila & 8 & 6 & $\mathrm{PH}$ & $\mathrm{CN}$ \\
\hline
\end{tabular}




\section{Montana Bioassessment Report}

Waterbody Name: Otter Creek Site ASJT for the Coal Tracts Study Benthic Sample ID: 18138 Station ID: OTTER_JTt2f

Rep. Num 0

Reference Status:

STORET Activity ID: OTRJTfM-MAC-R

Site Classification:

Collection Date: 10/15/2013

Latitude:

Collection Method: MAC-R-500

Longitude:

Total Number of Individuals in Sample: 2012

\begin{tabular}{|cl}
\hline Trichoptera & Limnephilus \\
Trichoptera & Polycentropus
\end{tabular}

Limnephilus

3

Polycentropus

8

6

$\mathrm{SH}$

CM/SP

PR CN




\section{Montana Bioassessment Report}

Waterbody Name: Otter Creek Site ASJT for the Coal Tracts Study Station ID: OTTER_JTt2s

Reference Status:

Site Classification:

Latitude: Longitude:
Benthic Sample ID: 18139

Rep. Num 0

STORET Activity ID: OTRJTSM-MAC-R

Collection Date: $\quad$ 07/17/2013

Collection Method: MAC-R-500

Total Number of Individuals in Sample: 2012

\section{Sample Taxa List}

\begin{tabular}{|c|c|c|c|c|c|c|}
\hline \multirow[t]{3}{*}{ Order: } & \multirow[t]{3}{*}{ OTU name: } & FinalID: & \multirow{2}{*}{$\begin{array}{c}\text { Individuals } \\
8\end{array}$} & \multirow[t]{3}{*}{ Tol Val: } & \multirow[t]{3}{*}{$F F G:$} & \multirow[t]{3}{*}{ Habit: } \\
\hline & & Gyraulus circumstriatus & & & & \\
\hline & & Pisidium castertanium & 4 & & & \\
\hline Amphipoda & Hyalella & Hyalella azteca & 84 & 8 & CG & SW/SP \\
\hline Basommatop & Physa_Physella & Physella acuta & 88 & 8 & CG & $\mathrm{CN}$ \\
\hline Basommatop & Planorbidae & Gyraulus parvus & 8 & 6 & CG & $\mathrm{CN}$ \\
\hline Coleoptera & Berosus & Berosus & 4 & 5 & $\mathrm{PH}$ & "CM(la), DI,SW(ad)" \\
\hline Coleoptera & Dubiraphia & Dubiraphia vittata & 76 & 6 & $\mathrm{SC} / \mathrm{CG}$ & "CN/50\%, BU/50\%" \\
\hline Coleoptera & Haliplus & Haliplus & 4 & 8 & $\mathrm{PH}$ & ;N,CM (la), SW,CM (ad \\
\hline Coleoptera & Microcylloepus & Microcylloepus pusillus & 8 & 5 & CG & "CN/50\%, BU/50\%" \\
\hline Diptera & Ceratopogoninae & Bezzia & 20 & 6 & $\mathrm{PR} / \mathrm{CG}$ & SP/BU/SW \\
\hline Diptera & Ceratopogoninae & Culicoides & 4 & 6 & $\mathrm{PR} / \mathrm{CG}$ & SP/BU/SW \\
\hline Diptera & Ceratopogoninae & Probezzia & 8 & 6 & $\mathrm{PR} / \mathrm{CG}$ & SP/BU/SW \\
\hline Diptera & Chironominae & Chironomus & 360 & 7 & $\mathrm{CG} / \mathrm{CF} / \mathrm{PR}$ & $\mathrm{BU} / \mathrm{CN} / \mathrm{SP}$ \\
\hline Diptera & Chironominae & Cryptochironomus & 68 & 7 & $\mathrm{CG} / \mathrm{CF} / \mathrm{PR}$ & $\mathrm{BU} / \mathrm{CN} / \mathrm{SP}$ \\
\hline Diptera & Chironominae & Dicrotendipes & 88 & 7 & $\mathrm{CG} / \mathrm{CF} / \mathrm{PR}$ & $\mathrm{BU} / \mathrm{CN} / \mathrm{SP}$ \\
\hline Diptera & Chironominae & Glyptotendipes & 152 & 7 & $\mathrm{CG} / \mathrm{CF} / \mathrm{PR}$ & $\mathrm{BU} / \mathrm{CN} / \mathrm{SP}$ \\
\hline Diptera & Chironominae & Microtendipes pedellus Gr. & 8 & 7 & $\mathrm{CG} / \mathrm{CF} / \mathrm{PR}$ & $\mathrm{BU} / \mathrm{CN} / \mathrm{SP}$ \\
\hline Diptera & Chironominae & Polypedilum & 60 & 7 & $\mathrm{CG} / \mathrm{CF} / \mathrm{PR}$ & $\mathrm{BU} / \mathrm{CN} / \mathrm{SP}$ \\
\hline Diptera & Chironominae & Pseudochironomus & 4 & 7 & $\mathrm{CG} / \mathrm{CF} / \mathrm{PR}$ & $\mathrm{BU} / \mathrm{CN} / \mathrm{SP}$ \\
\hline Diptera & Chironominae & Tanytarsus & 48 & 7 & $\mathrm{CG} / \mathrm{CF} / \mathrm{PR}$ & $\mathrm{BU} / \mathrm{CN} / \mathrm{SP}$ \\
\hline Diptera & Dasyheleinae & Dasyhelea & 4 & & CG & $\mathrm{BU} / \mathrm{SW}$ \\
\hline Diptera & Orthocladiinae & Cricotopus & 20 & & CG/SC & SP/BU \\
\hline Diptera & Orthocladiinae & Cricotopus bicinctus & 40 & & CG/SC & SP/BU \\
\hline Diptera & Orthocladiinae & Psectrocladius & 20 & & CG/SC & SP/BU \\
\hline Diptera & Simuliidae & Simulium & 16 & 6 & CF & $\mathrm{CN}$ \\
\hline Diptera & Tanypodinae & Procladius & 84 & & PR & SP/BU \\
\hline Diptera & Tanypodinae & Thienemannimyia Gr. & 20 & & PR & SP/BU \\
\hline Ephemeropte & Caenis & Caenis latipennis & 80 & 8 & CG & "SP/75\%, CM/90\%" \\
\hline Ephemeropte & Callibaetis & Callibaetis & 20 & 9 & CG & "SW/10\%, CN/90\%" \\
\hline Haplotaxida & Oligochaeta & Tubificidae & 32 & 8 & CG & $\mathrm{BU}$ \\
\hline Hemiptera & Corixidae & Corixidae & 528 & 9 & $\mathrm{PH} / \mathrm{PR}$ & SW \\
\hline Heterostroph & Valvata & Valvata humeralis & 4 & 3 & SC & $\mathrm{CM}$ \\
\hline Odonata & Coenagrionidae & Enallagma & 16 & 7 & PR & $\mathrm{CM}$ \\
\hline Trichoptera & Hydroptila & Hydroptila & 20 & 6 & $\mathrm{PH}$ & $\mathrm{CN}$ \\
\hline Trichoptera & Limnephilus & Limnephilus & 4 & 3 & $\mathrm{SH}$ & $\mathrm{CM} / \mathrm{SP}$ \\
\hline
\end{tabular}


Appendix C. Stream Habitat and Water Quality Parameters measured for the Otter Creek sites visited in 2013. na = not visited or sampled during this visit, dry.

\begin{tabular}{|c|c|c|c|c|c|c|c|c|c|c|c|c|c|c|c|c|c|c|c|c|c|}
\hline \multirow[t]{2}{*}{2013} & \multicolumn{3}{|c|}{ OTTER_23 } & \multicolumn{3}{|c|}{ OTTER_22 } & \multicolumn{3}{|c|}{ OTTER_16 } & \multicolumn{3}{|c|}{ OTTER_3m } & \multicolumn{3}{|c|}{ OTTER_2 } & \multicolumn{3}{|c|}{ OTTER_JT } & \multicolumn{3}{|c|}{ OTTER_1A } \\
\hline & May & Jul & Oct & May & Jul & Oct & May & Jul & Oct & May & Jul & Oct & May & Jul & Oct & May & Jul & Oct & May & Jul & Oct \\
\hline Water Temp @ & na & na & 11.3 & 25.6 & 29.3 & 9.4 & 19.2 & 21.5 & 7.8 & na & na & na & 22.6 & 20.3 & 8.7 & 21.7 & 17.1 & 6.5 & 11.8 & 26.3 & 7 \\
\hline TDS (ppm) & na & na & $>2,000$ & 1840 & 1865 & 1155 & 1701 & $>2,000$ & 1085 & na & na & na & 1842 & $>2,000$ & 1099 & 1563 & 1469 & 1000 & $>2,000$ & $>2,000$ & 1278 \\
\hline Conductivity $(\mu \mathrm{s} / \mathrm{cm})$ & na & na & $>4,000$ & 3671 & 3733 & 2312 & 3410 & $>4,000$ & 2173 & na & na & na & 3668 & $>4,000$ & 2199 & 3126 & 2935 & 2000 & $>4,000$ & $>4,000$ & 2664 \\
\hline pH & na & na & 8.4 & 8.5 & 8.4 & 8.7 & 8.3 & 8.5 & 8.6 & na & na & na & 8.35 & 8.6 & 8.7 & 8.2 & 8.4 & 8.5 & 8.05 & 8.5 & 8.03 \\
\hline PFC & FAR & FAR & FAR & PFC & PFC & PFC & PFC & PFC & PFC & NF & NF & NF & FAR & FAR & FAR & PFC & PFC & PFC & FARd & FARd & FARi \\
\hline BLM HBI & 16 & 16 & 16 & 19 & 21 & 20 & 19 & 23 & 21 & 12 & 12 & 12 & 17 & 17 & 18 & 20 & 22 & 20 & 15 & 12 & 17 \\
\hline Avg wetted width (m) & 0.0 & 0.0 & 0.2 & 5.7 & 6.5 & 5.9 & 10.8 & 10.7 & 11.4 & na & na & na & 1.6 & 1.5 & 1.2 & 4.5 & 4.3 & 4.8 & 2.7 & 2.4 & 2.1 \\
\hline Avg Left CHD (cm) & 0 & 0 & 2 & 34 & 42 & 39 & 77 & 70 & 78 & na & na & na & 25 & 30 & 25 & 32 & 27 & 55 & 30 & 29 & 32 \\
\hline Avg Center CHD (cm) & 0 & 0 & 2 & 43 & 46 & 46 & 91 & 85 & 90 & na & na & na & 40 & 42 & 32 & 34 & 35 & 59 & 36 & 37 & 40 \\
\hline Avg Right CHD (cm) & 0 & 0 & 2 & 30 & 35 & 32 & 78 & 65 & 75 & na & na & na & 25 & 25 & 20 & 26 & 26 & 48 & 24 & 30 & 27 \\
\hline$\%$ Fines in Reach & 90 & 100 & 95 & 83 & 88 & 88 & 84 & 88 & 91 & 100 & 100 & 100 & 45 & 50 & 45 & 60 & 65 & 54 & 100 & 98 & 97 \\
\hline$\%$ Gravel Reach & 5 & 0 & 3 & 7 & 8 & 6 & 6 & 7 & 7 & 0 & 0 & 0 & 40 & 35 & 40 & 36 & 28 & 34 & 0 & 1 & 2 \\
\hline$\%$ Cobble Reach & 5 & 0 & 2 & 10 & 4 & 6 & 10 & 5 & 5 & 0 & 0 & 0 & 15 & 15 & 15 & 4 & 7 & 12 & 0 & 1 & 1 \\
\hline Livestock Use (CPI) & 28 & 15 & 56 & 20 & 18 & 10 & 35 & 0 & 8 & 42 & 50 & 30 & 5 & 12 & 5 & 22 & 0 & 12 & 64 & 35 & 25 \\
\hline Avg. Riparian Shade & 0 & 5 & 0 & 0 & 10 & 0 & 10 & 20 & 10 & 10 & 40 & 20 & 10 & 40 & 20 & 10 & 30 & 10 & 10 & 40 & 20 \\
\hline
\end{tabular}

